(الزهن في الدين وتطبيقاته القضائية)

$$
\text { إعداد }
$$

د/عبد العزيز بن ناصر بن عبد العزيز التميمي

الأستاذ المساعد في قسم الفقه المقارن

بالمعهد العالي للقضاء 
- rIrA - 
(الزمن في الدين وتطبيقاته القضائية)

عبد العزيز بن ناصر بن عبد العزيز التميمي قسم الفقه المقارن ، المعهد العالي للقضاء ، المملكة العربية السعودية. Analtmimi@imamu.edu.sa: البريد الإكتروني

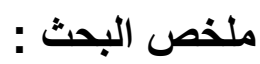
الزمن عنصر مهم ومؤثر في الدين من حيث أحكامه الفقهية وتطبيقاته القضائية. لذلك ،

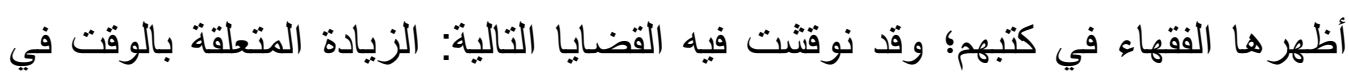

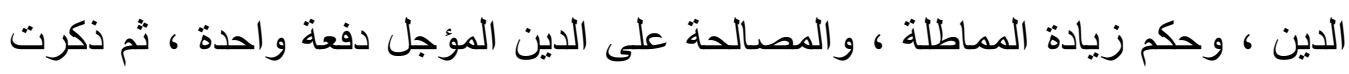

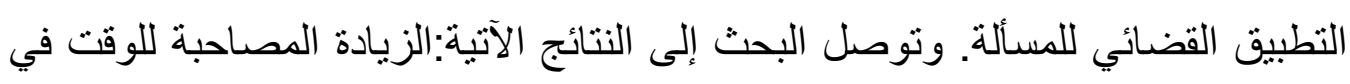

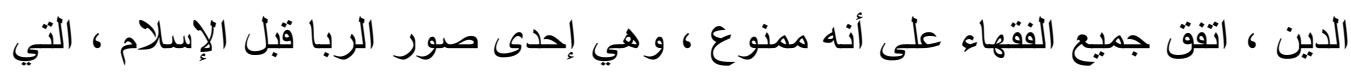

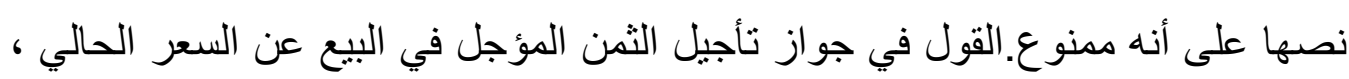

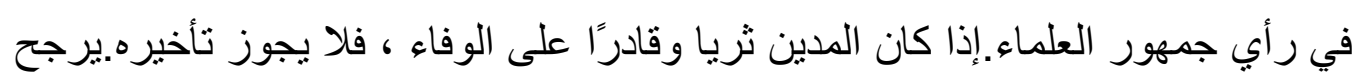

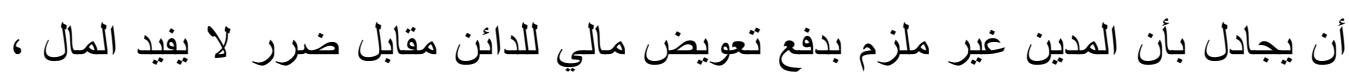

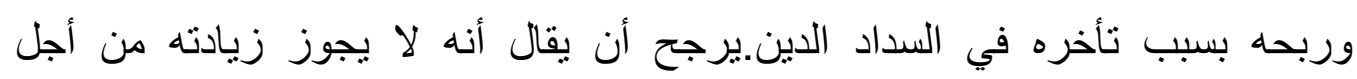

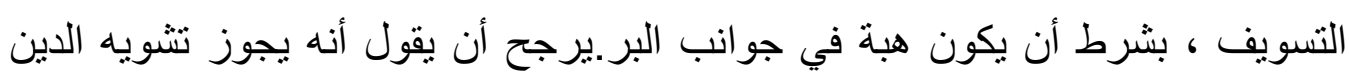

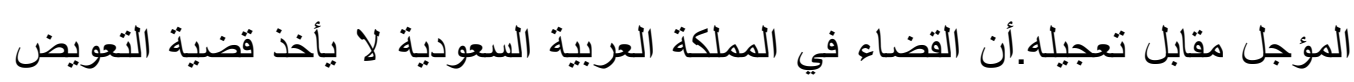

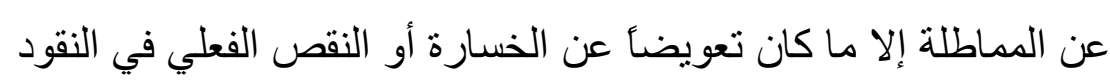
الكلمات المفتاحية: الوقت، الديّن ، تطبيقاته القضائية ، الربا ، الدين المؤجل. 
(Time in Religion and its Judicial Applications)

\section{Abdulaziz bin Nasser bin Abdulaziz Al-Tamimi \\ Department of Comparative Jurisprudence,Higher Judicial Institute, Kingdom of Saudi Arabia.}

\section{E-mail: Analtmimi@imamu.edu.sa}

\section{Abstract:}

Time is an important and influencing component of debt in terms of its jurisprudential rulings and its judicial applications. Therefore, jurists have shown it in their books; the following issues have been discussed in it: the increase related to time in debt, the ruling on increasing for procrastination, reconciliation over deferred debt at once, then I mentioned Judicial application of the matter. The research reached the following results:The increase associated with time in religion, all jurists agreed that it is forbidden, and it is one of the images of usury pre-Islamic, which the text stated that it is forbidden.Saying that it is permissible to postpone the price deferred in sales over the current price, is the view of the majority of scholars. If the debtor is rich and able to fulfill, then it is forbidden for him to delay.Is more likely to argue that the debtor is not obligated to pay a financial compensation to the creditor in exchange for the damage that misses the benefit of the money, and his profit because of his delay in paying off the debt.Is more likely to say that it is not permissible to increase for the sake of procrastination, provided that it is a 
donation in the aspects of righteousness. Is more likely to say that it is permissible to vilify the deferred debt in exchange for expediting it.That the judiciary in the Kingdom of Saudi Arabia does not take the issue of compensation for procrastination except for what was a reparation for the actual loss or decrease in the money.

Keywords: Time ,debt, its Judicial Applications, usury , deferred debt. 


\section{مقدمة}

الحمد لله الهادي إلى سبيل الرشاد، الموفق من يختاره للفقه في الدين من العباد،

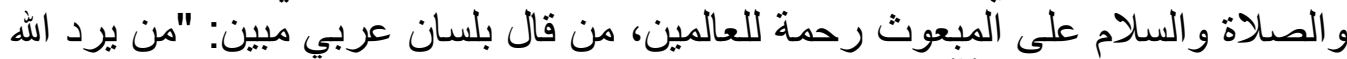

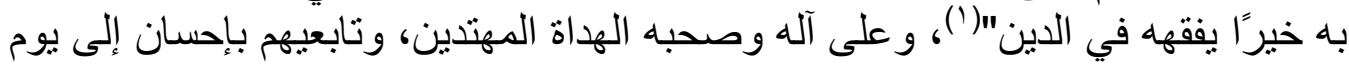

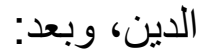

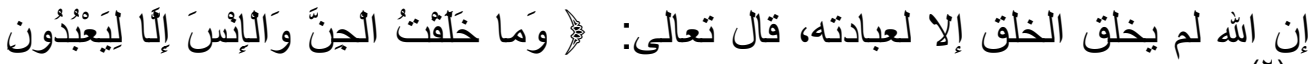
( $(r)$ 管

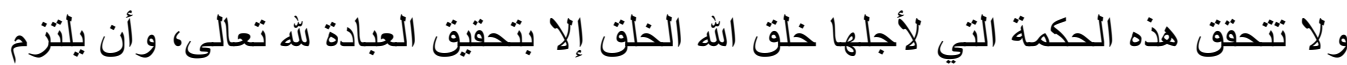

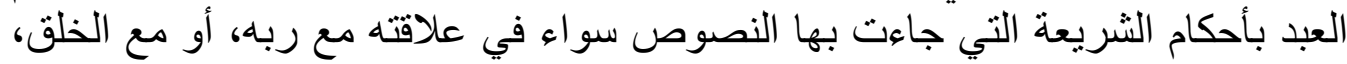

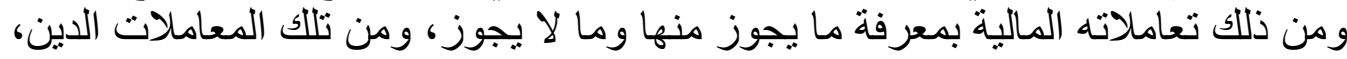

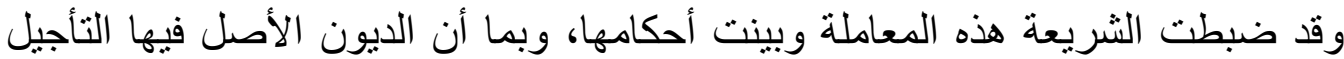

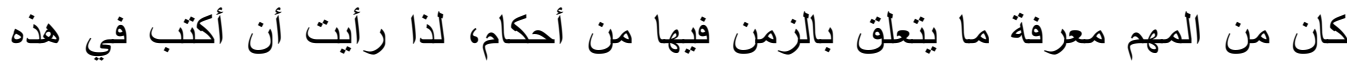
المسألة، وقد عنونت لهذا البحث بـــــ (الزمن في الدين وتطبيقاته القضائية).

\section{خطة البحث}

جعلت البحث في مقدمة، وتمهيد، وأربعة مباحث، وملاحق، وفهارس، على النحو الآتي: المقدمة: وفيها التعريف بالموضوع، وسبب اختياره، و الدر اسات السابقة، وخطة البحث.

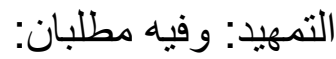
المطلب الأول: شرح مفردات عنوان البحث. المطلب الثاني: الألفاظ ذات الصلة. المبحث الأول: الزيادة المرتبطة بالزمن في الدين. المبحث الثاني: حكم الزيادة لأجل المماطلة، وفيه مطلبان: المطلب الأول: الزيادة الناثئة عن المماطلة.

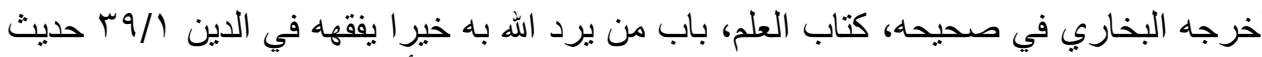

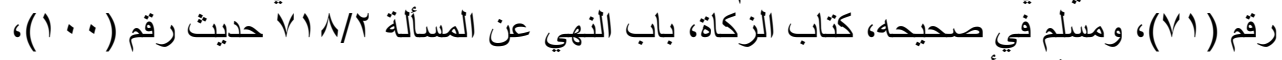

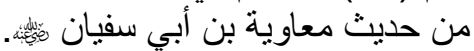

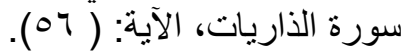


المطلب الثاني: الالنزام بزيادة بتصدق بها عند تأخر سداد الدين.

المبحث الثالث: المصالحة عن الدين المؤجل ببعضه حالاً.

المبحث الرابع: تطبيق قضائي.

الفهارس: و اشتملت على فهرس للمصادر و المر اجع، وفهرس للموضوعات.

وفي ختام هذه المقدمة أسال اله التوفيق والسداد، وأن يجعل أعمالنا خالصة

لوجهه الكريم وصلى الله وسلم على نبينا محمد. 


\section{المطلب الأول}

\section{التهربيف بـمفردات عنـوان البـثن}

(الزمن)

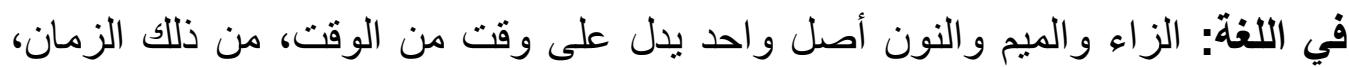

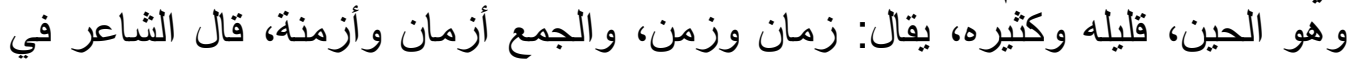

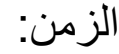

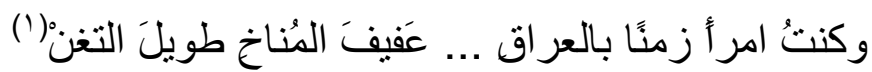
و الزمن و الزمان العصرَ، وزمن زامن: شديد، وأزمن الثنيء: طال عليه الزمان، والاسم

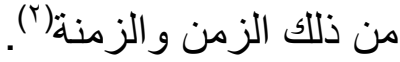

وفي الاصطلاح:

جاء في التعريفات قوله: " الزمان هو مقدار حركة الفلك الأطلس عند الحكماء، وعند

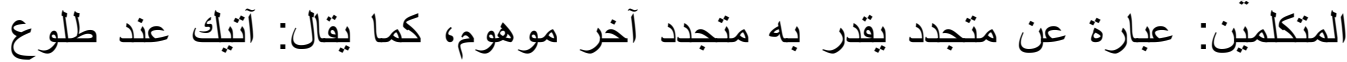
زالثمس؛ فإن طلوع الثمس معلوم ومجيئه مو هوم، فإذا قرن ذلك اللك المو هوم بذللك المعلوم

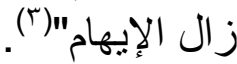

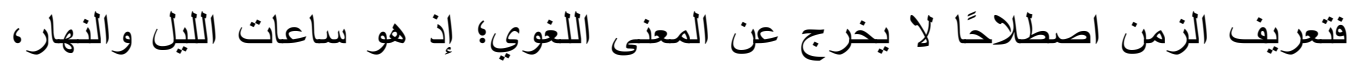

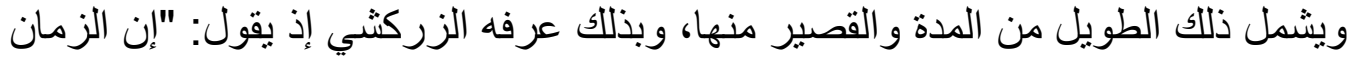

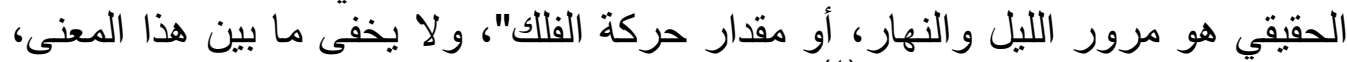
و المعنى اللغوي من ارتباط وثيق(أ).

(الاين)

في اللغة: الدال و الياء و النون أصل واحد إليه يرجع فروعه كلها، وهو جنس من الانقياد،

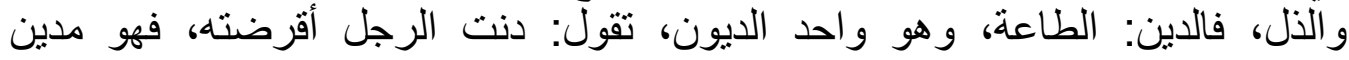

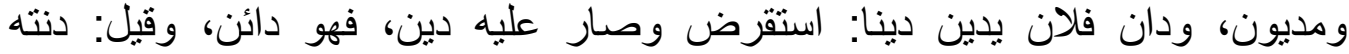
أقرضته، وأدنته استقرضته منه، ورجل دائن ومدين ومديون، الأخيرة تميمية، ومدان:

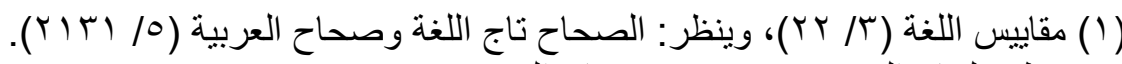

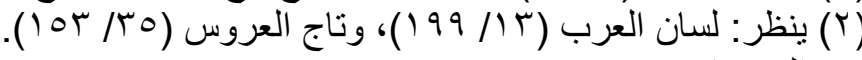

(ع) ينظر: الزمن في القرآن الكريم، إعداد: عودة عبد عودة عبد الله، ص (9) (9) بحث تكميلي استكمالكا

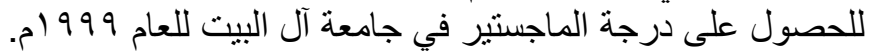


عليه الدين، وقيل: هو الذي عليه دين كثثر، ومديان إذا كان عادته أن يأخذ بالدين ويستقرض (')

وفي الاصطلاح: اختلفت تعريفات الفقهاء للدين على قولين:

القول الأول: المال الثابت في الذمة بدلا عن شيء آخر، وهذا ما ذهب إليه جمهور

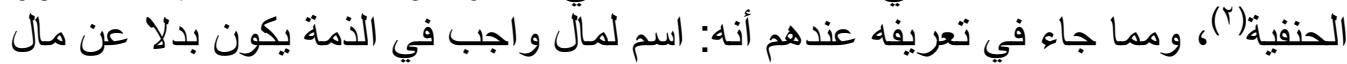

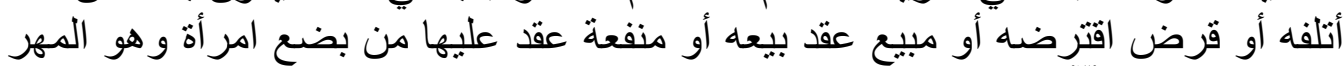

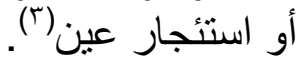

القول الثاني: المال الثابت في الذمة، وهو قول الجمهور(؛).

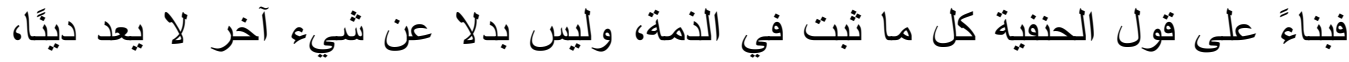
كالزكاة، وقد نصوا على ذللك، قال الثلبي: "وليس الزكاة بدلا عن شيء آخر، فلا يكون دينا")(')

أما على قول الجمهور، فكل ثابت في الذمة سواء كان بدلا عن شيء آخر، كثمن البيع،

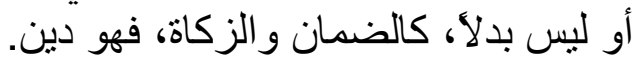

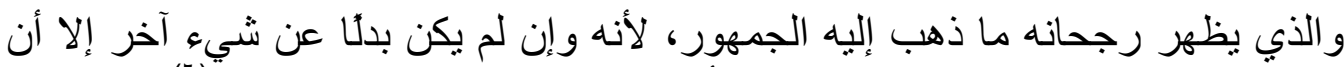

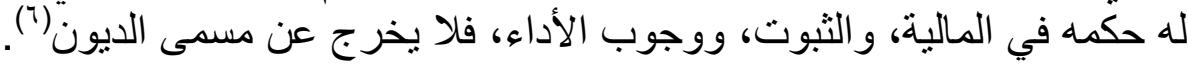

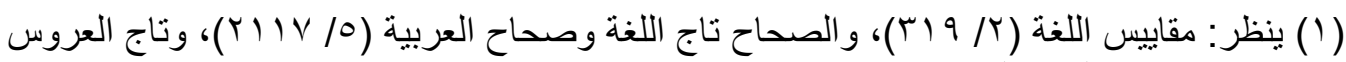

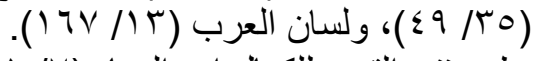

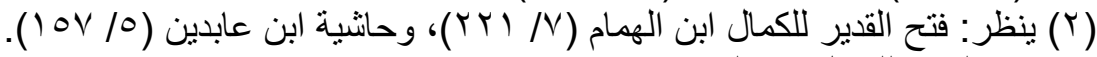

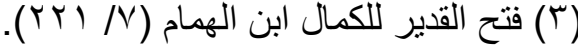

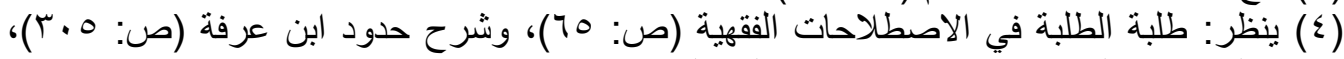

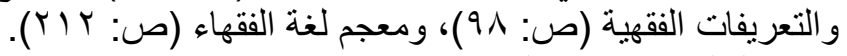

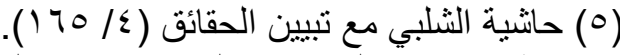

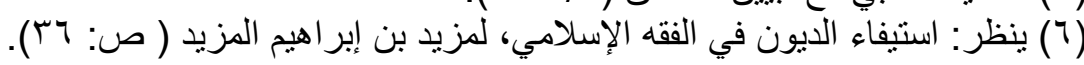




\section{المطلب الثنانبي}

\section{الألفاظ ذات الملة}

(القرض)

في اللغة: القاف والراء والضاد أصل صحيح، وهو يدل على القطع، يقال: قرضت

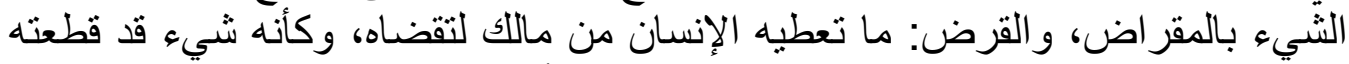

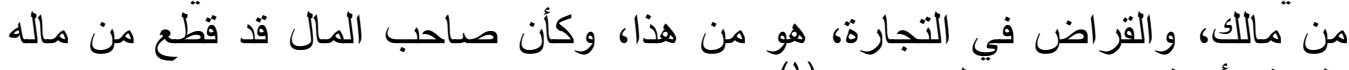

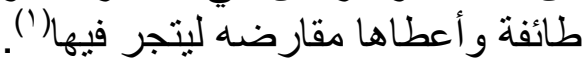

وقال الليث: كل أمر يتجازى به الناس فيما بينهم فهو من القروض(؟). وفي الاصطلاح: تعددت تعريفاته، وعند الحنابلة هو: دفع مال إلى الغير لينتفع به ويرد بدله" (r)

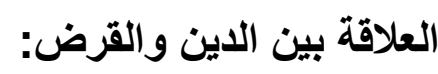

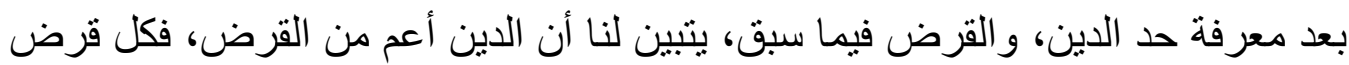

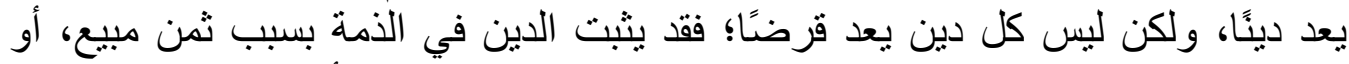

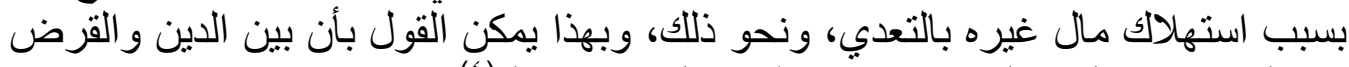

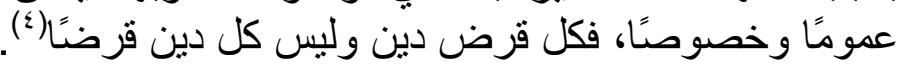

(السلف)

في اللغة: السين و اللام و الفاء أصل يدل على تقام وسبق. من ذلك السلف: الذين مضوا.

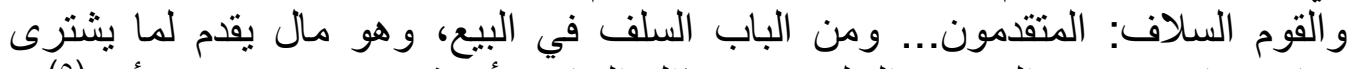

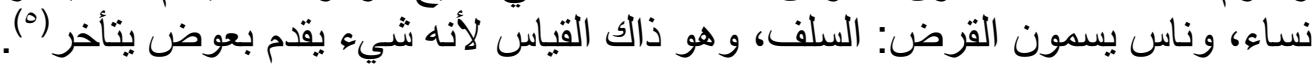
وفي الاصطلاح: يرد على وجهين:

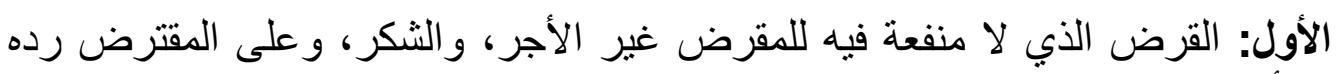
كما أخذه، و العرب تسمي القرض سلفًا.

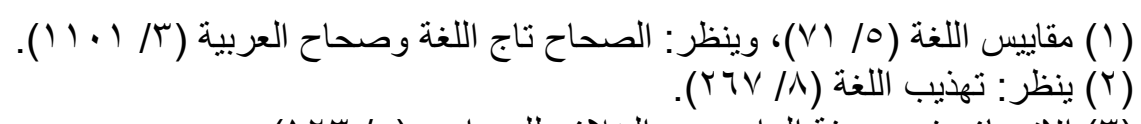

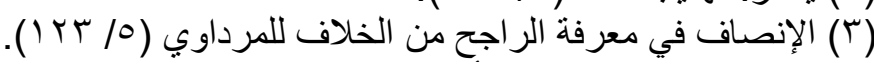

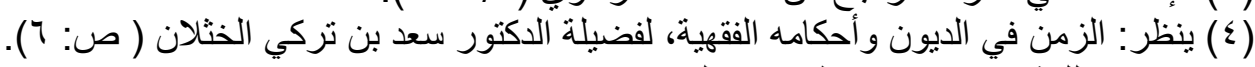

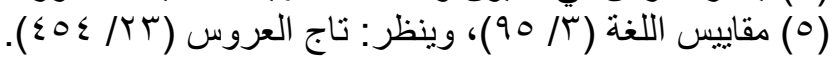


والثاني: هو أن يعطي مالّا في سلعة إلى أجل معلوم بزيادة في السعر الموجود عند

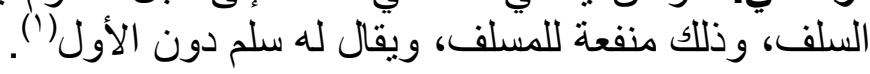

\section{العلاقة بين السلف والدين:}

السلف نوع من الدين، و عليه فالدين أعم من السلف، قال ابن عثيمين: الدين عند الفقهاء

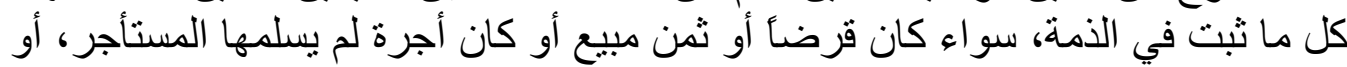

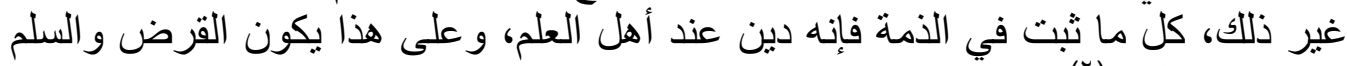

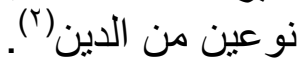

(العين)

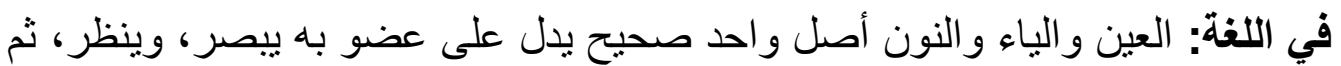

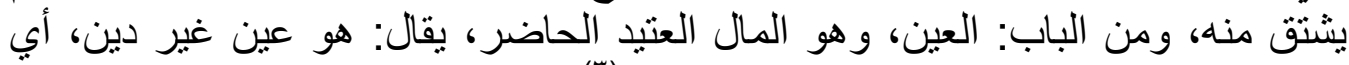

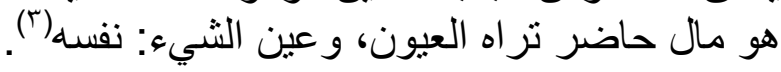

وفي الاصطلاح: تعددت تعريفات الفقهاء للعين، ومما جاء في ذلك أن العين:

-

- - الثيء المعين المشخص كبيث، بلنين، وحصان، وكرسي، وصبرة حنطة، وصبرة

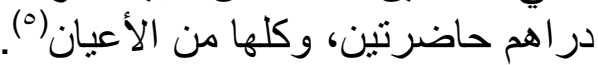

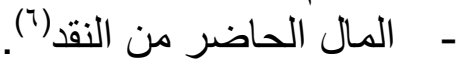

العلاقة بين العين والدين:

مما سبق يتبين أن العلاقة بين العين، والدين علاقة تضداد؛ فالعين تكون حاضرة،

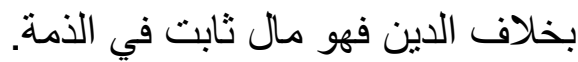

(1) ينظر: النهاية في غريب الحديث والأثر (r/ • (9)، وانيس الفقهاء في تعريفات الألفاظ المتداولة

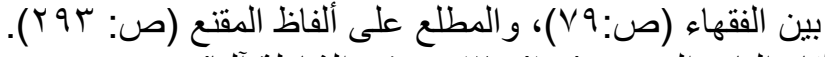

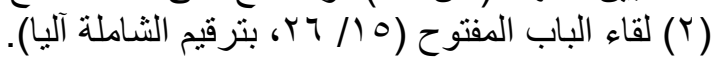

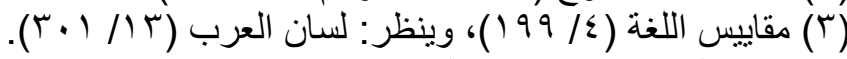

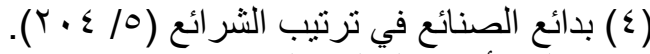

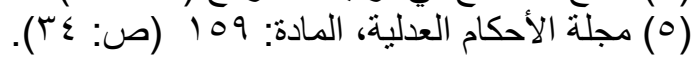

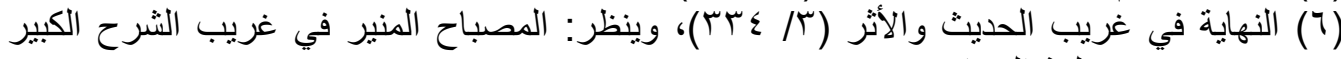
( ) ( 


\section{المبحث الأول}

\section{الزيادة المرتبطة بالزمن في الدين}

صورة المسألة: أن يبيع الرجل البيع إلى أجل مسمى، فإذا حلَّ الأجل، ولم يكن عند

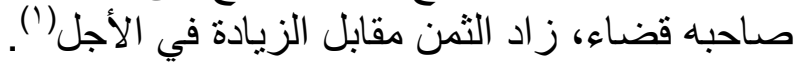

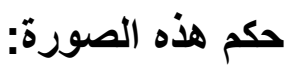

أجمع الفقهاء على تحريم هذه الصورة من المعاملات، وهي إحدى صور ربا الجاهلية

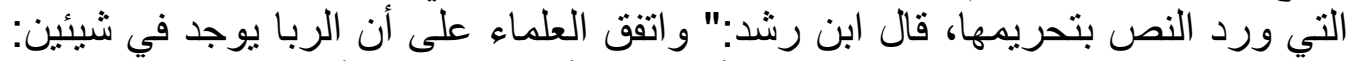

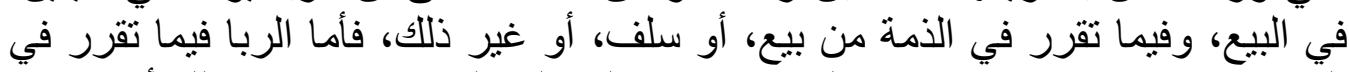

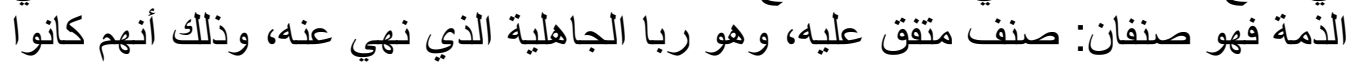

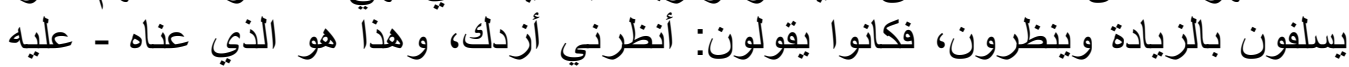

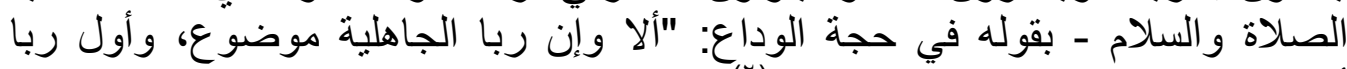

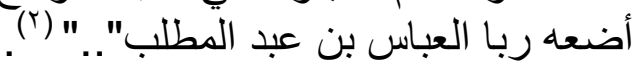

الأدلة: وردت أدلة على تحريم هذا النوع من المعاملات منها:

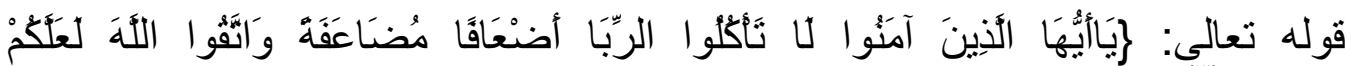

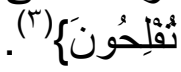

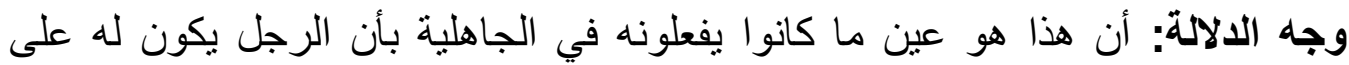

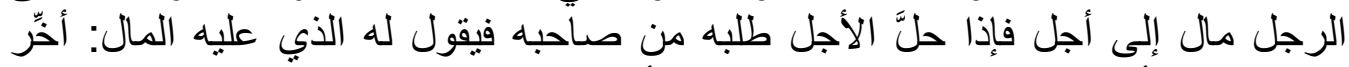

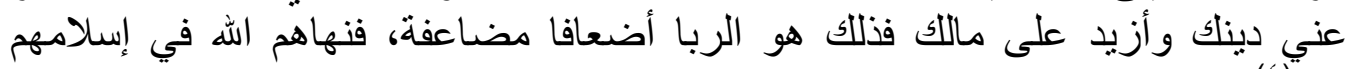

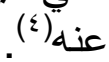

(1) أحكام الزيادة في غير العبادات، لمحمد العيد // . (1، وينظر : الزمن في الديون وأحكامه الفقهية

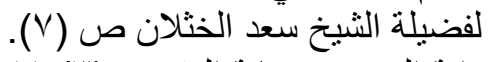

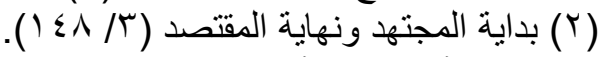

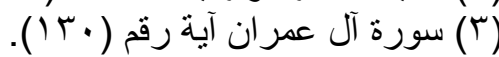

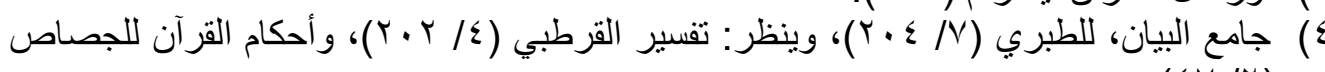




\section{ومن السنة قوله}

وجه الدلالة: أن الربا الكامل، إنما هو في النسيئة، وهي الزيادة في الثمن لأجل تأجيل الدين(r)

\section{الفرق بين هذه الصورة وبين بيع التقسيط:}

سبب اير ادي لهذه المسألة هو وجود العلاقة بين التأجيل، و التقسيط()، مع اختلاف الحكم

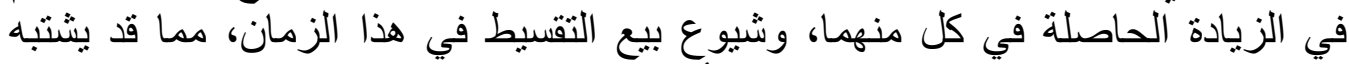

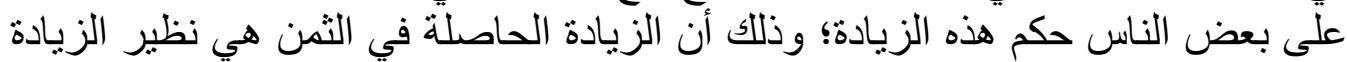
في الأجل، فلو بيعت السلعة حالة نقص في ثمنها.

\section{فهل تكون هذه المعاملة من صور الربا المحرم؟}

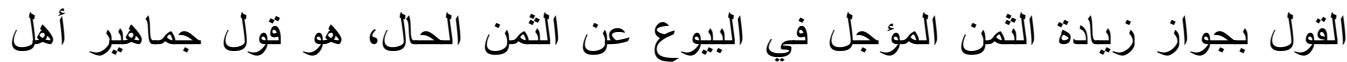

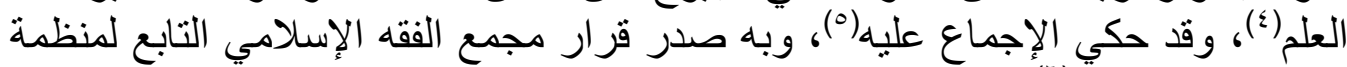

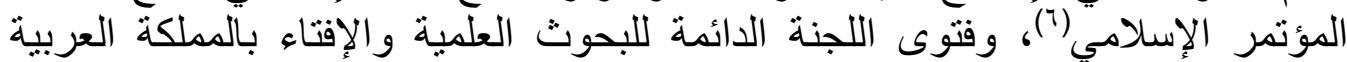

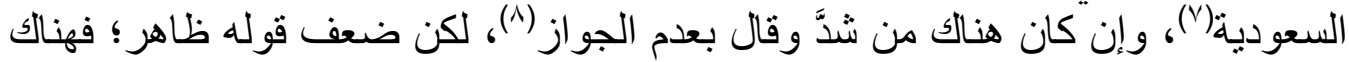
فرق بين الصورنين.

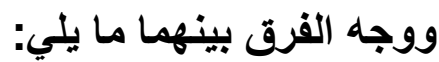

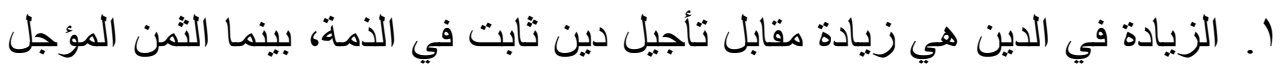

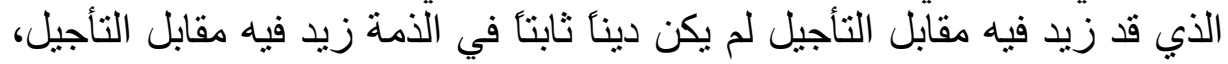

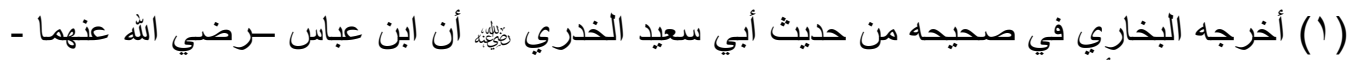

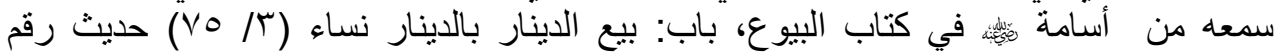

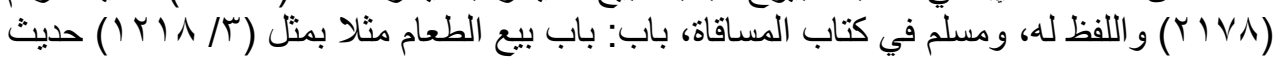

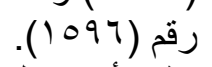

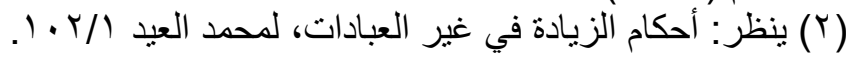

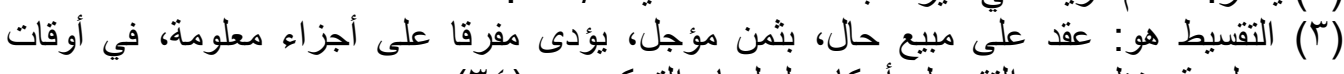

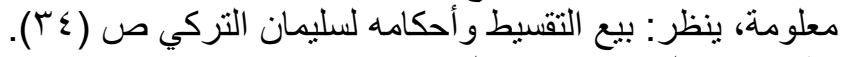

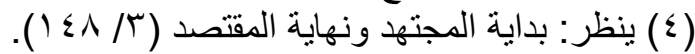

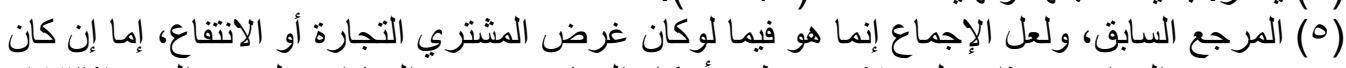

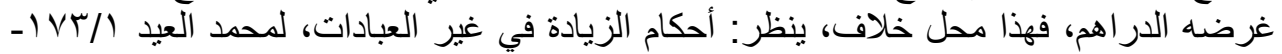
IV 1

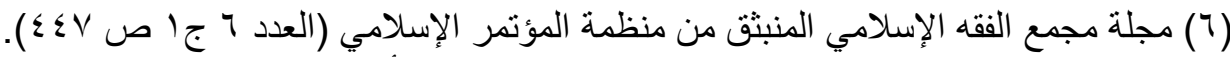

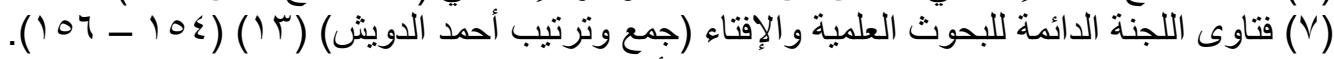

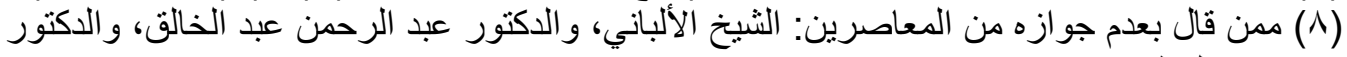


و إنما هو ثمن مبيع ثبت في ذمة المشتري مؤجالا ابتداءً، كما أن المبيع والثمن

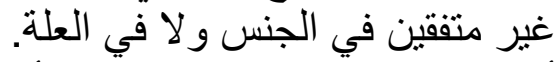

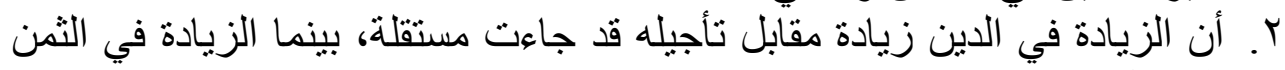

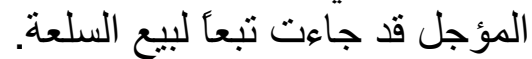

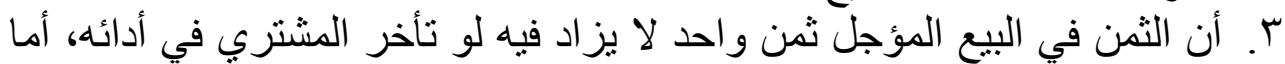

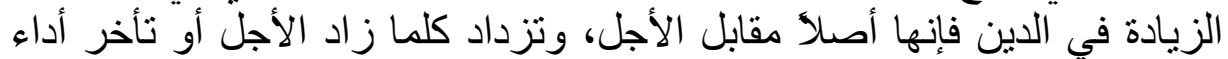
الدين.

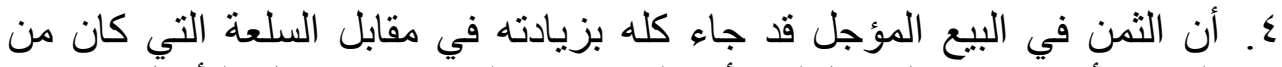

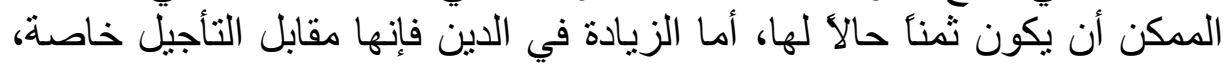

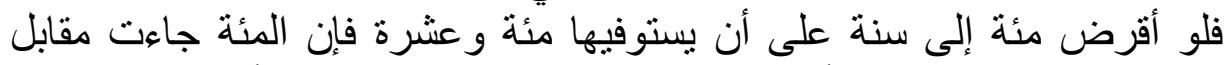

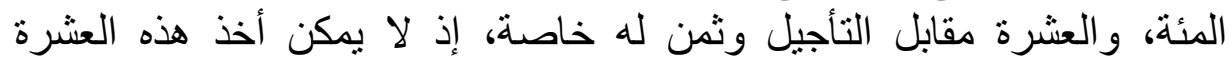
الزائدة بغير التأجيل البتة.

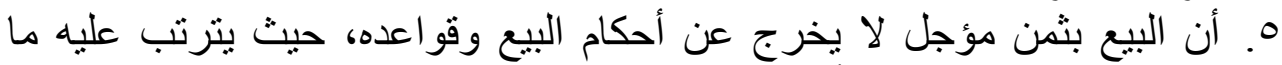

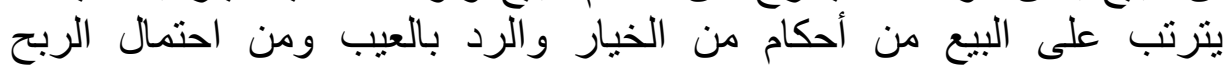

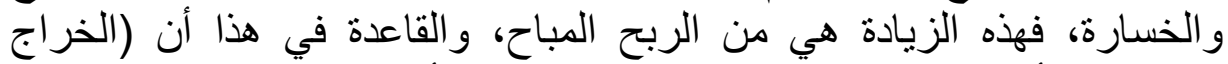

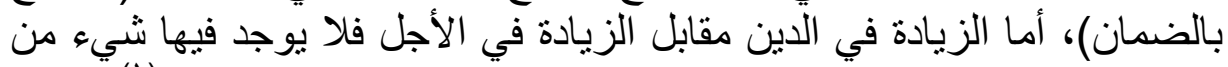

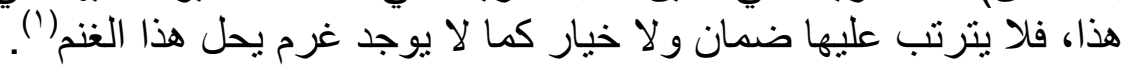




\section{البمش الثاني \\ مكم الزيادة لأجل المهاطلة \\ المطلب الأول}

\section{الزيادة الناشئة عن المماطلة}

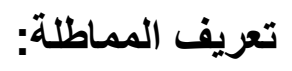

في اللغة: مأخوذة من المطل، فالميم والطاء و اللام أصل صحيح يدل على مد الثيء ولثيء

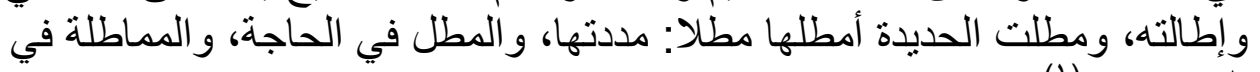

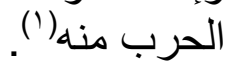

و المماطلة: التسويف بالدين، مطله حقه، وبه بمطله مطلا، و امتطله، وماطله به مماطلة ومطالا، ورجل مطول ومطال(؟).

وفي الاصطلاح: تأخيره أداء الدين من وقت إلى آخر، لغير عذر، مع الطلب(؟).

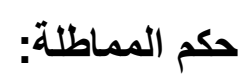

المدين إن كان غنيًا قادرًا على الوفاء، فإنه يحرم عليه المماطلة، وقد دل على ذلك الكتاب

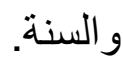

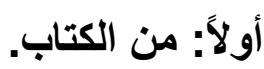

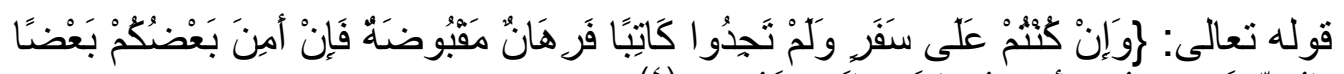

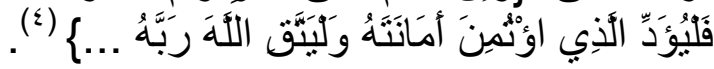

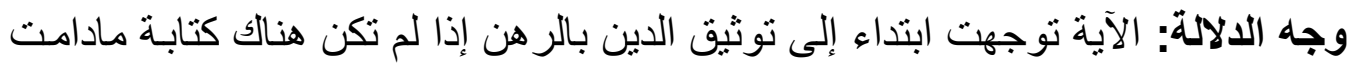

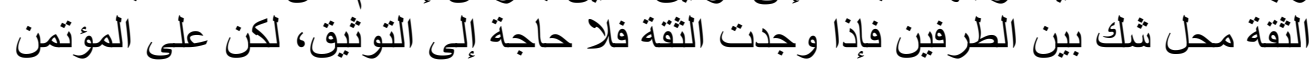

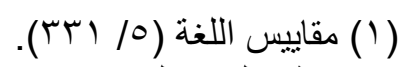

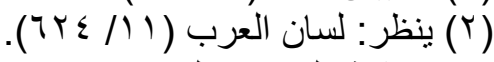

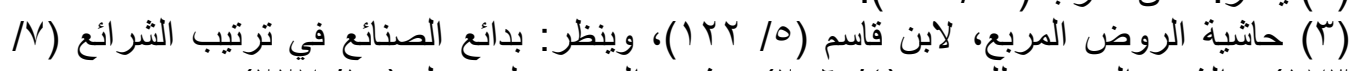

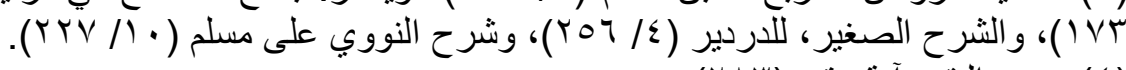


أن يبادر إلى رد الأمانة، و هي الدين، أو الحق('). ثنانياً: من السنة. عن أبي هريرة رضي الله عنه: أن رسول الله على ملّيء فليتبع "(r).

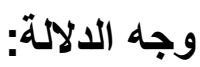

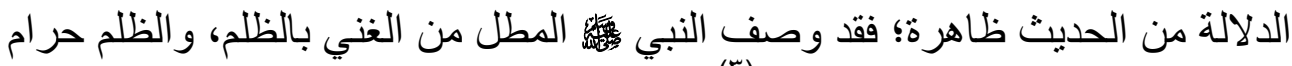

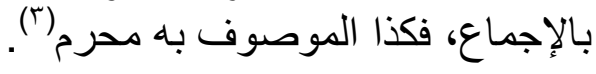

\section{حكم الزيادة في الاين الناشئة عن ضرر المماطلة.}

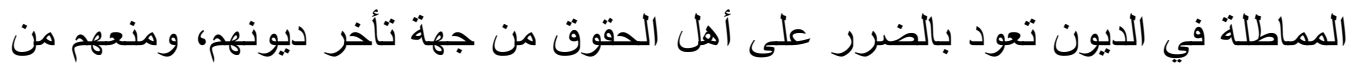

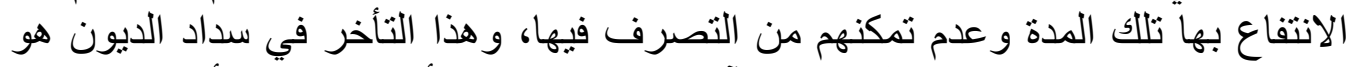

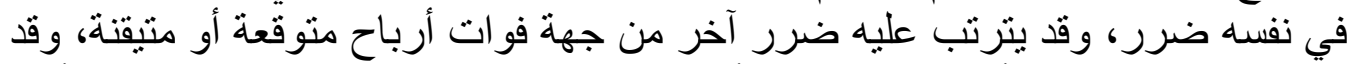

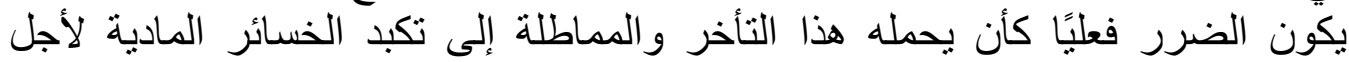

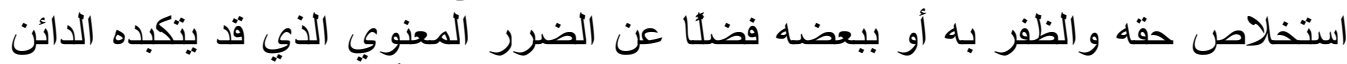

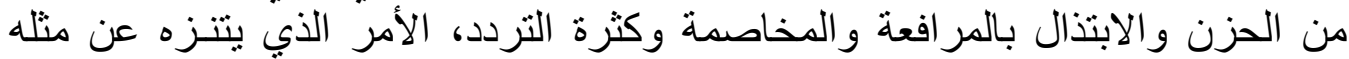

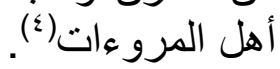

\section{تحرير محل النزاع: - ت ت}

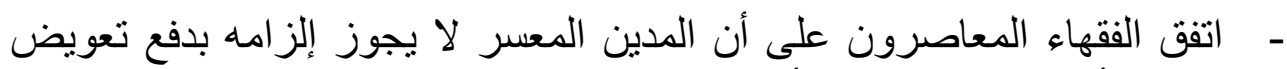

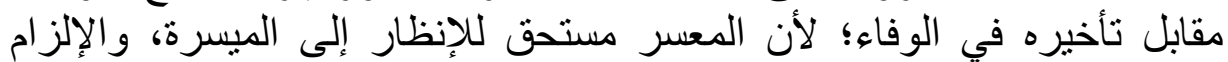

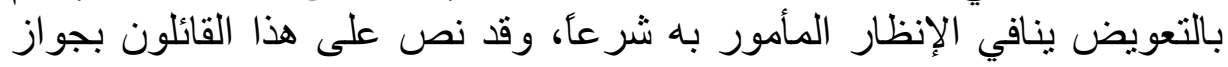
التعويض المالي عن ضرر مماطلة المدين.

( (1) ينظر: المسؤولية الجنائية للمدين المماطل في الثريعة والقانون، للباحث عبدالرحمن اللحيدان ص

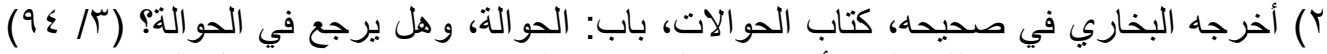

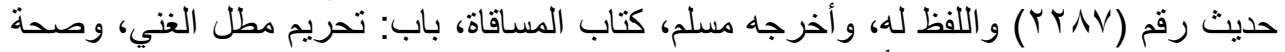

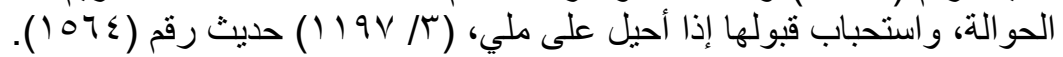

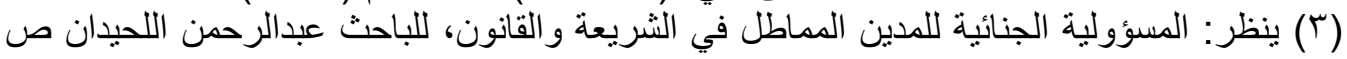
(ا) التعويض عن الأضرار المترتبة على المماطلة في الديون، للاكتور سلمان بن صالح الدخيل بحث

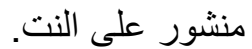




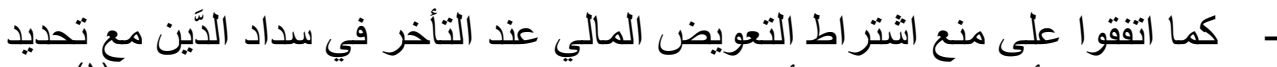

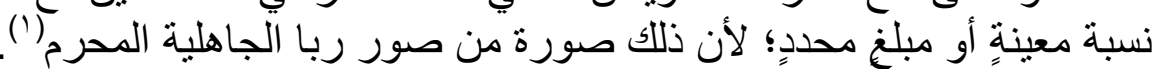

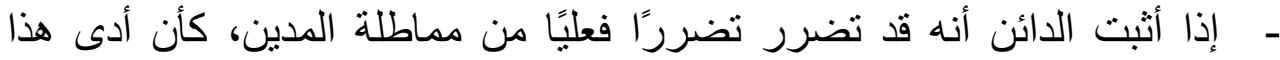

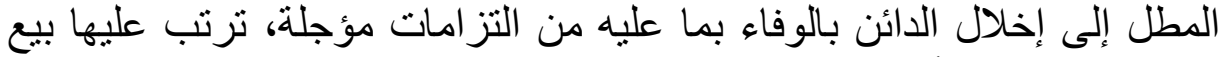

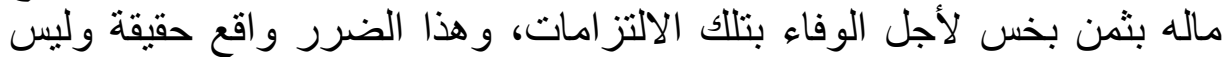

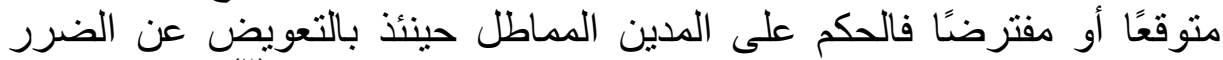

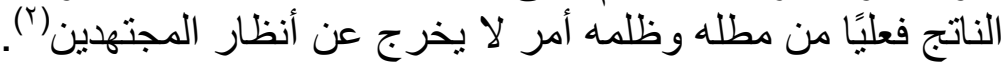

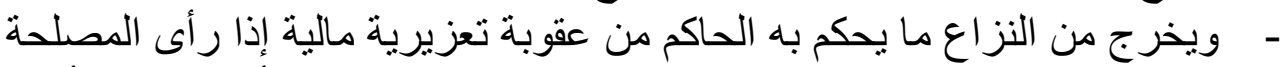

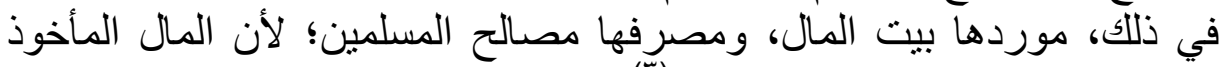

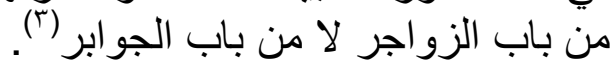

فينحصر الخلاف فيما إذا ماطل المدين في أداء دينه المستحق للادئن، وحبس المال لديه

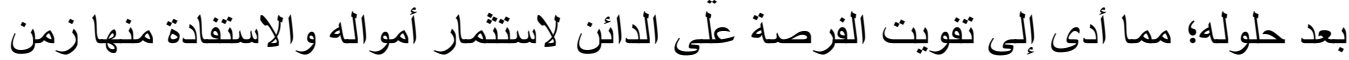

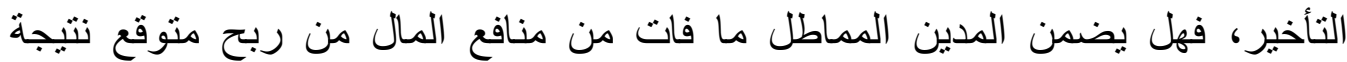

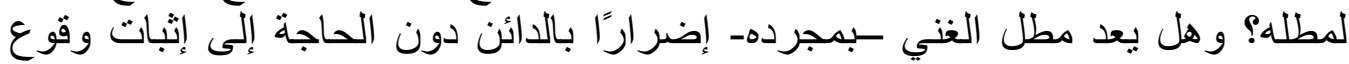

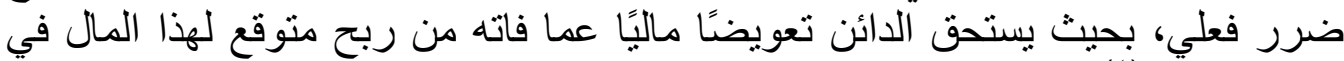
زمن التأخير؟(؟) فئ)

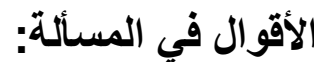

اختلف العلماء المعاصرون في المسألة على قولين:

القول الأول: عدم جواز إلزام المدين المماطل القادر على الوفاء بتعويض مالي بدفعها

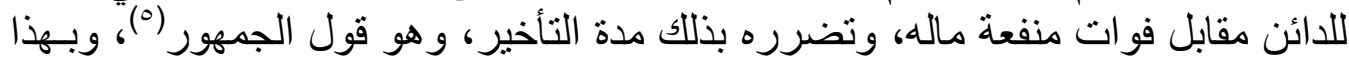

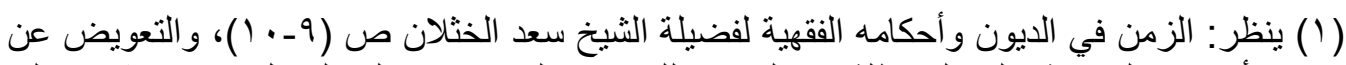
الأضرار المترتبة على المماطلة في الديون، للاكتور سلمان بن صالح الدخيل بحث منشور على النى

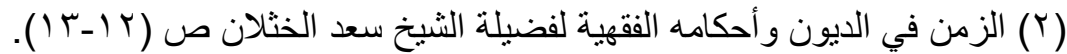

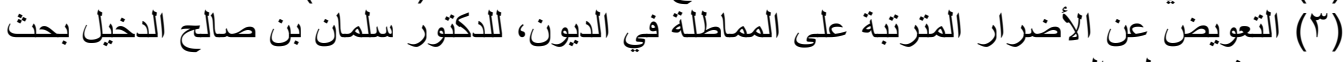

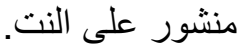

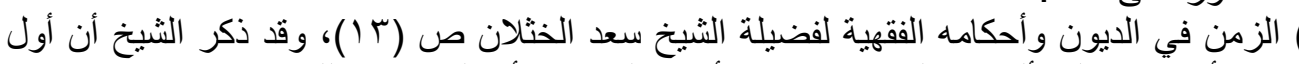

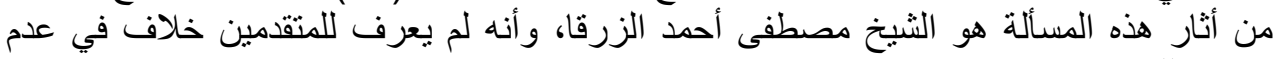
جواز ذلك. (o) نسبه فضيلة الثيخ سعد الخثلان إلى جماهير السلف والخلف، ينظر: الزمن في الديون وأحكامه 
القول صدرت قرارات المجامع الفقهية(')، والهيئات الشرعية(Y)، وهو قول جمهور

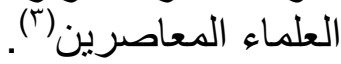
جاء في معيار المدين المماطل المعتمد من المجلس الثرعي لهيئة المحاسبة والمراجعة للمؤسسات المالية الإسلامية:

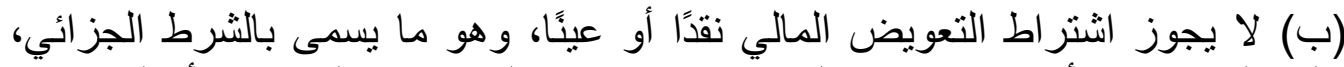

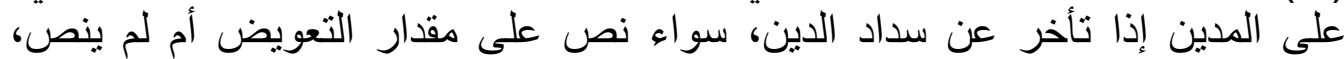
وسواء كان التعويض عن الكسب الفائت (الفرصة الضائعة) أم عن تغير قيمة العملة . (ج) لا تجوز المطالبة القضائية للمدين المماطل بالتعويض المالي نقدًا أو عينًا عن تأخير الدين(飞)

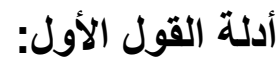
أولاً: أدلتهم من الكتاب. استدلو ا بعموم أدلة تحريم الربا، ومنها:

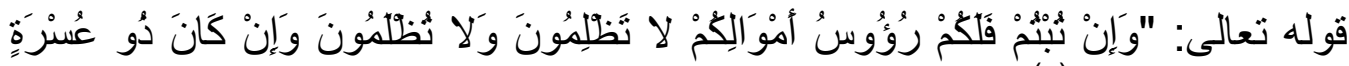

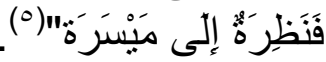

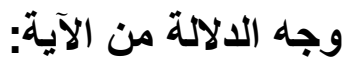

دلت الآية على تحريم الربا و إبطاله، ورد أصحاب الديون إلى رؤوس أمو الهم بلا زيادة

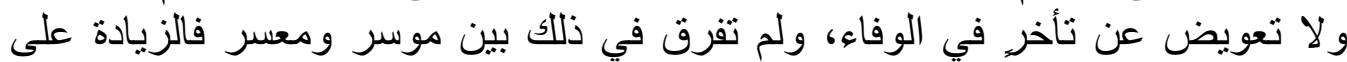

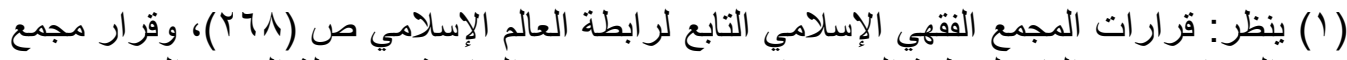

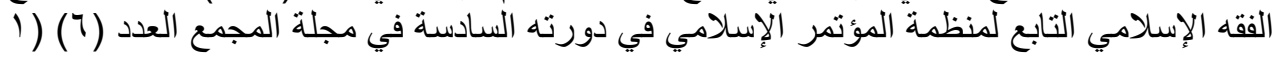
. ( $\{\leqslant \Lambda-\varepsilon \leqslant \vee /$

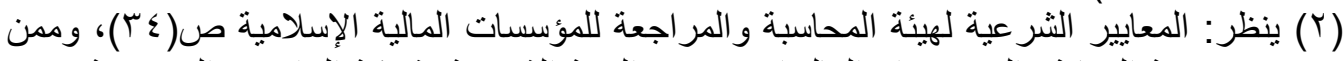

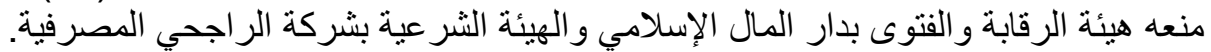

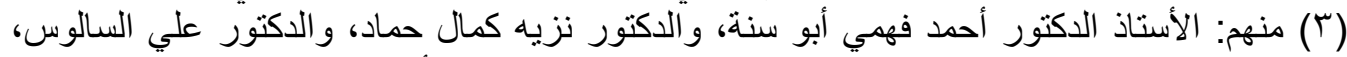

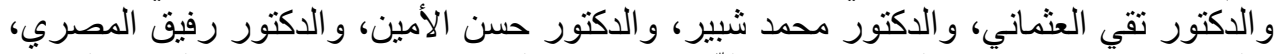

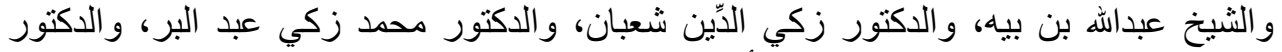

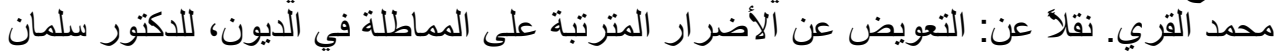

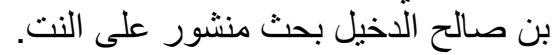

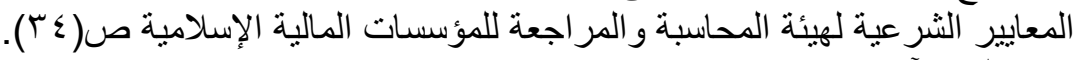


رأس المال ربا، سواء كان المدين موسرَّ أو معسرَّ، والفرق بين المعسر و الموسر إنما

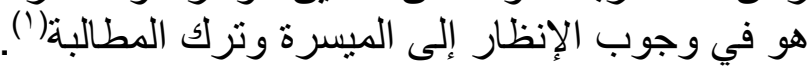

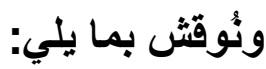

ا. عدم التسليم بأن التعويض عن ضرر المماطل من جنس الربا، وذلك أن الزيادة

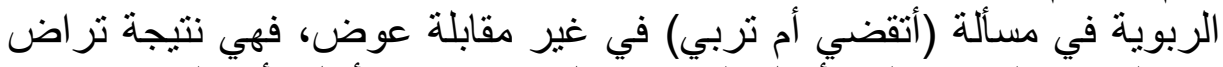

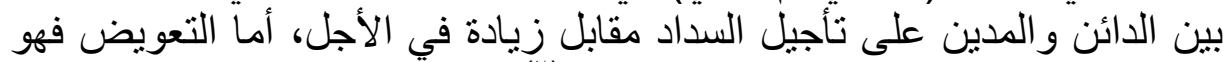

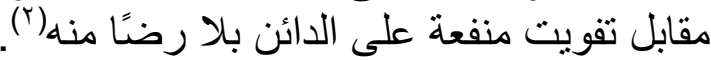

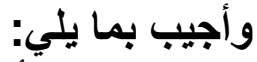

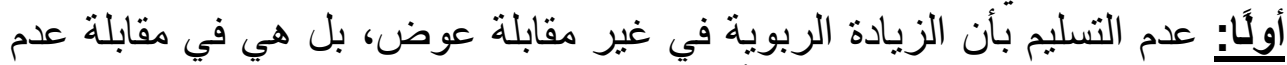

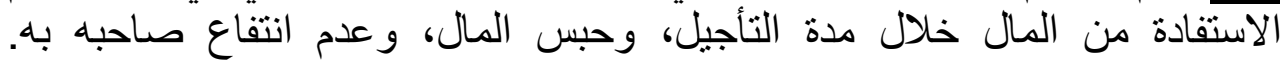

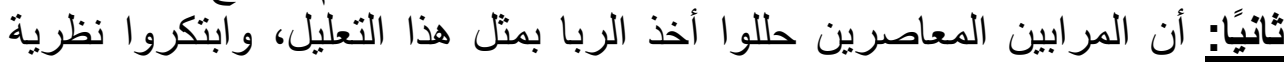

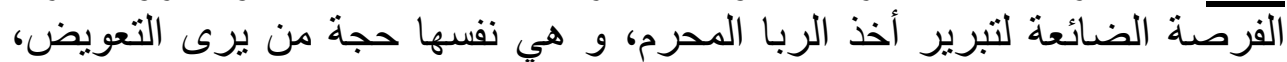

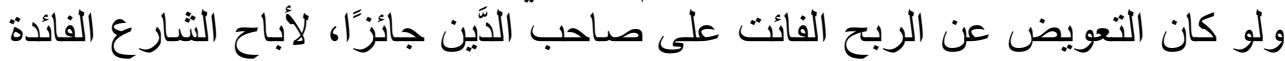

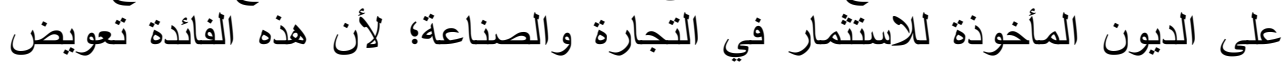

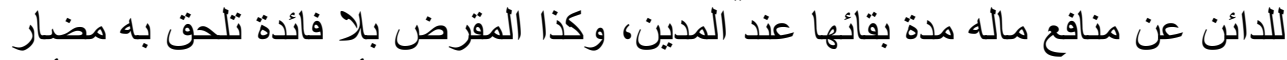

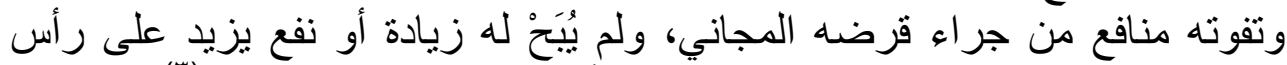

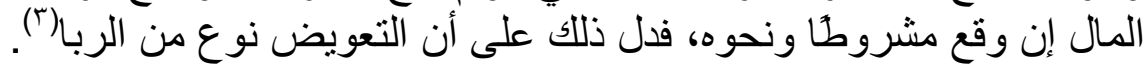

r. أن نسبة الزيادة الربوية معلومة للطرفين في بداية العقد، أما التعويض فلا بمكن فئن

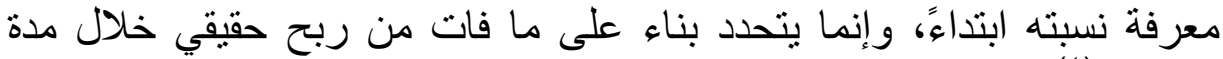

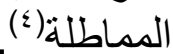

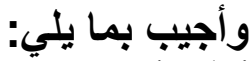

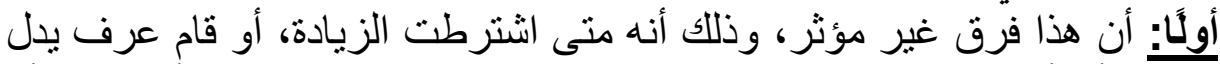

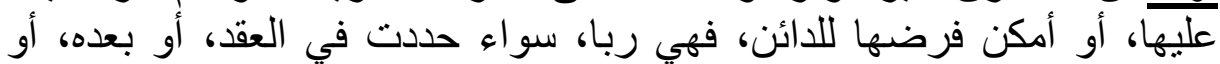

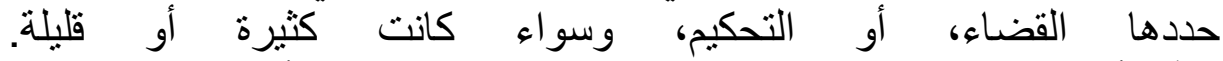

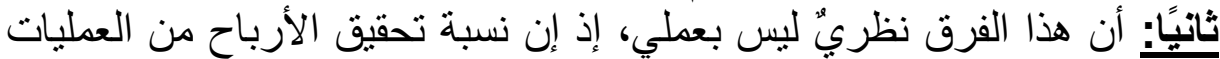

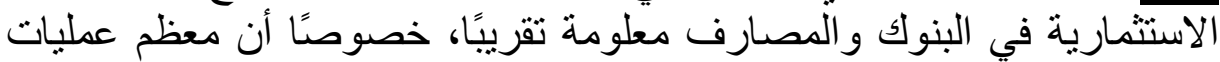

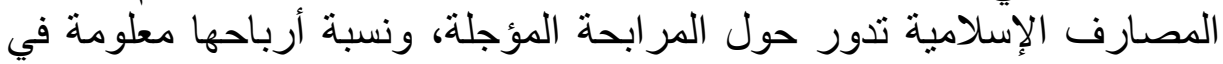

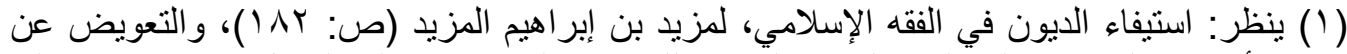

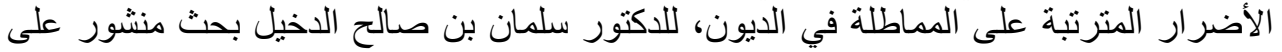

(r) ينظر : التعويض عن الأضرار المترتبة على المماطلة في الديون، للدكتور سلمان بن صالح الدخيل

$$
\begin{aligned}
& \text { بحث منشور على النت النش } \\
& \text { (r) المرجع السابق. } \\
& \text { المرجع السابق. }
\end{aligned}
$$


الجملة، فآل الأمر إلى العلم بنسبة التعويض، إذا كان التعويض راجع إلى معدل

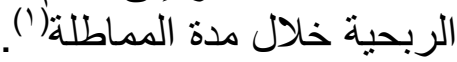

ثانياً: أدلتهم من السنة.

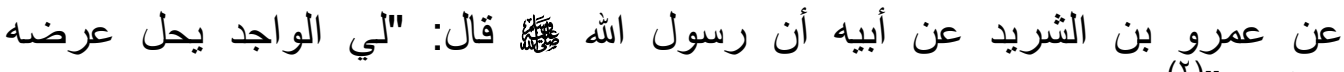
و عقوبته"(r).

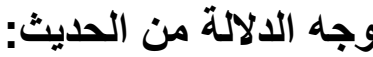

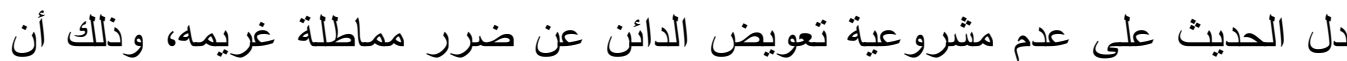
النبي

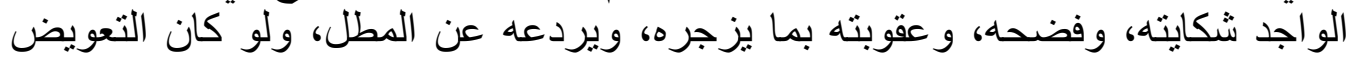

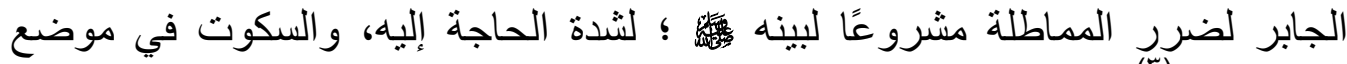

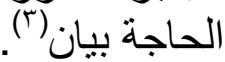

ونُوقُش:

بأن عموم لفظ العقوبة يشمل العقوبة المالية، والنصوص العامة في اعتبة اعتبار العقوبة المالية

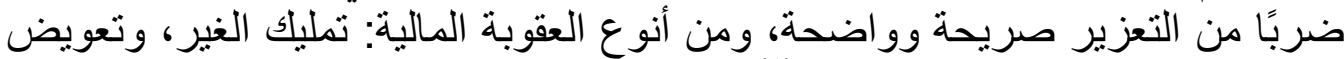

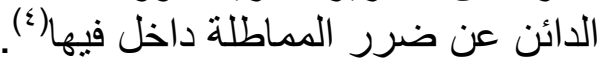

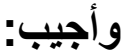

بأنه لا يصح اعتبار التعويض المالي للائن عن ضرره من باب العقوبة المالية؛ لأمرين:

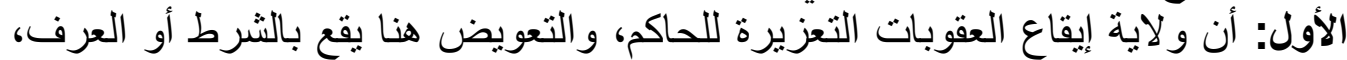

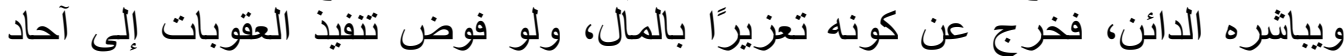

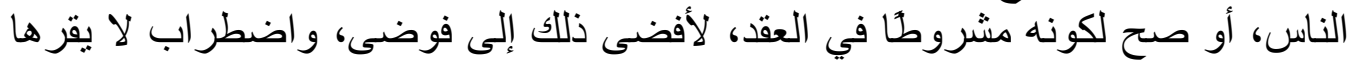

الثرع.

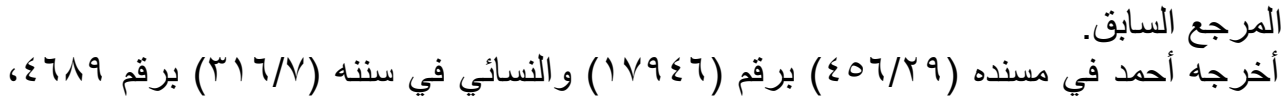

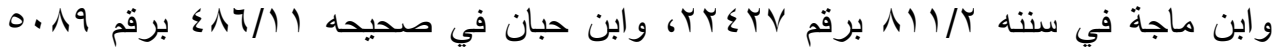

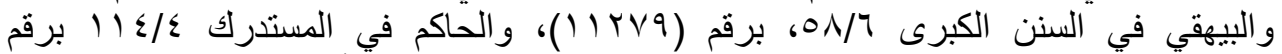

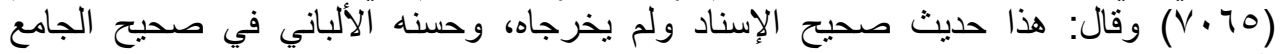

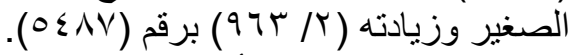

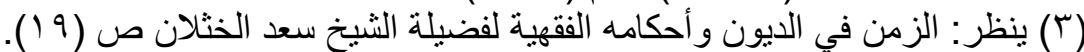

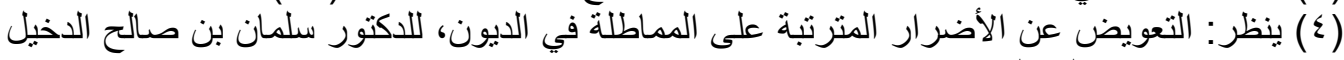


الثاني: أن المراد من العقوبة الزجر، و الردع، وليس الجبر، وإلا لوجب جبر ضرر

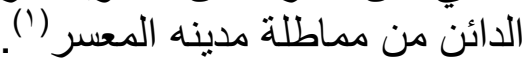

ثالثًا: أدلتهم العقلية.

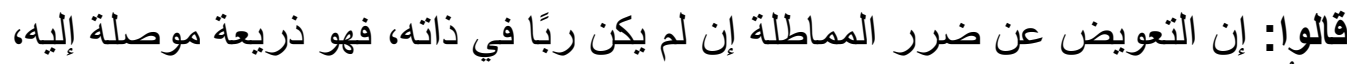

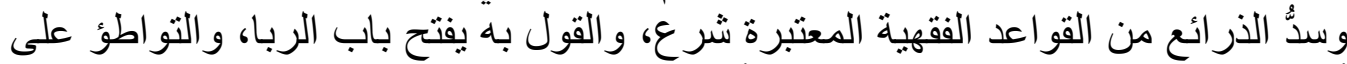

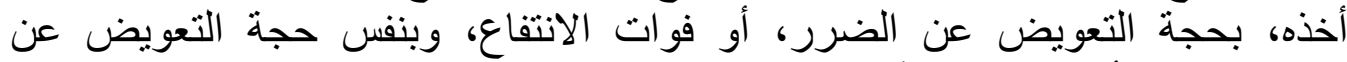

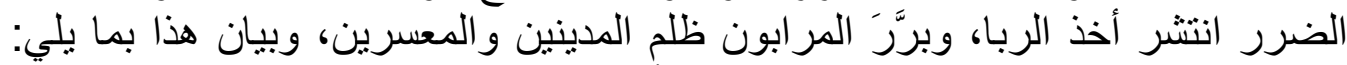

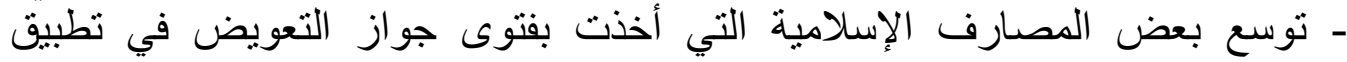

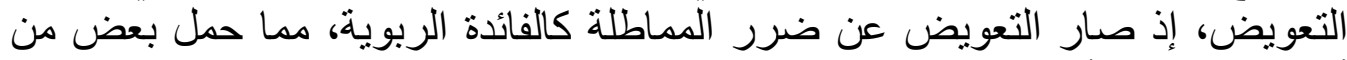

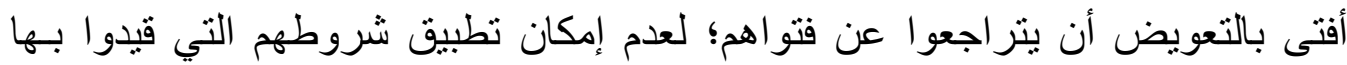

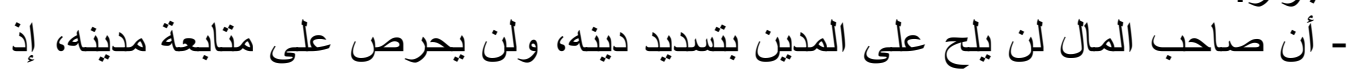

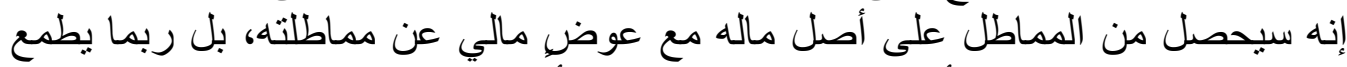

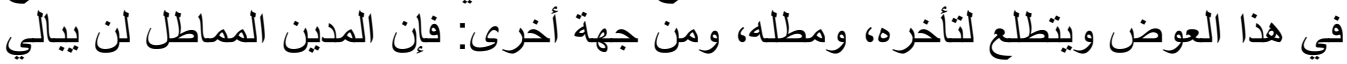

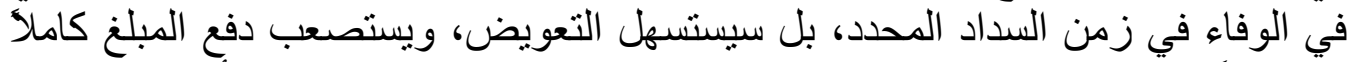

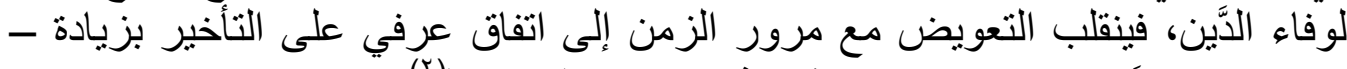

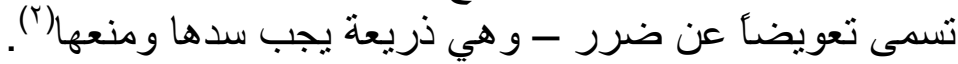

القول الثاني: جواز إلزام المدين المماطل القادر على الوفاء بتعويض مالي يدفعه

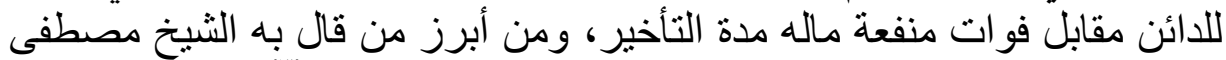

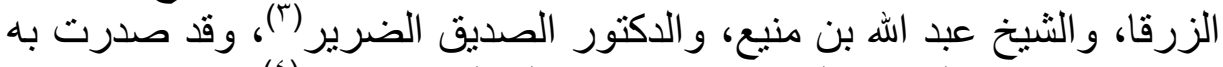

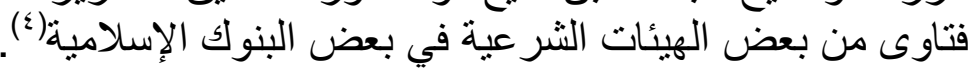

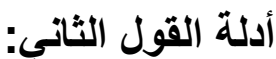
أولاً: أدلتهم من الكناب: الكتاب. الآيات الدالة على وجوب الته الوفاء بالة بالعقود، والأمانات، وتحريم أكل المال بالباطل،

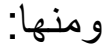

$$
\text { (Y) (Y) المرجع السابق. }
$$

(r) وممن قال با: الدكتور محمد الزحيلي و الدكتور عبد الحميد البعلي و الثنيخ محمد خاطر والدكتور عبد العزيز القصار.

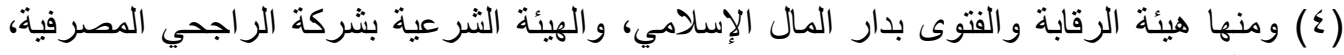

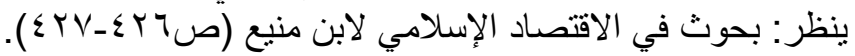




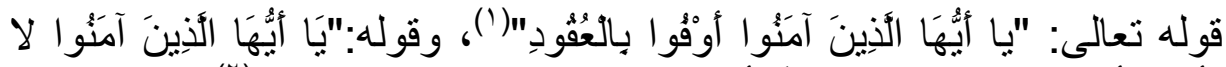

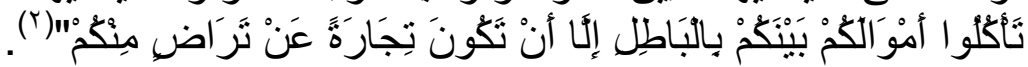
وجه الالالة من الآيتين:

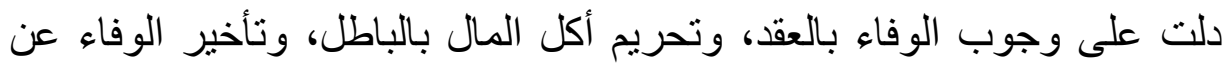

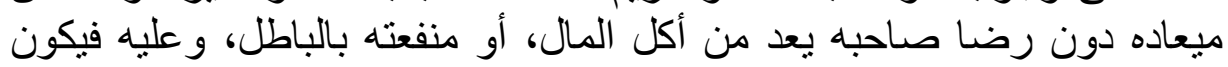

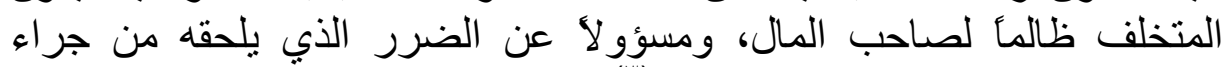

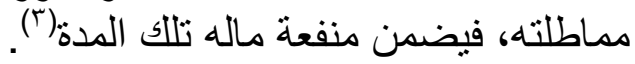

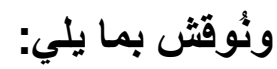

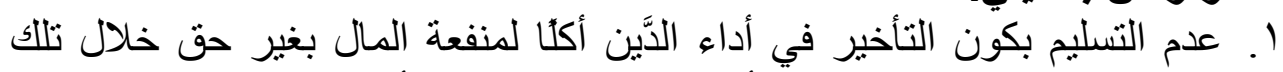

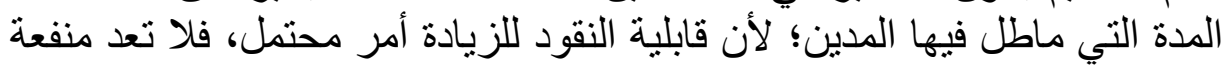

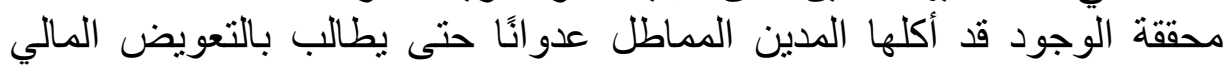
عنها. r. أن اعتبار المدين المماطل بغير عذر ظالمًا معتديًا أمر مسلم لا خلاف فيه؛ لنص

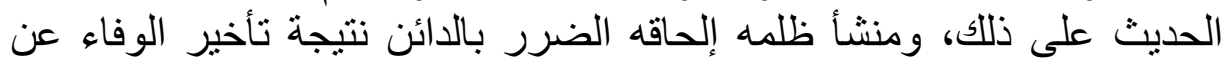

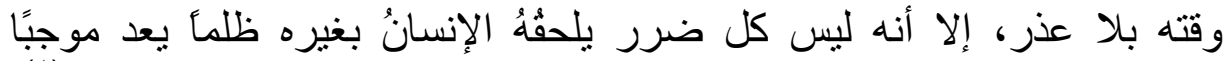
المالي (๕)

للتعويض وقله بلان

\section{ثانياً: أدلتهم من السنة.}

قول النبي وجه الدلائة: أفاد هذان الحديثان بأن مطل الغني ولي الواجد ظلم، و الظلم يحل

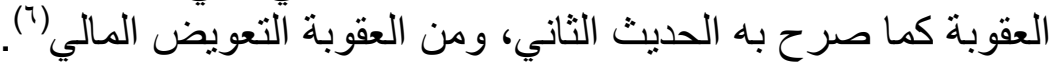

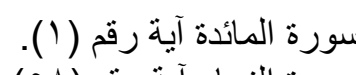

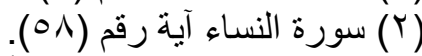

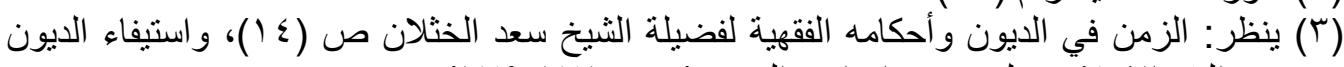

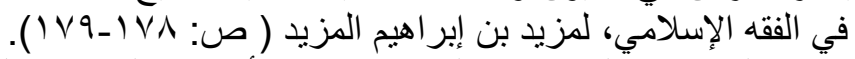

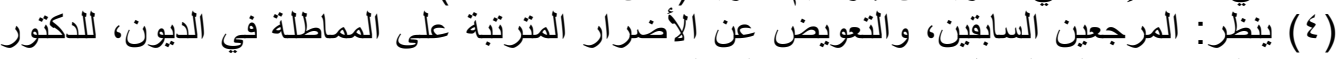
سلمان بن صالح الدخيل بحث منشور النعافين على النت. (0) (0) سبق تخريجهما. (7) ينظر : الزمن في الديون و أحكامه الفقهية لفضيلة الثيخ سعد الخثلان ص (ع () )، و الحلول و البدائل

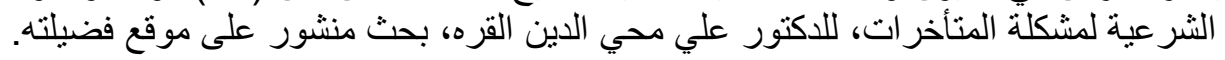




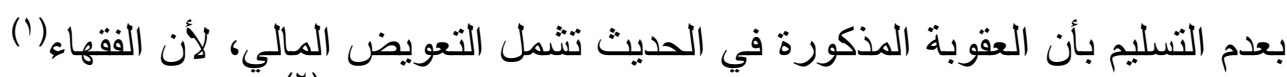

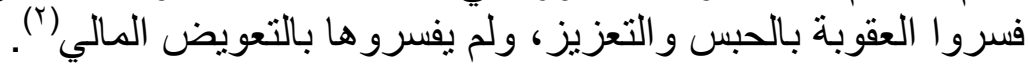

ثالثًا: أدلتهم العقلية.

1. قياس المدين المماطل على الغاصب؛ فكما أن الغاصب يضمن عين المال

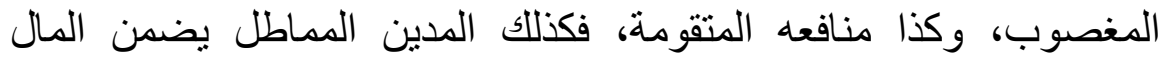

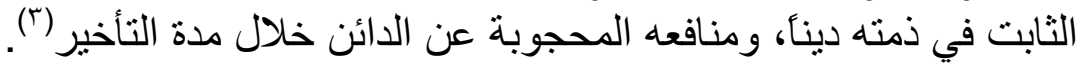

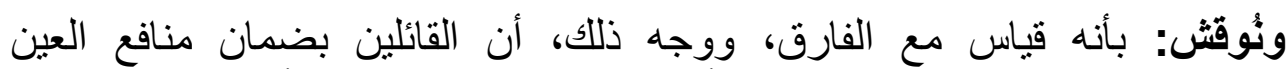

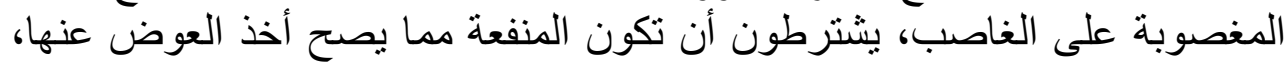

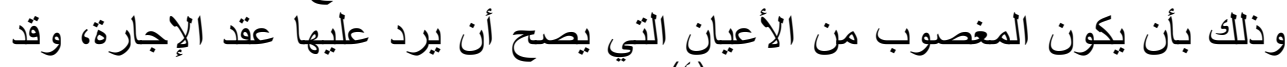

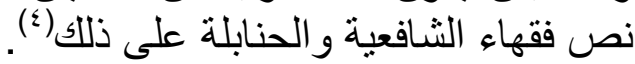

r. أن من مقاصد الثريعة الإسلامية وأسسها في تقرير الأحكام عدم المساواة

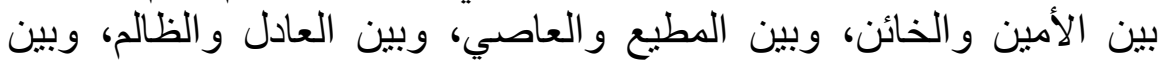

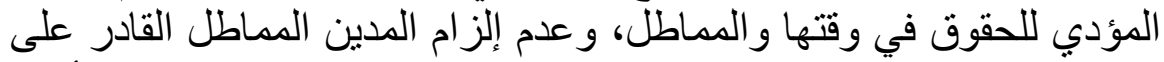

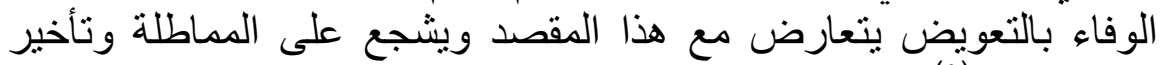
وفاء الحقوق(ن).

وئوقش: بعدم التسليم بأن عدم إلزام الدين المماطل بالتعويض يتعارض مع ما هو

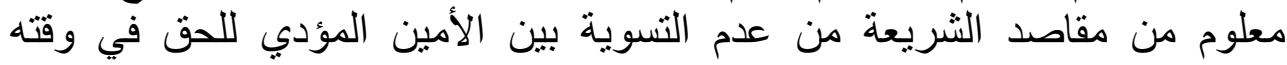
و المماطل الظالم، وبيان ذلك من وجهين:

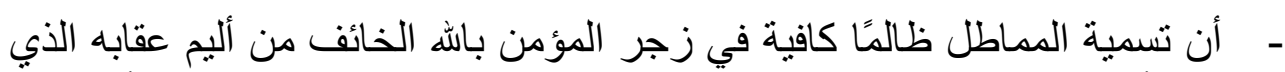

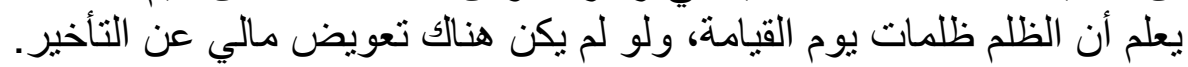
- وتردع غيره من المطل، وأخذ حقوق الناس، إما بالحبس، أو بما ير اه الحاكم من الحن

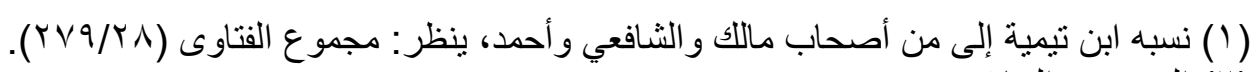

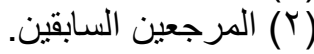

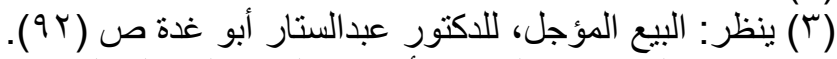

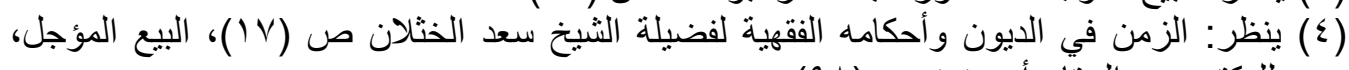

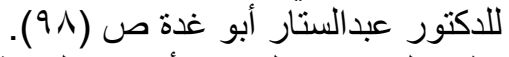

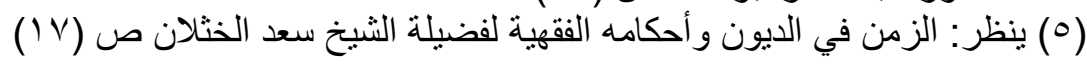




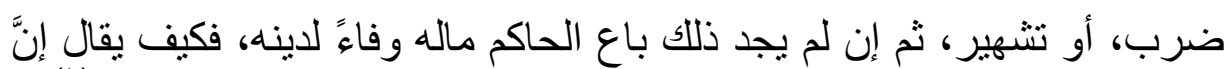

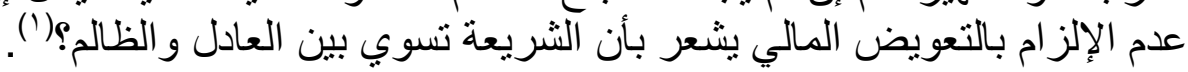

الذي يظهر - و العلم عند الله - رجحان القول الأول، القائل بعدم جواز إلزام المدين

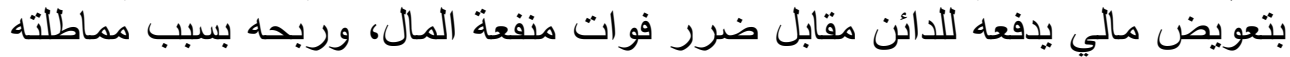

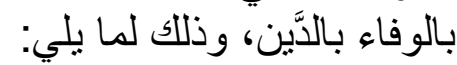

ا ـ قوة أدلة القائلين بالمنع، وضعف أدلة المجوزين، ومناقشة أدلتهح.

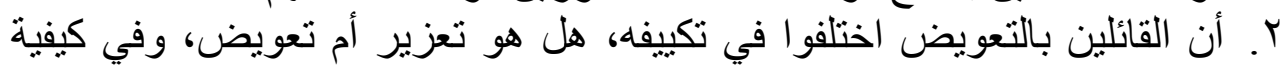

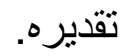
r. أن النتيجة النهائية للتعويض هي نفس نتيجة الربا، والفرق بينهما في التخريجات

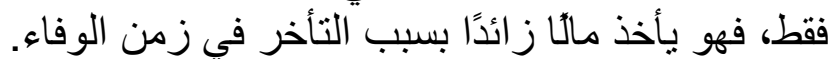

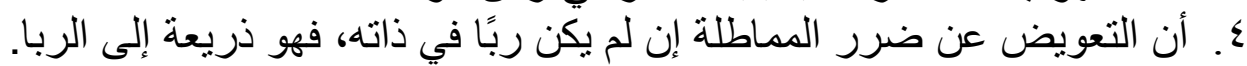
وقد عمل استبيان ضمن سبعة و عشرين مصرفًا إسلاميًا وكانت النتيجة على النحو الآتي:

- عدد المصارف التي تطبق غرامات التأخير اثنا عشر مصرقا وكلها تطبقها على

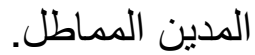
- غر امات التأخير بقرار من هيئة الرقابة الثرعية تسعة مصارف غير أن التطبيق العملي لا يو افق القرار في ثناثثة منها.

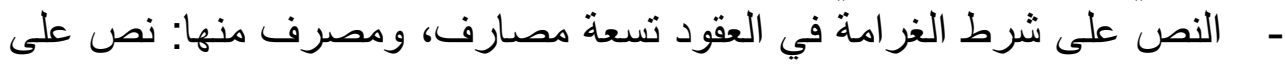

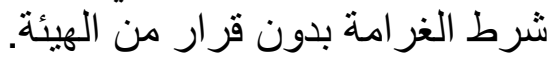

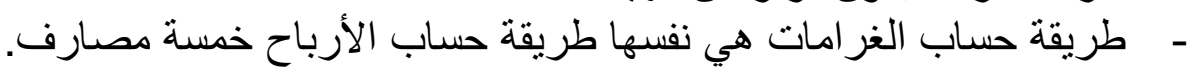
- الإير ادات تضاف لإير ادات المصرف أربعة مصارف.

و هذا الاستبيان يبين مدى التجاوزات الكبيرة من المصارف التهات التي ينكرها المجوزين

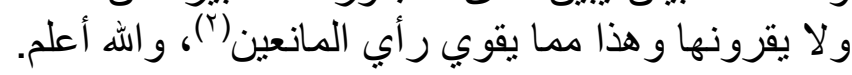




\section{المطالب الثانيي}

\section{الالتزام بزيادة بتصدق بـها عنـد تنأفر سداد الديز}

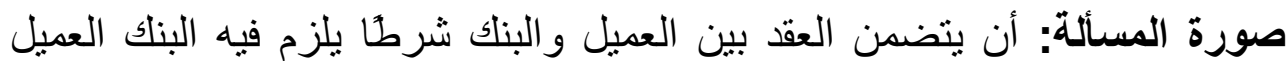

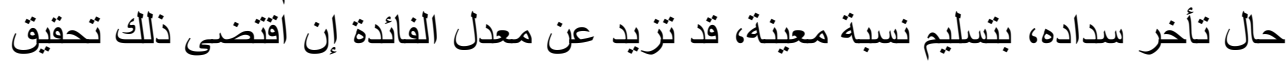

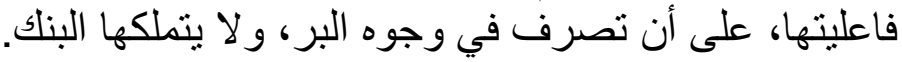

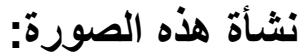

لم تكن هذه الصورة موجودة قديمًا، وإنما استجدت حديثّا، وكان سبب استحداثها

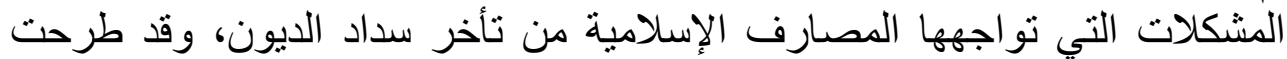

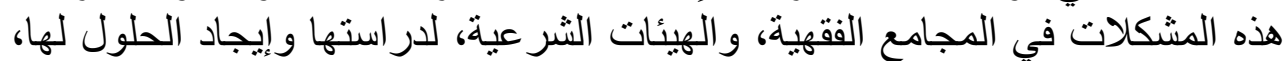

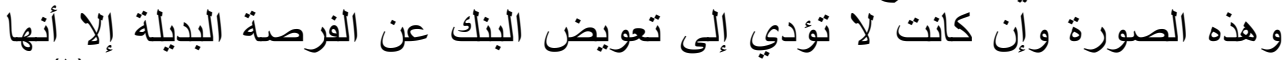
وسيلة للضغط على المدين المماطل؛ لأنه سيتفادى زيادة ما يستحن البن حال التأخير (').

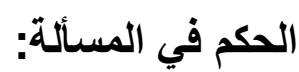

اختلف العلماء المعاصرون في المسألة على قولين:

القول الأول: عدم جواز هذه الزيادة، وهو قول المانعين للزيادة عند المماطلة مطلقًا،

وباه أخذ المجمع الفقهي الإسلامي (r).

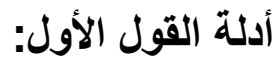

يستدل لهم بما سبق من تحريم الزيادة الناشئة عن المماطلة، وقد تقدم اير ادها.

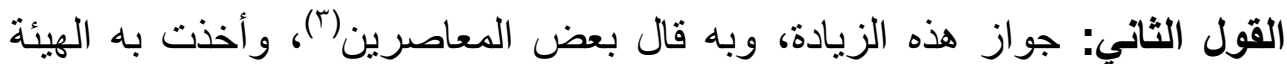

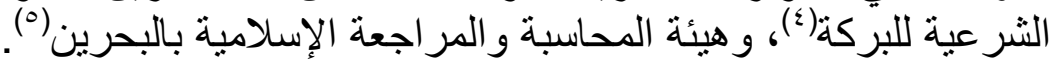

$$
\text { (1) ينظر : البيع المؤجل، للاكتور عبدالستار أبو غدة ص (90). }
$$

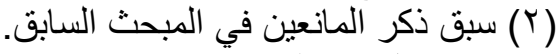

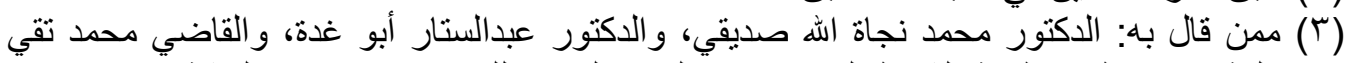

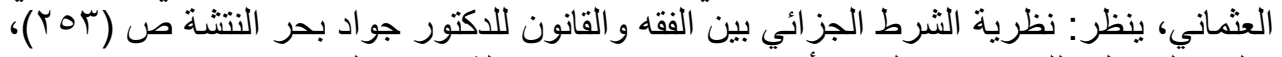

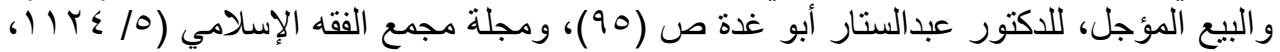

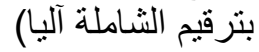

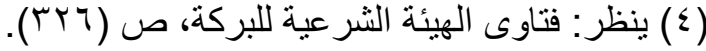

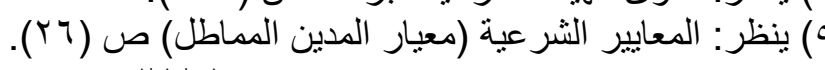




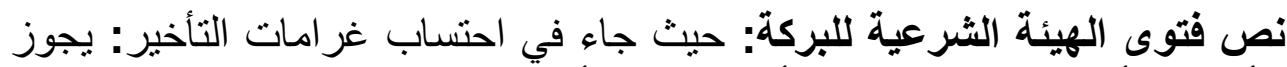

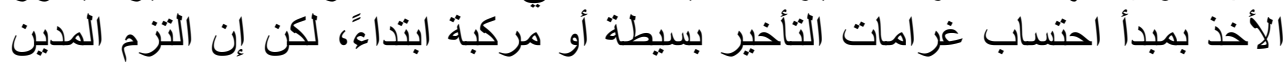

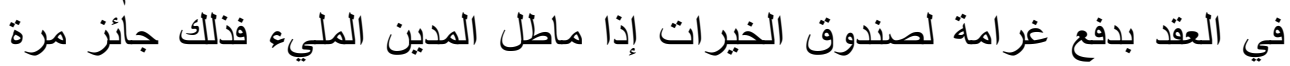

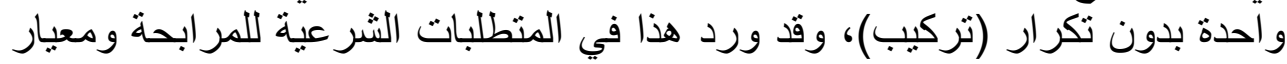

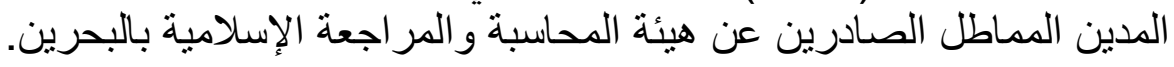

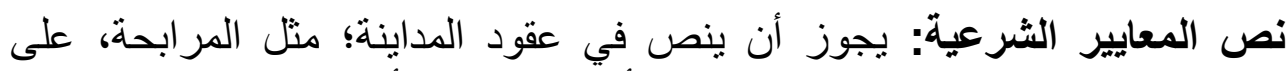

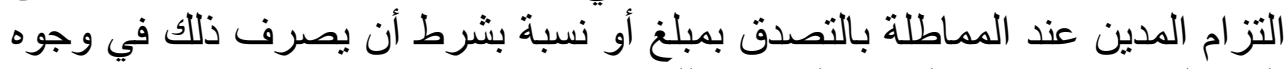

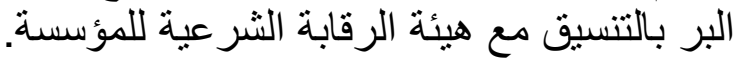

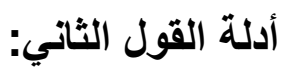

لم يُسعف أصحاب هذا القول أن يستدلو ا بما ذهبوا إليه، إلا بأدلة عقلية، ونقلٍ عن إئل أبي عبداله بن نافع، ومحمد بن إبر اهيم بن دينار من فقهاء المالكية.

أولَا: أدلتهم العقلية.

$$
\text { عبارة عن تعليلات وهي: - مئ }
$$

أ- إنه شرط تضمن مقصودًا صحيحًا وهو النفع للفقر اء (').

\section{ويمكن أن يُناقش بعدة أوجه:}

1. عدم التسليم، فليس كل ما تضمن نفعًا للغير فهو مشروع؛ فالسرقة حرام

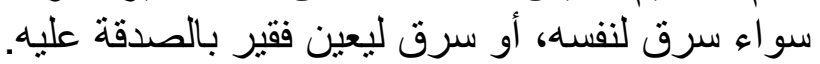

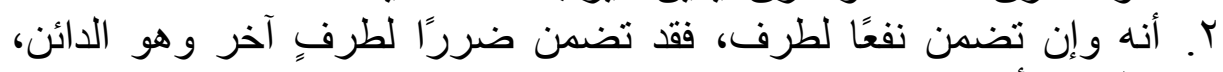

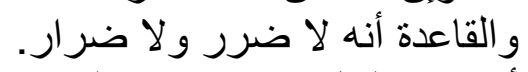

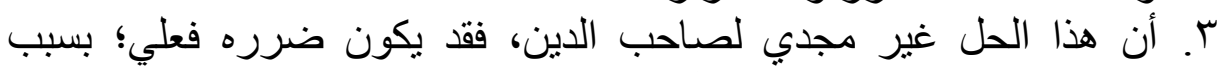

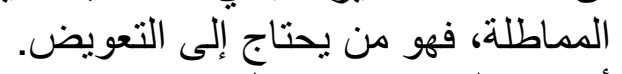

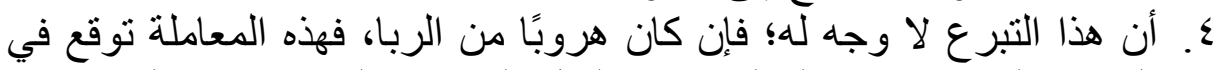

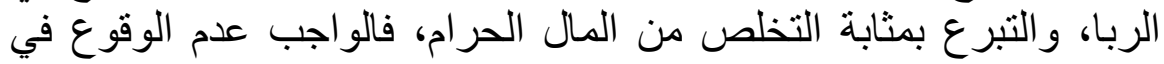
المحرم، وليس تسويغ الوقوع فيه، بذريعة التخلص من المال الناتج عنه.

$$
\text { بـ أن فيه حفز للمدين على الوفاء بالدين في الوقت المحدد(؟). }
$$


ويمكن أن يُناقش: بأنه إن كان فيه حفز على الأداء إلا أن الوسيلة محرمة.

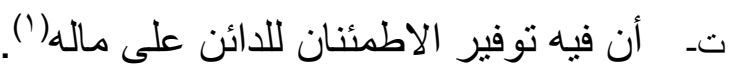

ويمكن أن يُناقش: بأن الثرع جعل وسائل للاطئنان كالرهن، و الكفالة، ولو كانت هذه وسيلة مشرو عة لبينها.

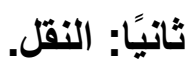

فقد قال الحطاب:" و أما إذا التزم الددعي عليه للددعي أنه إن لم يوفه حقه في وقت كذا لألها

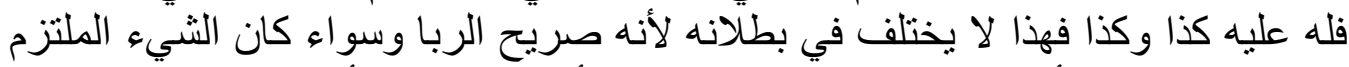

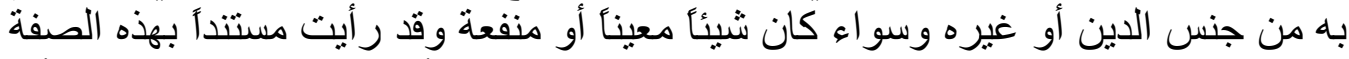

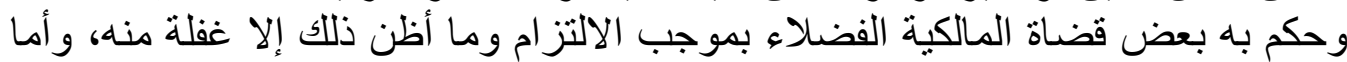

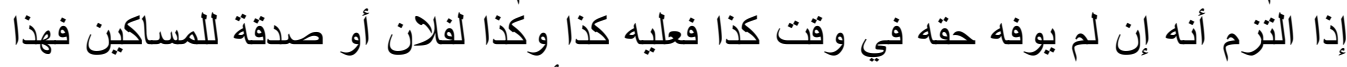

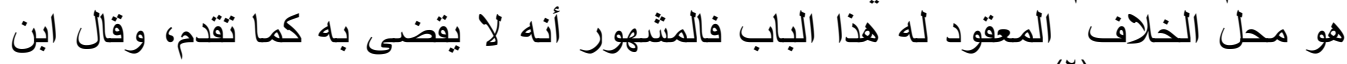

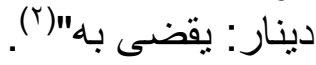

ويمكن أن يُناقش: بما نص عليه الحطاب أن المشهور عدم صحته قضاءً، فالقول

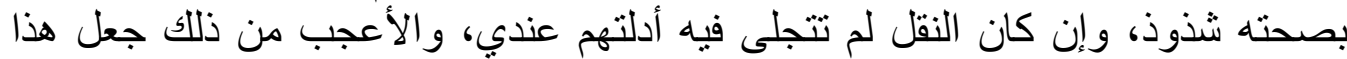

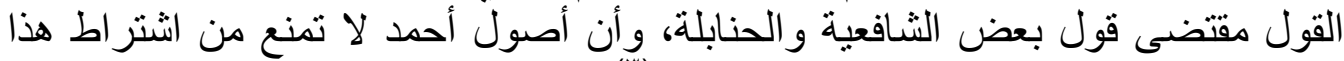

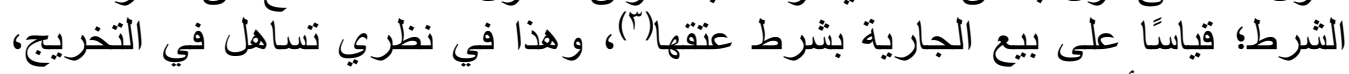

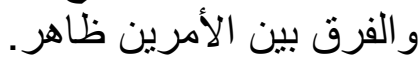

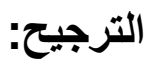

الذي يظهر - والعلم عند اله - رجحان القول الأول القائل بعدم جواز الزيادة لأجل

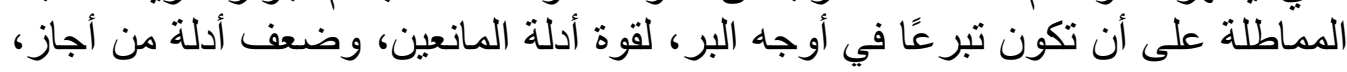

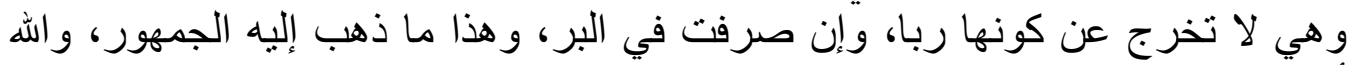




\section{المبمث الثالث}

\section{المالمة عن الدين المؤجل ببعضه حالاً}

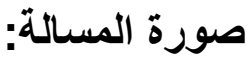

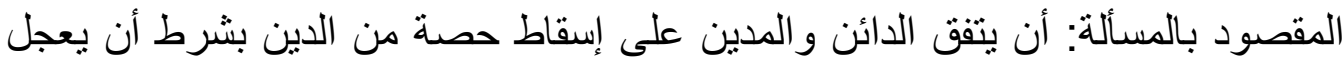

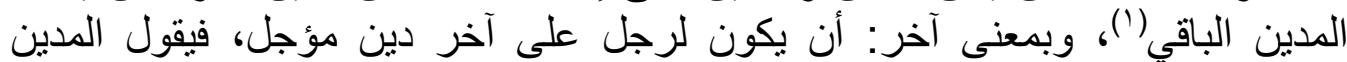

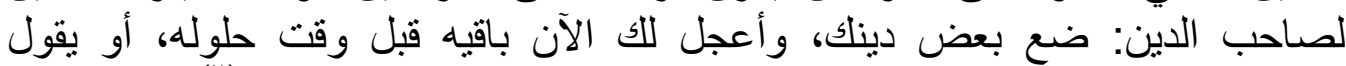

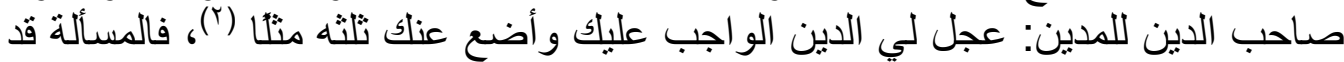
يطلب العمل بها الدائن أو المدين.

الأقوال في المسألة: اختلف العلماء في حكم الحط من الدين المؤجل مقابل تعجيله على قولين:

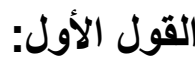

تحريم الحط من الدين المؤجل مقابل تعجيله، وهو قول جمهور العلماء من الحنفية(r)،

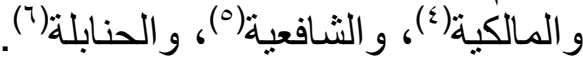

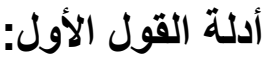

أولاً: من السنة.

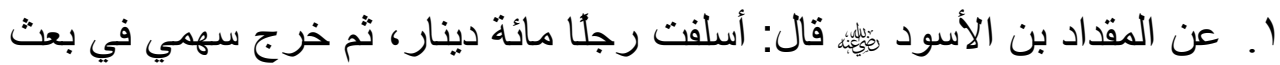

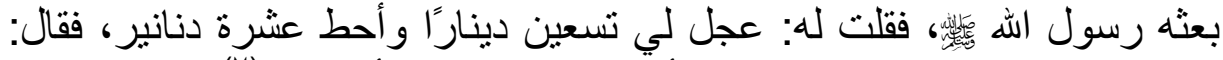

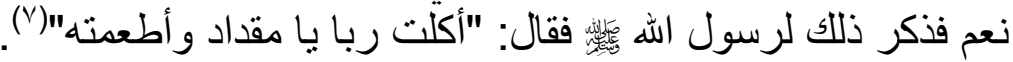

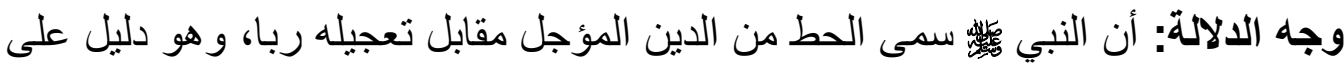
تحريمه، و المنع منه.

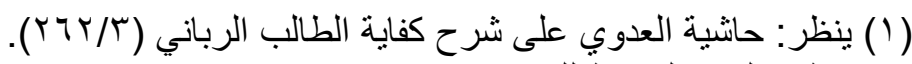

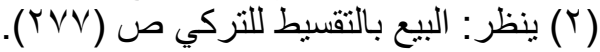

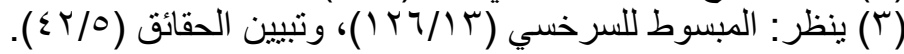

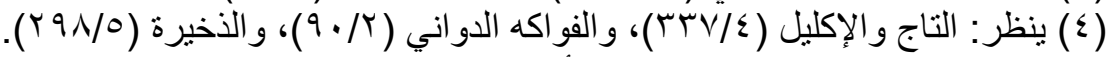

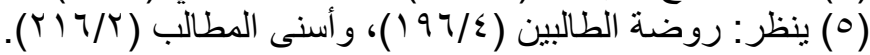

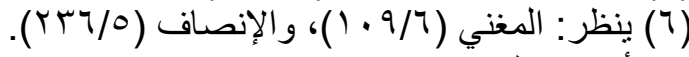


وقد نُوقش: بأنه وإن كان صريحًا في دلالته إلا أنه ضعيف من جهة السند فلا يحتج

r. وورد النهي عن الحط من الدين المؤجل مقابل تعجيله عن بعض الصحابة

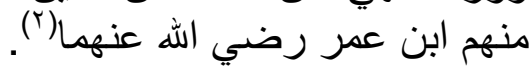

وثُوقش: بأنه اجتهاد صحابي، وقد خالفه فيه غيره، وقول الصحابي لا يكون حجة إذا

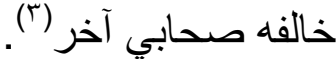

ثانياً: أدلتهم العقلية.

القياس: فقالوا: إن الحط من الدين المؤجل مقابل تعجيله مثل الزيادة فيه مقابل تأجيله

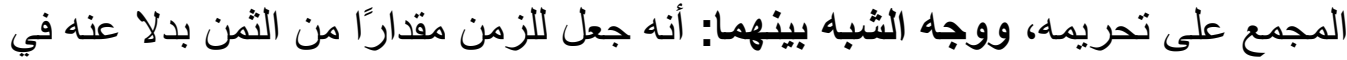

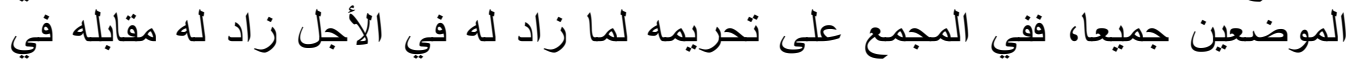

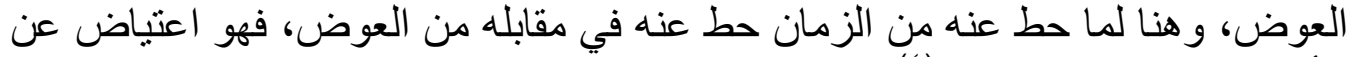

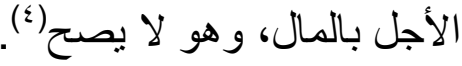

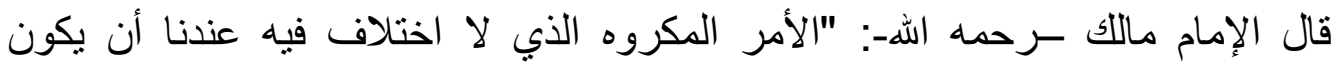

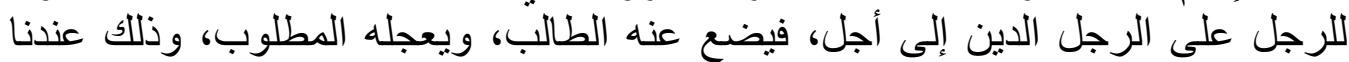
بمنزلة الذي يؤخر دينه بعد محله عن غريمها، ويزيده الغريم في في حقه فهذا الربا بعينه لا لا شك فيه"(0)"

و هذا الدليل هو عمدة المانعين من هذه المسألة، وهو قائح على قياس (ضع وتعجل) على الألى (زد وتأجل)، بجامع الاعتياض عن عن الأجل في كل منهماء")

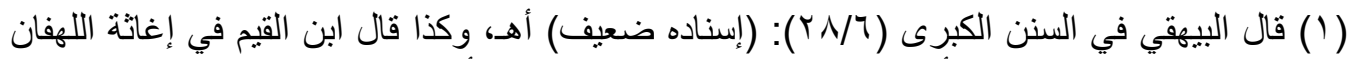

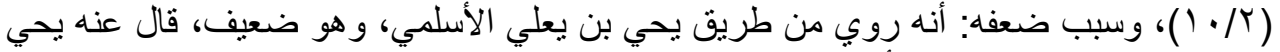

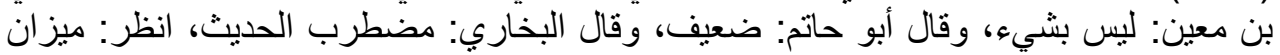

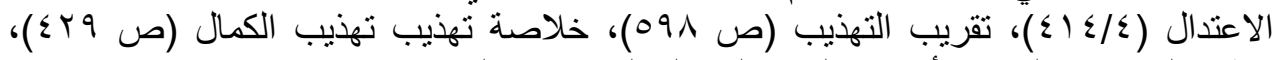

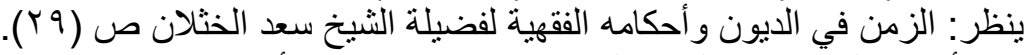

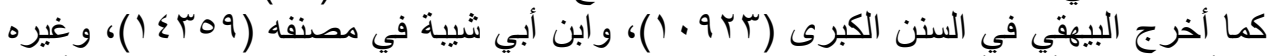

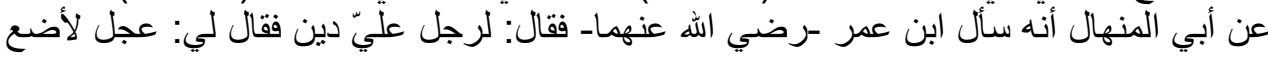

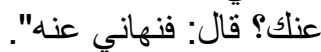

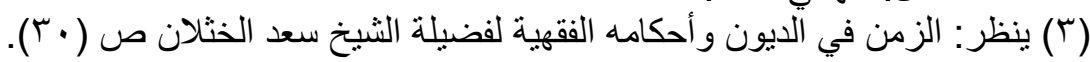

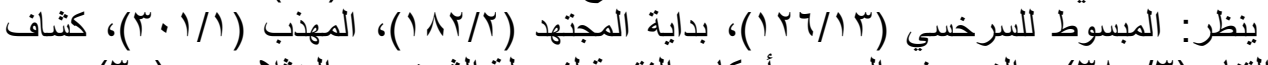

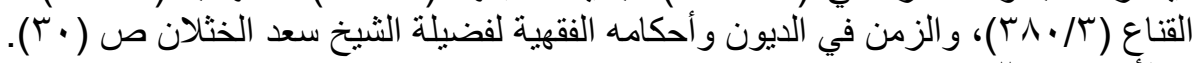

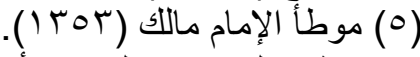

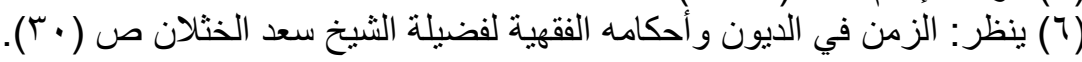




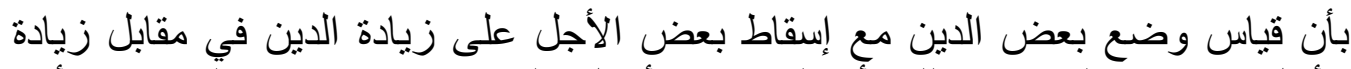

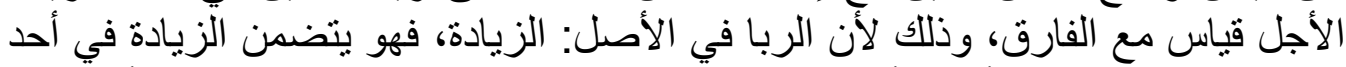

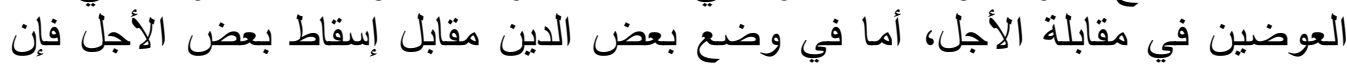

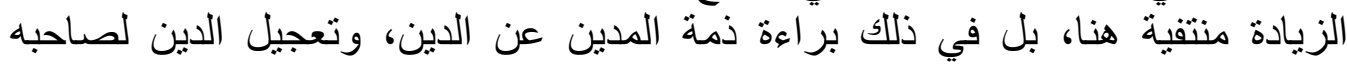

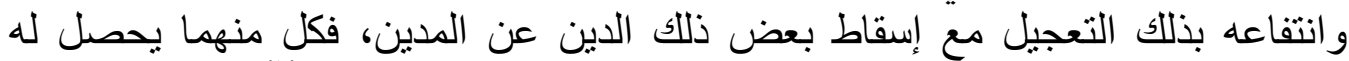

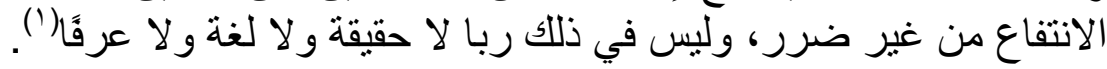

القول الثاني: جواز الحط من الدين المؤجل مقابل تعجيله، وهو مروي عن بن عباس الإس

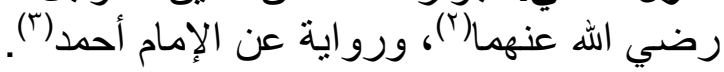

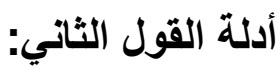
أولاً: من السنة. عمدة ما استدل به أصحاب هذا القول ما جاء عن ابن عباس -رضي الله عنهما- قال: لما أر اد رسول الله

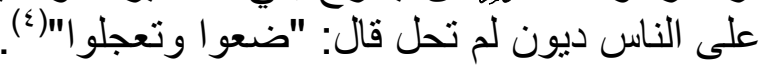

ويُوقُش: بأنه ضعيف من جهة السند؛ فمداره على مسلم بن خالد الزنجي، وقد ضعفوه(ْ). وأجيب: بأنه و إن ضعفوه فهو موثق عند آخرين(؟). ثانياً: الأدلة العقلية.

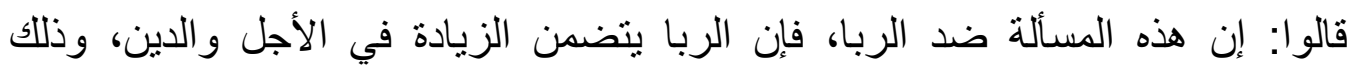

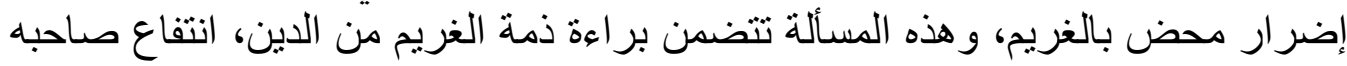

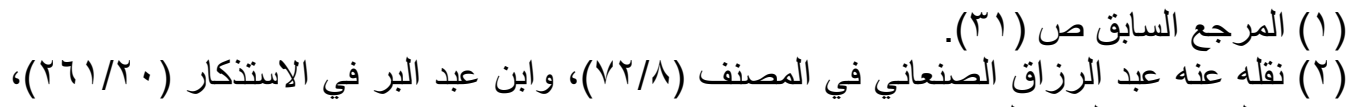

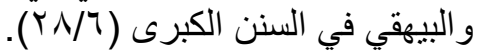

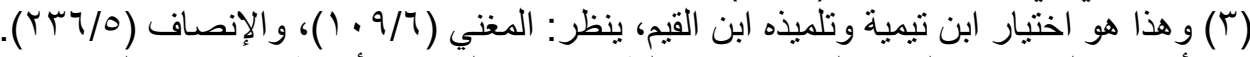

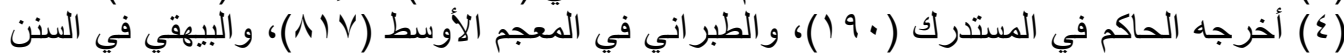

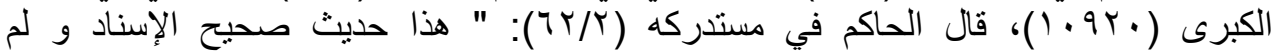

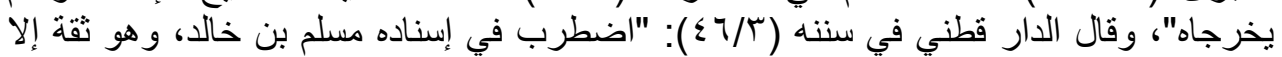

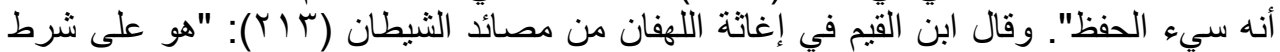

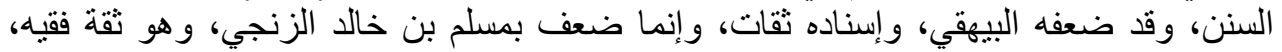

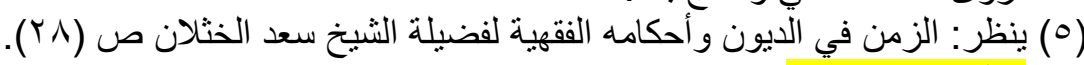




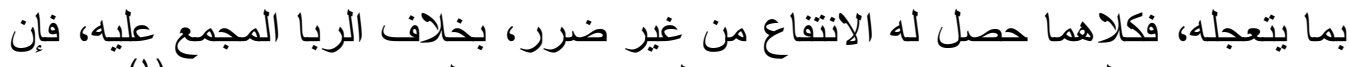

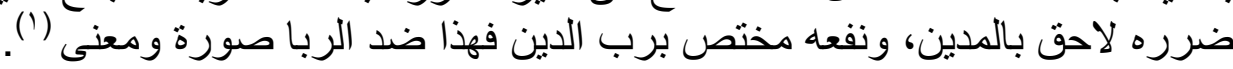

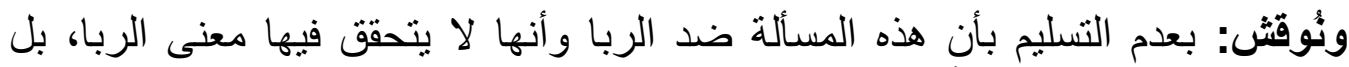

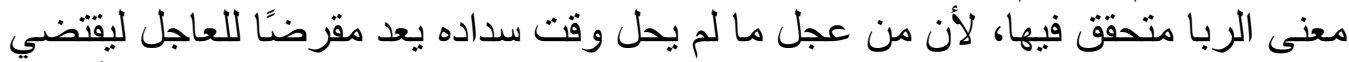

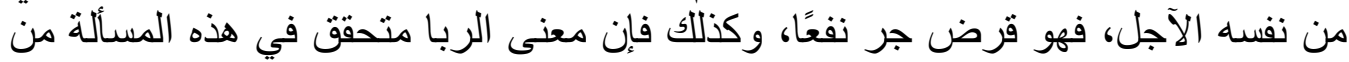

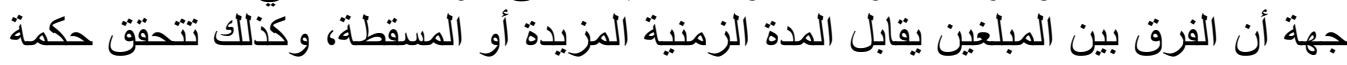
الربا فيه، حيث إن المرابي يستغل حاجة المدين، وهنا المدين يستغل المن حاجة أخيه

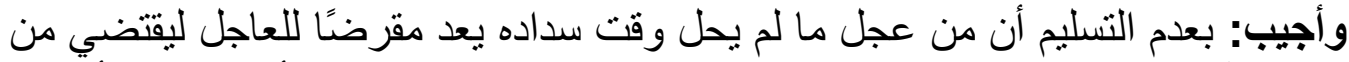

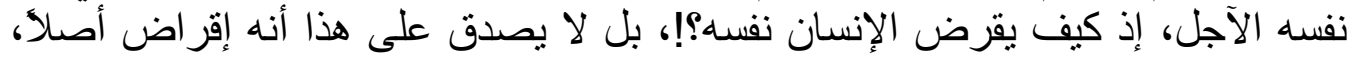

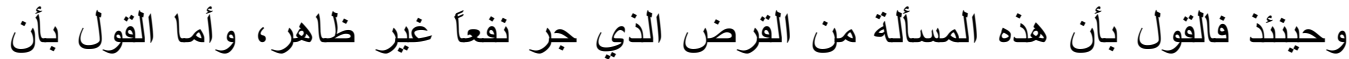

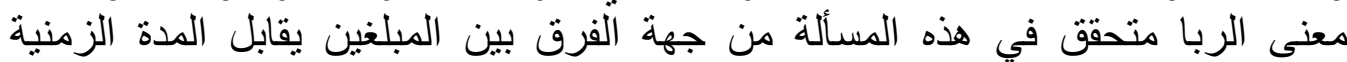

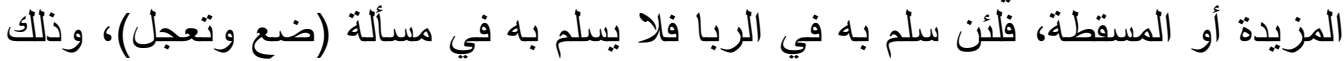

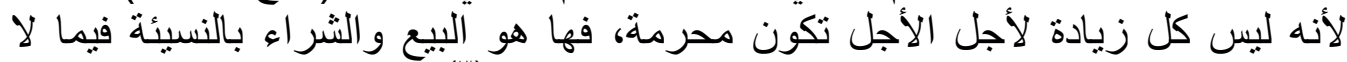

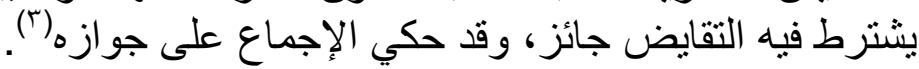

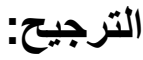

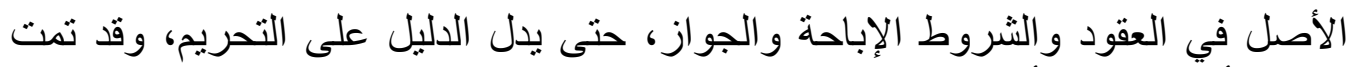

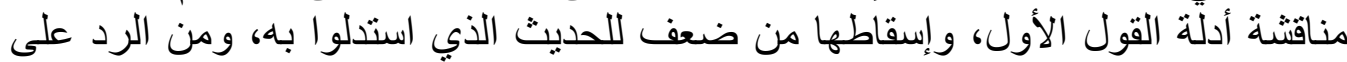

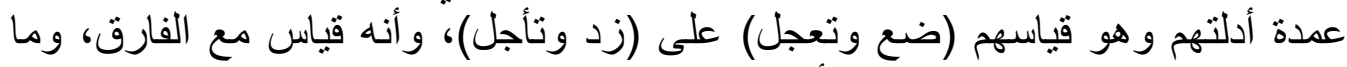

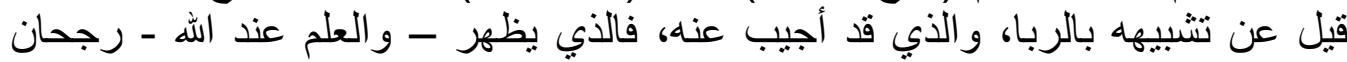

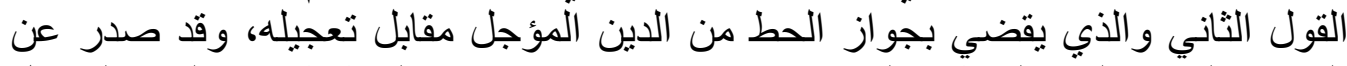

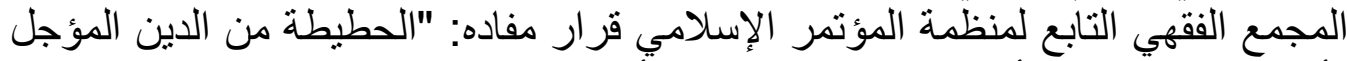

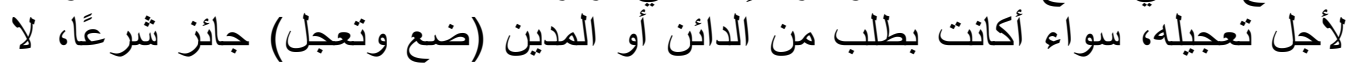

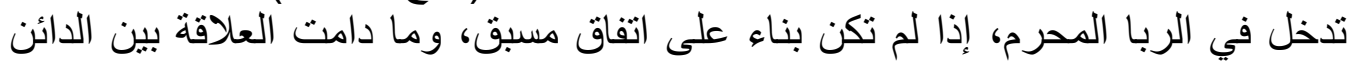

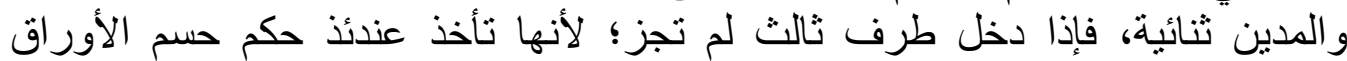

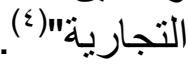

( ( الزمن في الديون وأحكامه الفقهية لفضيلة الثيخ سعد الخثلان ص (Y^).

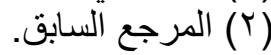

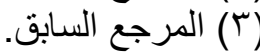

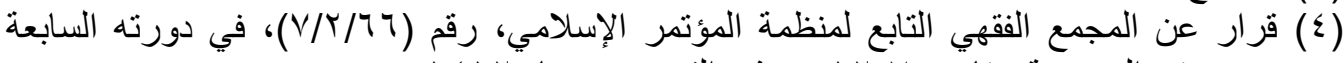

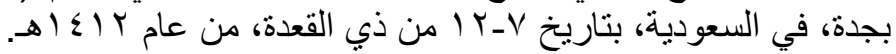




\title{
المبحث الرابع
}

\author{
تطبيقق قضائي

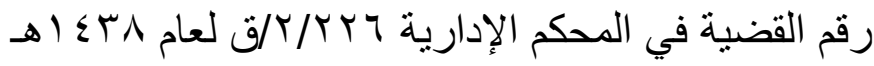

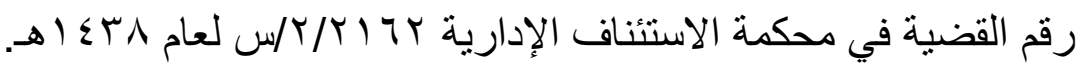

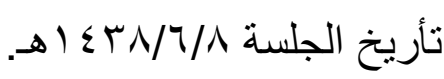

\section{الوقائم:}

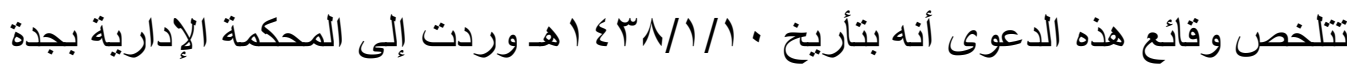

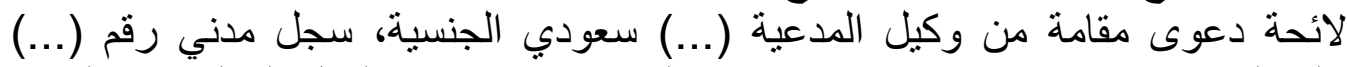

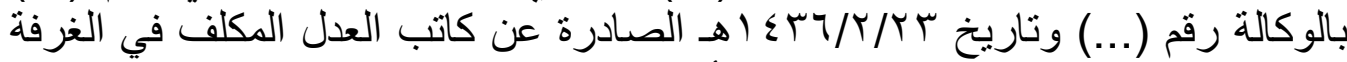

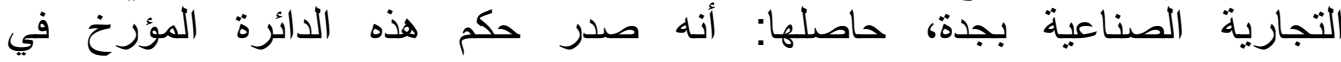

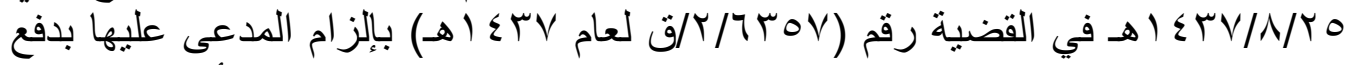

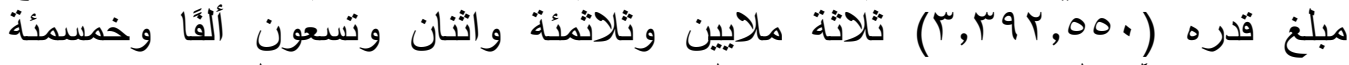

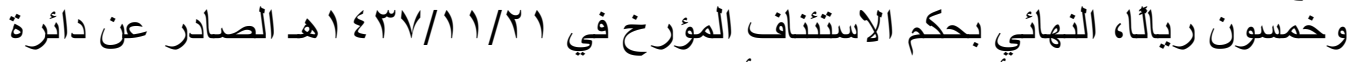

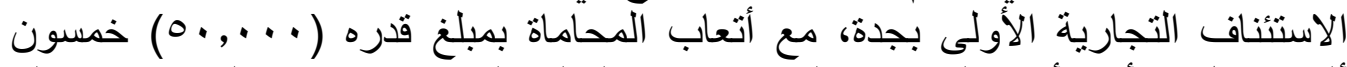

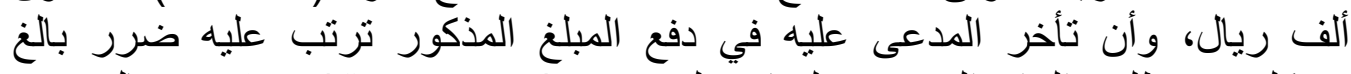

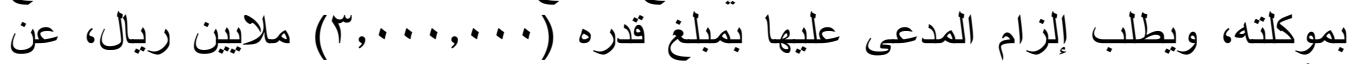

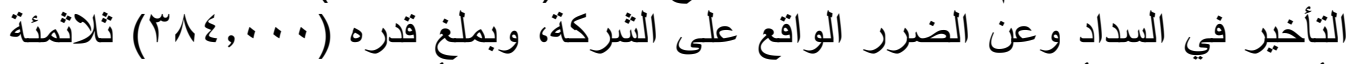

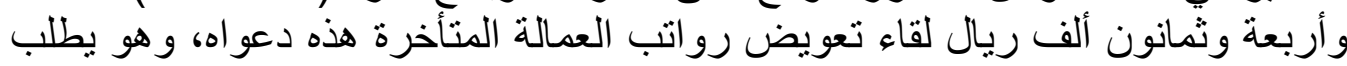

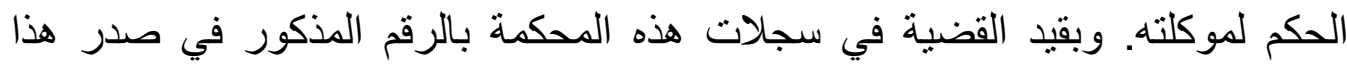
الحكم وبإحالتها لهذه الدائرة باثرت النشي النظر فيها في عدة جلسات.

\section{1}

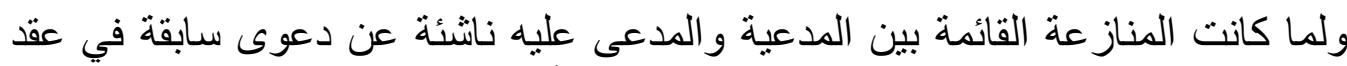

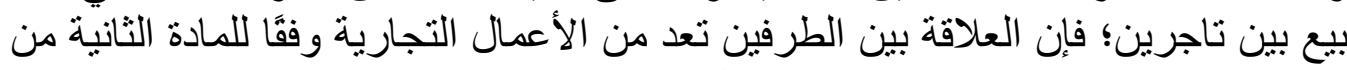

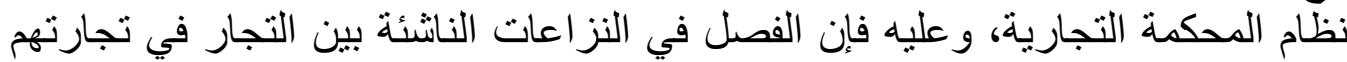

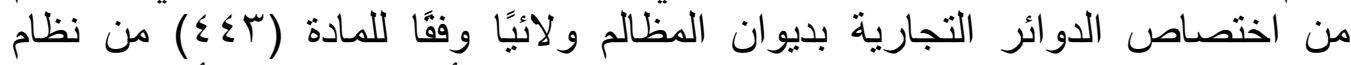

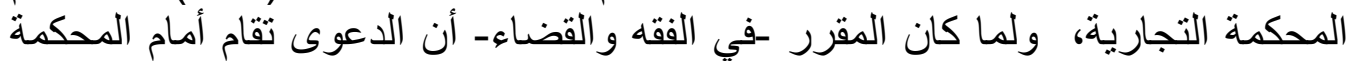

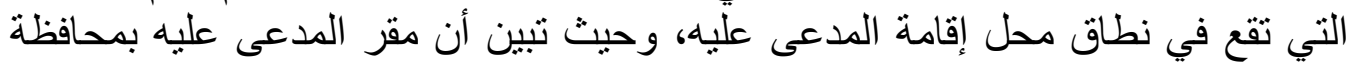

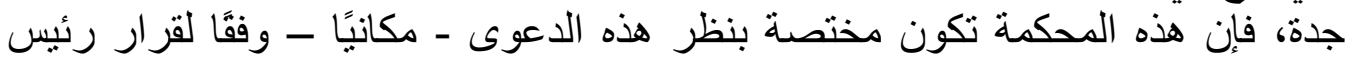

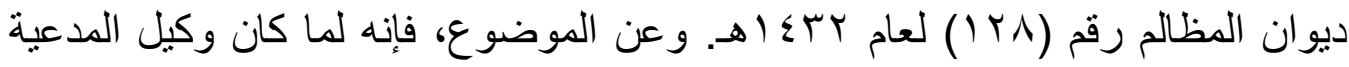




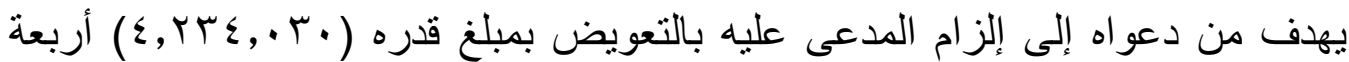

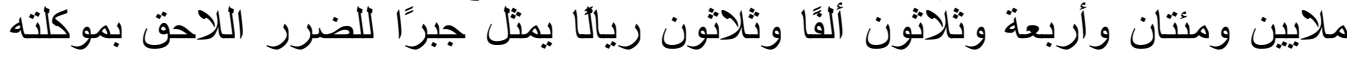

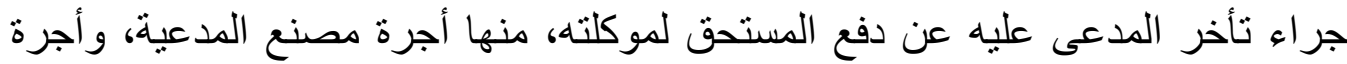

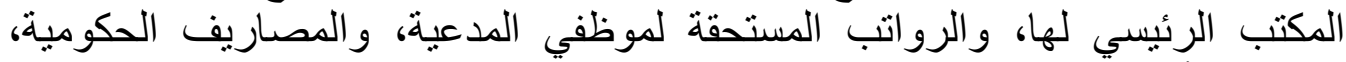

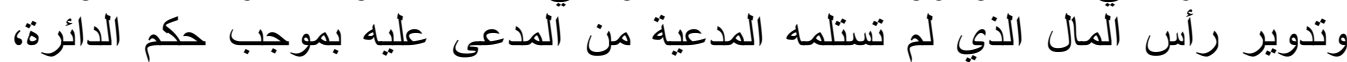

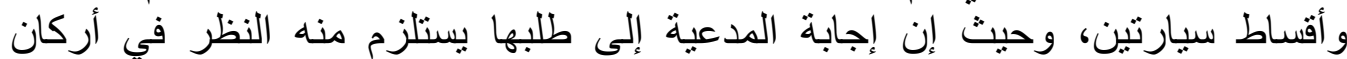

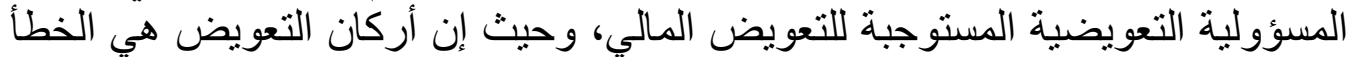

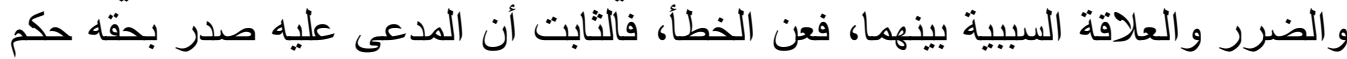

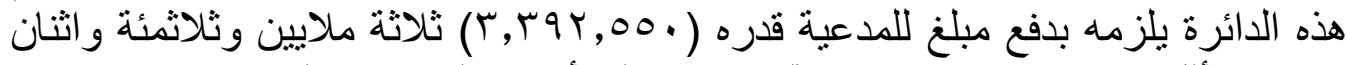

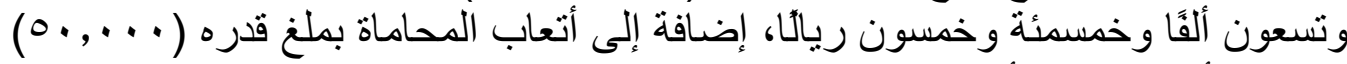

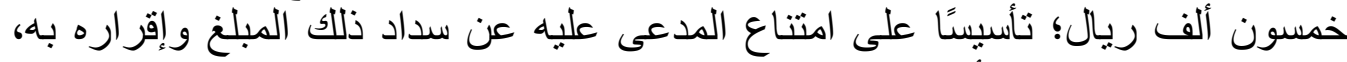

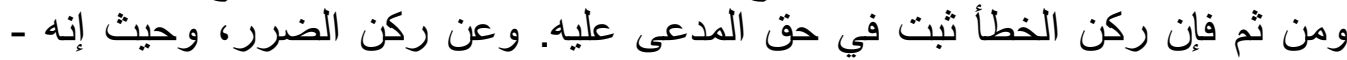

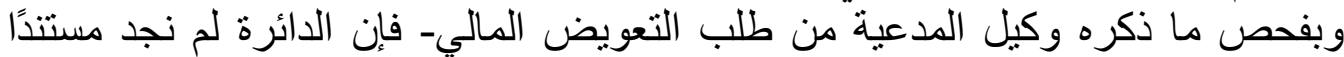

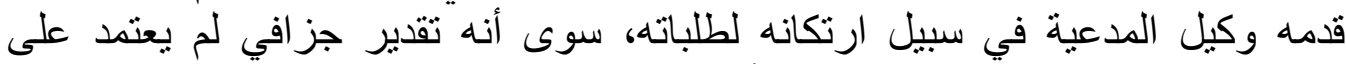

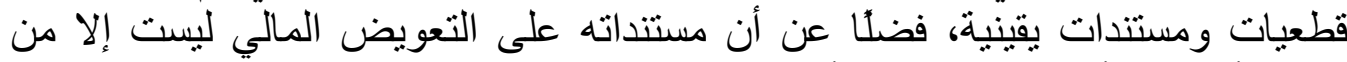

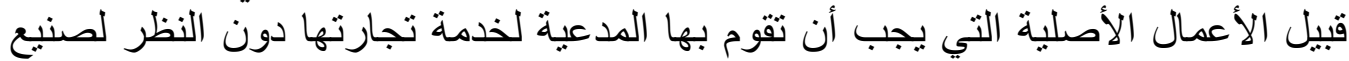

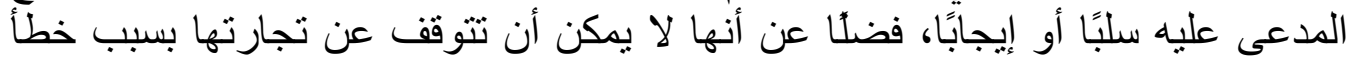

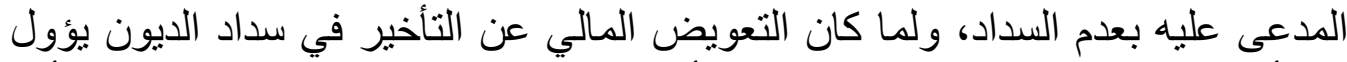

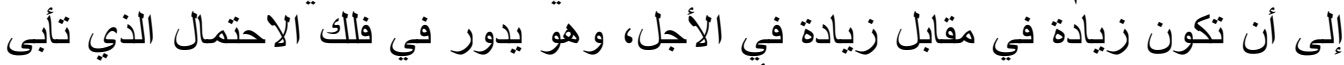

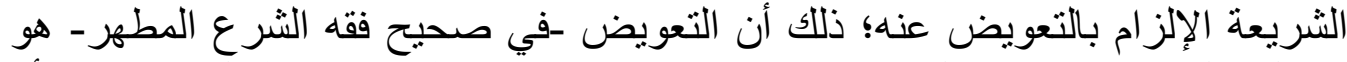

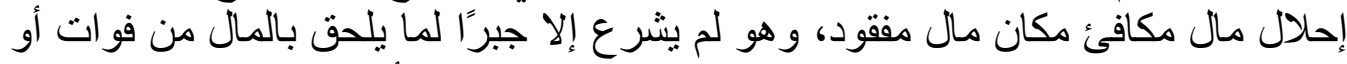

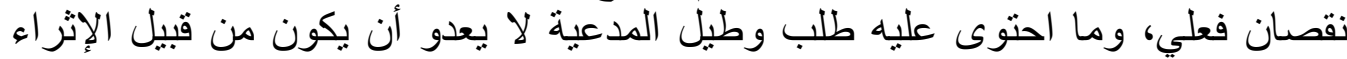

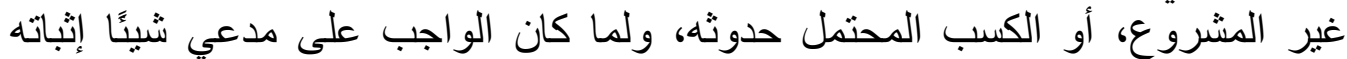

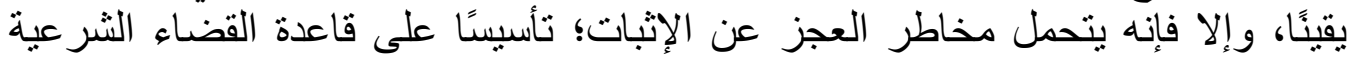

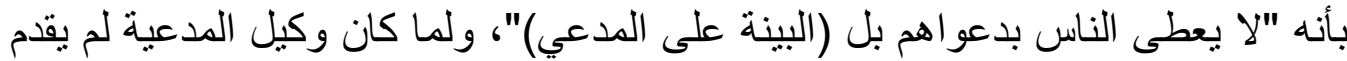

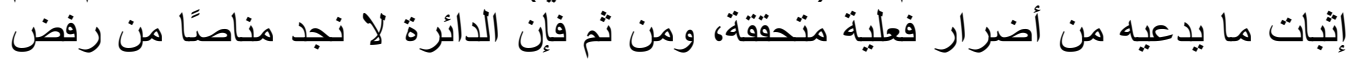
طلب المدعية التعويض، وبهذ أنرا تقضي.

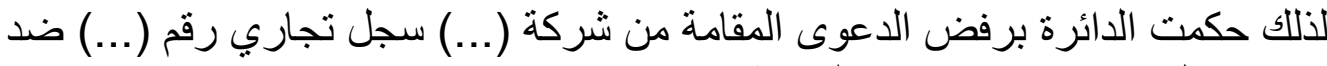

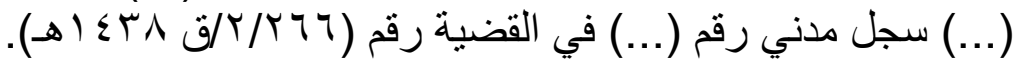

و الله الموفق، وصلى الله وسلم على نبينا محمد و على آله وصحبه أجمعين. 


\section{التعلية:}

من خلال وقائع القضية المذكورة، نجد أن المدعية تطالب بزيادة على الدين المستحق في

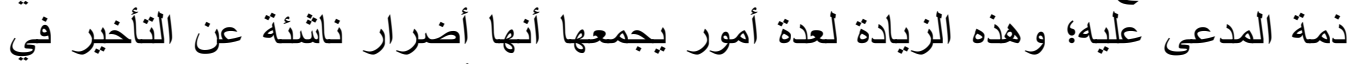

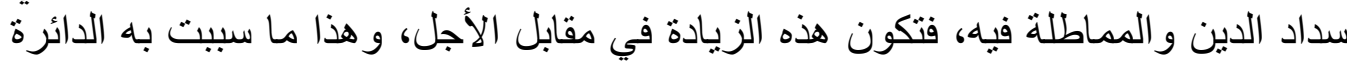

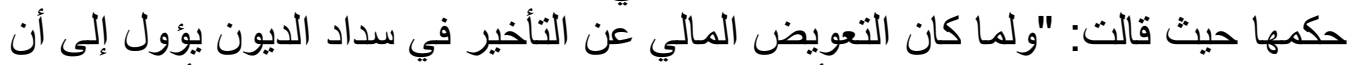

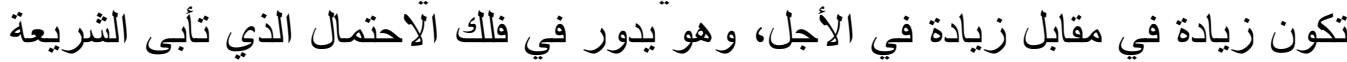

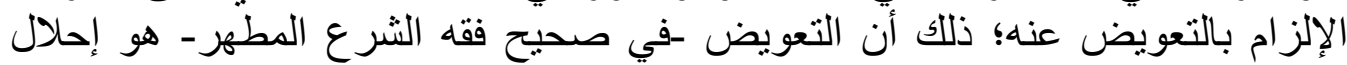

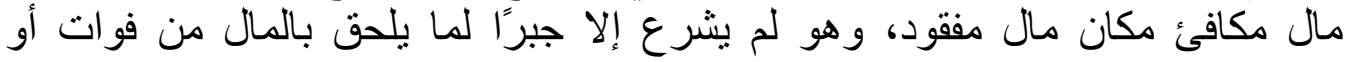

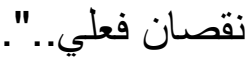

و هذا يؤيد ما سبق في البحث وهو أن الزيادة في الدين لا تجوز شرعًا حتى ولو كانت

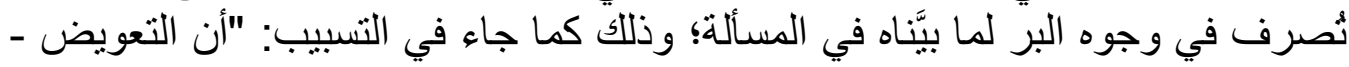

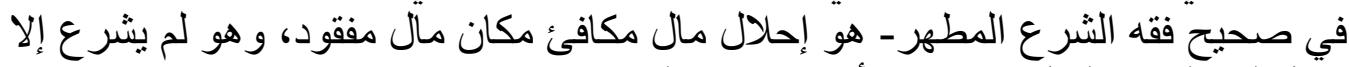
جبرًا لما يلحق بالمال من فو ات أو نقصان فعلي". 


\section{خاتمة}

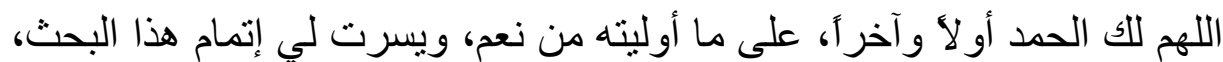
إلى أن بلغت هذه الخاتمة التي سأبين فيها أبرز ما توصلت إليه من من نتائج، أوجز ها فيما

1. اللققهاء في تعريف الدين قولين:

الأول: المال الثابت في الذمة بدلا عن شيء آخر، وهذا ما ذهب إليه جمهور الحنفية

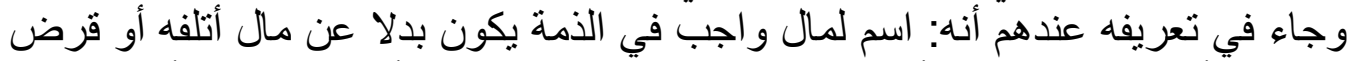

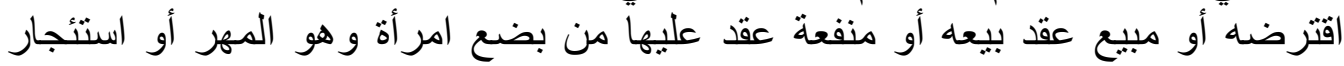
عين.

الثاني: المال الثابت في الذمة، وهو قول الجمهور، فكل ثابت في الذمة سواء كان بدان النا

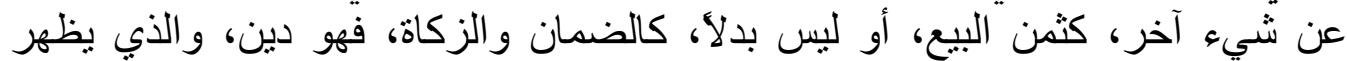

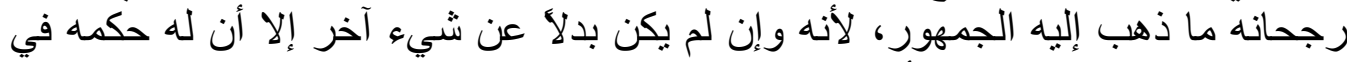

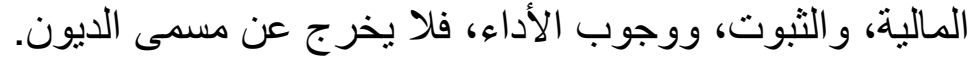

r. الزيادة المرتبطة بالزمن في الدين أجمع الفقهاء على تحريمها، وهي إحدى صور ربا الجاهلية التي ورد النص بتحريمها.

r. القول بجواز زيادة الثمن المؤجل في البيوع عن الثمن الحال، هو قول جماهير

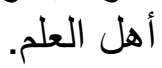
؛. . المدين إن كان غنياً قادر أ على الوفاء، فإنه يحرم عليه المماطلة.

○. الذي يظهر - والعلم عند الله - رجحان القول القائل بعدم جواز إلزام الددين

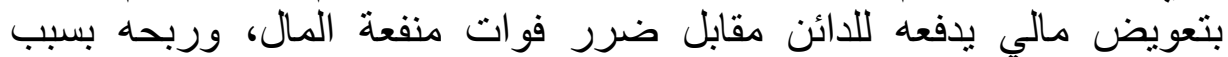

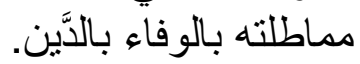

T. الذي يظهر - والعلم عند الله - رجحان القول القائل بعدم جواز الزيادة لأجل المماطلة على أن تكون تبر عا في أوجه البر.

V. الذي يظهر - و العلم عند الله - رجحان القول القائل بجواز الحط من الدين

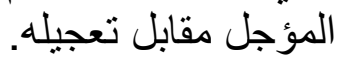

^. أن القضاء في المملكة العربية السعودية لا يأخذ بمسألة التعويض في المماطلة إلا ما كان جبرًا لما يلحق بالمال من فوات أو أل نقصان فعلي. 
9. أن التطبيقات القضائية ذات أهمية في مجال الفقه وهي جانب عملي للفقيه،

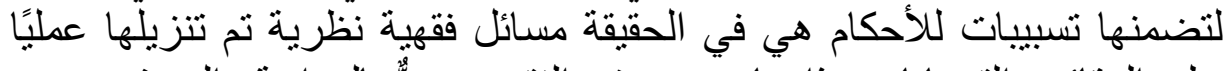

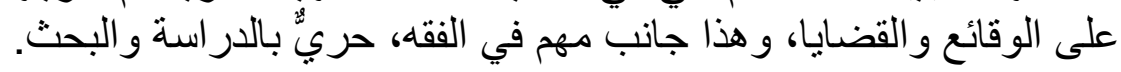
تللك هي أهم النتائج التي توصلتُ إليها من خلال هذا البحث، وهنالك فوائد أخرى في ثناياه.

و ها أنا ذا قد أتيت على مسك الختام، فاغفر اللهم زلات القدم، وما أخطأ، أو سهى به وأها

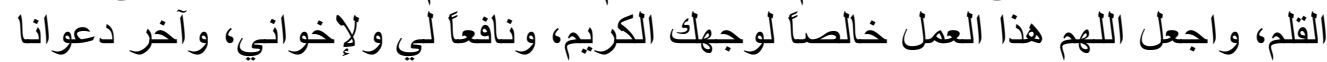

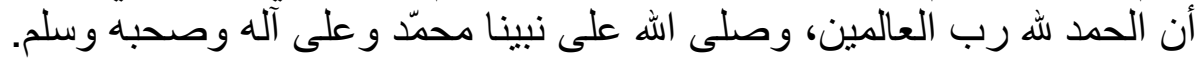




\section{الملاهمة}

\section{فتاوى اللجنة الدائمة:}

السؤال الثامن من الفتوى رقم r • ـ 1 إ:

س^^: ما الفرق بين بيع التقسيط ومسألة التورق؟

ج^: بيع التقسيط هو: بيع السلعة بثمن مؤجل، يسدده على فترات متفرقة، وأما مسألة

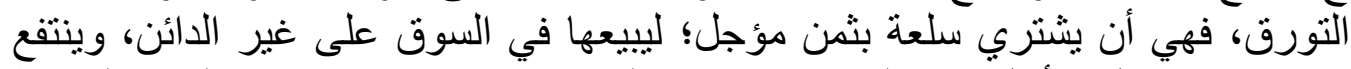

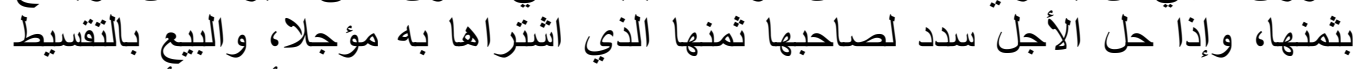

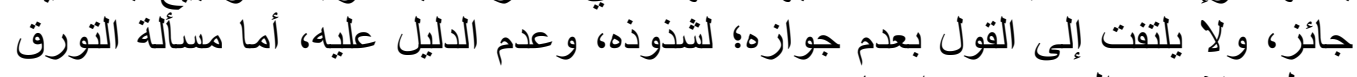
فمحل خلاف، و والصحيح جواز ها.

وبالهه التوفيق وصلى الله على نبينا محمد و آله وصحبه وسلم. اللجنة الدائمة للبحوث العلمية والإفتاء عضو ... عضو ... عضو ... عضو ... نائب الرئيس ... الرئيس بكر أبو زيد ... عبد العزيز آل الثيخ ... صالح الفوزان ... عبد الله بن غديان ... عبد بل باز

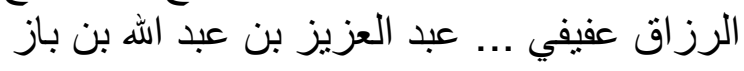

فتاوى اللجنة الدائمة: الفتوى رقم (IV (I ) :

س: شخص يعمل بتجارة السيارات، حيث يقوم بييع السيارات بطريقة التقسيط، فيبيع

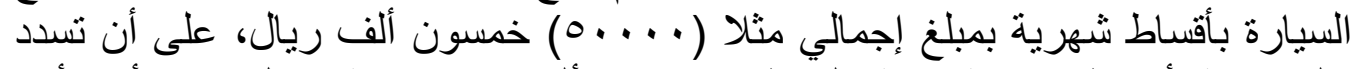

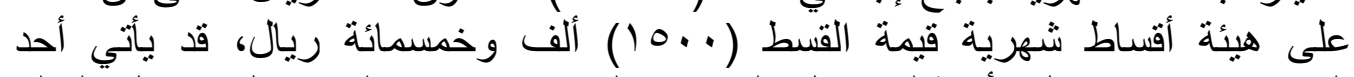

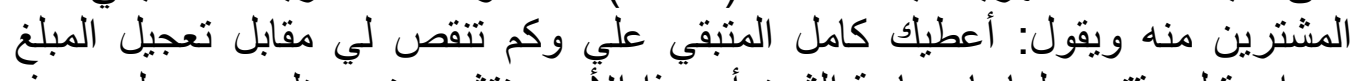

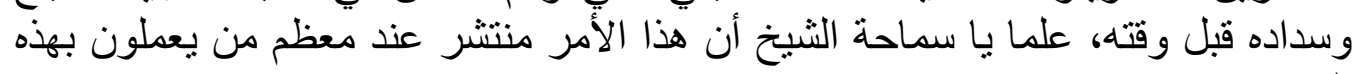

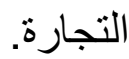

نأمل إفتاء المذكور حول استفتائه، وما الحكم إن قال لمشتري: أنا سأعطيك كامل

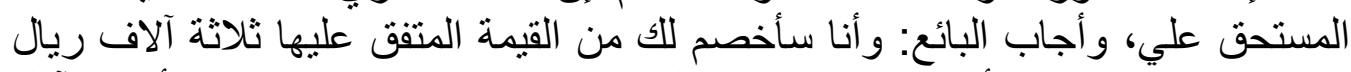

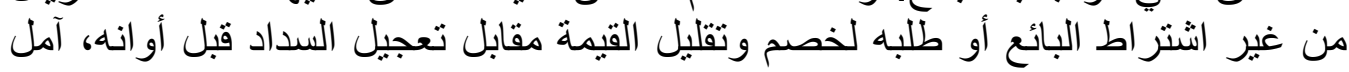
إفتاءنا حول ما سبق حفظكم الله وسدد على الخير خطاكم. والسلام عليكم ورحمة الله وبركاته. 
ج: ما ذكر في السؤال هو ما يعرف عند الفقهاء بمسألة: (ضع وتعجل) ، وفي جوازها

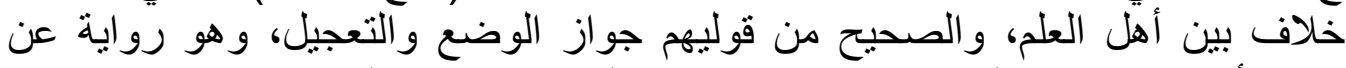

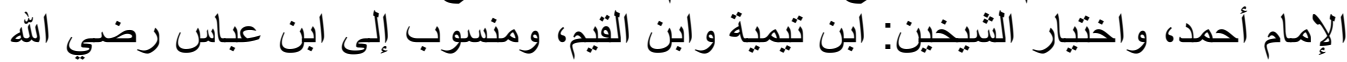
عنهما.

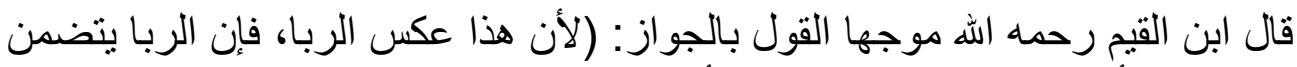

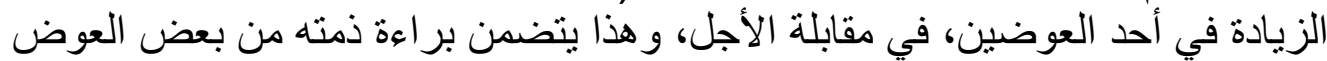

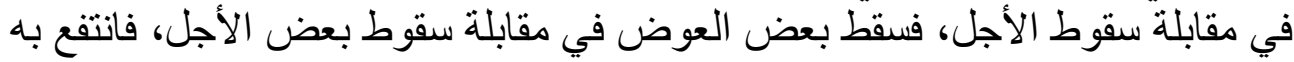

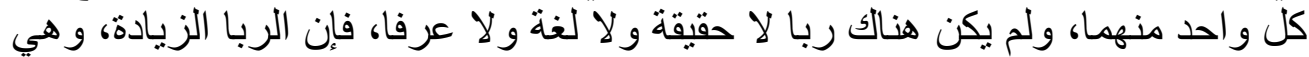

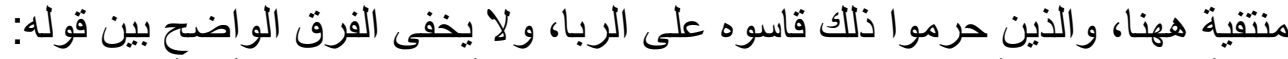

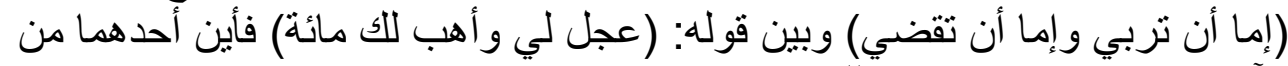

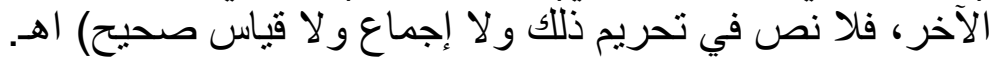
وبالله التوفيق وصلى الله على نبينا محمد و آله وصحبه وسلم. اللجنة الدائمة للبحوث العلمية والإفتاء عضو ... عضو ... الرئيس بكر أبو زيد ... عبد العزيز آل الثيخ ... عبد العزيز بن عبد الهه بن باز 


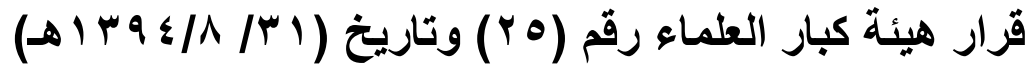

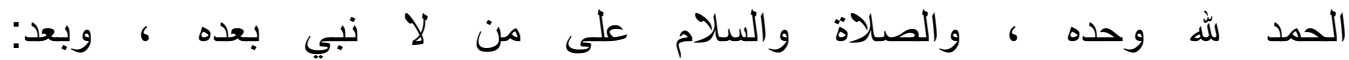

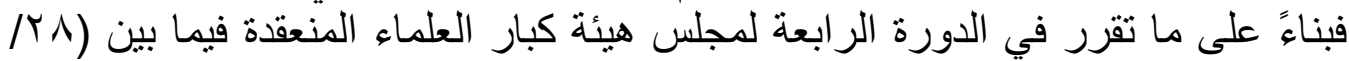

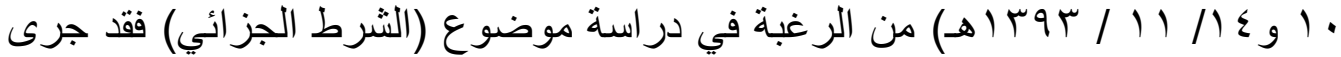

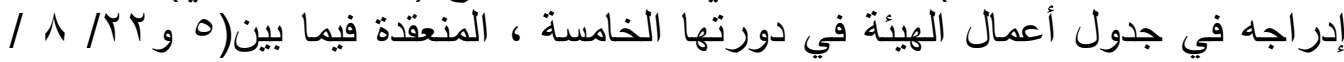

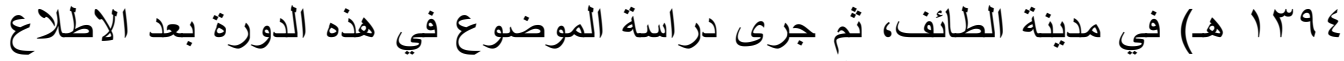

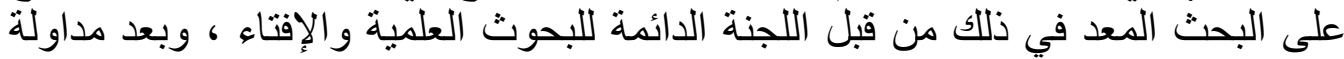

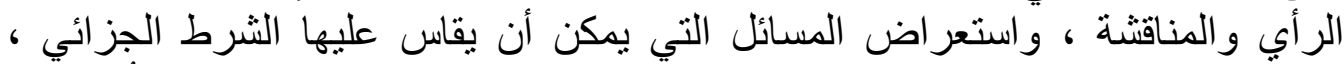

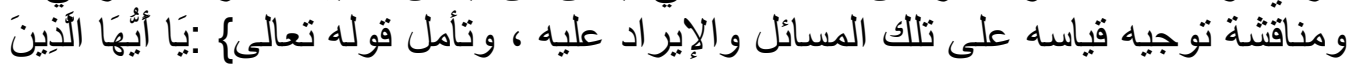

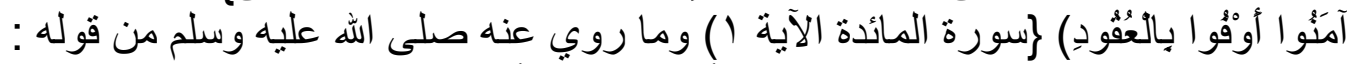

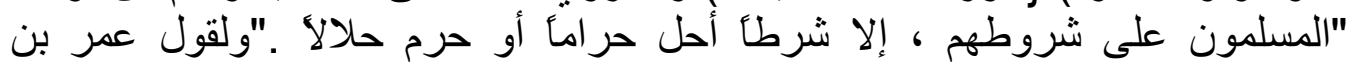

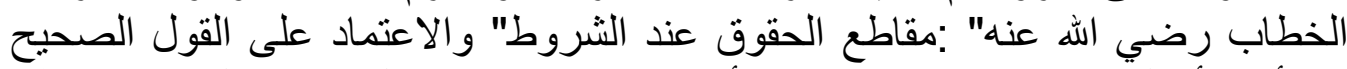

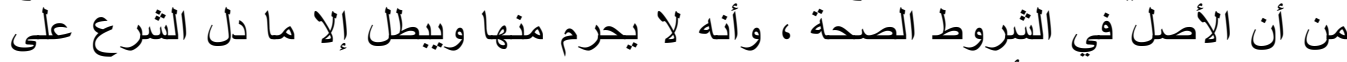
تحريمه و إبطاله نصاً أو فياساً.

واستعر اض ما ذكره أهل العلم من تقسيم الثروط في العقود إلى: صحيحة وفاسدة. وتقسيم الصحيحة إلى ثلاثة أنواع: ألماع

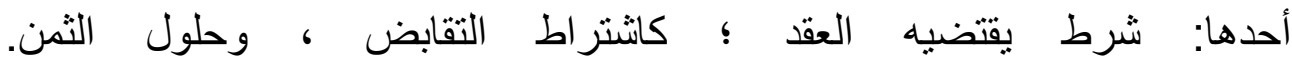

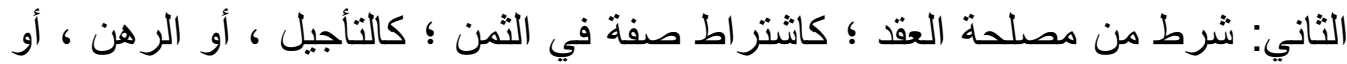
الكفيل به ، أو صفة في المثمن ؛ ككون الأمة بكر آ.

الثالث: شرط فيه منفعة معلومة وليس من مقتضى العقد ولا من مصلحته ، ولا منافيا

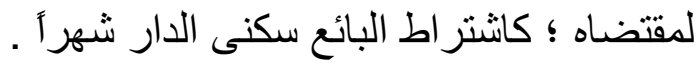
وتقسيم الفاسدة إلى ثلاثة أنواع:

أحدها: اشتر اط أحد طرفي العقد على الطرف الثاني عقدا آخر ؛ كبيع ، أو إجارة ، أو نحو ذلك.

الثاني: اشتر اط ما ينافي مقتضى العقد ؛ كأن يشترط في المبيع ألا خسارة عليه ، أو ألا

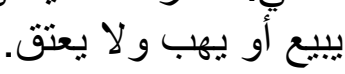
الثالث: الثرط الذي يتعلق به العقد ؛ كقوله: بعتلك إن جاء فلان. 
وبتطبيق الثرط الجزائي عليها ، وظهور أنه من الثروط التي تعتبر من مصلحة العقد ، إذ هو حافز لإكمال العقد في وقته المحدد له ، و الاستئناس بما رواه البخاري في صحيحه بسنده عن ابن سيرين: أن رجلا قال لكريَّه: أدخل ركابك ، فإن لم أرحل معك يوم كذا وكذا فللك مائة درهم فلم يخرج ، فقال شريح: "من شرط على نفسه طائعاً غير مكروه فهو عليه" ـ وقال أيوب عن ابن سيرين: أن رجلا باع طعامأ وقال: إن لم آتك الأربعاء فليس بيني وبينك بيع ، فلم يجئ ، فقال شريح للمشتري: "أنت أخلفت" فقضى عليه. وفضلا عن ذلك فهو في مقابلة الإخلال بالالتزام ، حيث إن الإخلال به مظنة الضرر ، وتفويت المنافع ، وفي القول بتصحيح الشرط الجزائي سد لأبواب الفوضى والتلاعب بحقوق عباد الله ، وسبب من أسباب الحفز على الوفاء بالعهود والعقود تحقيقأ لقوله

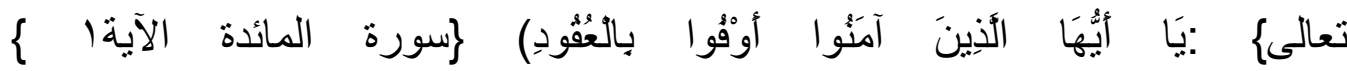
لذلك كله فإن المجلس يقرر بالإجماع :

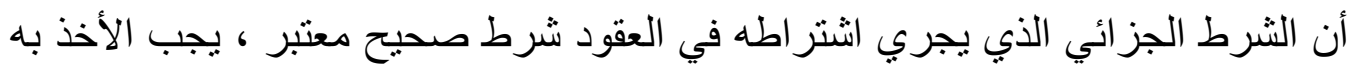

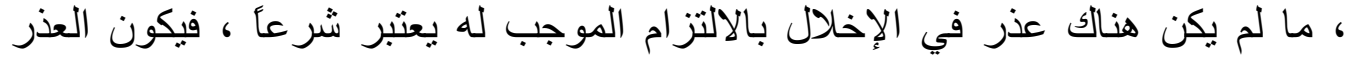

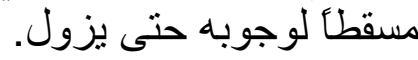

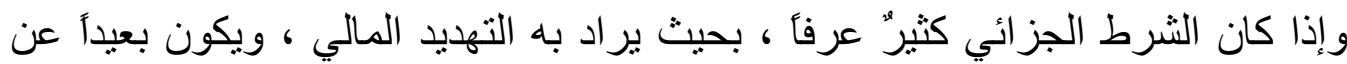

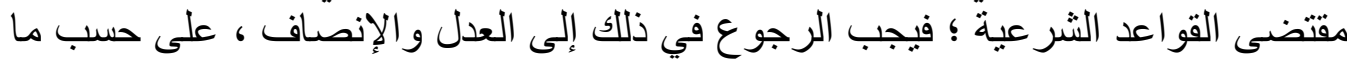
فات من منفعة ، أو لحق من مضرة.

ويرجع تقدير ذلك عند الاختلاف إلى الحاكم الثرعي عن طريق أهل الخبرة والنظر ؛

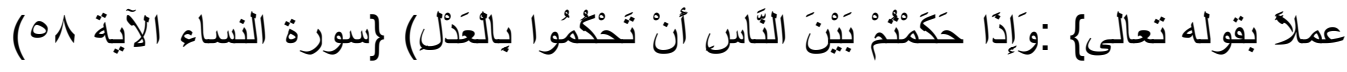

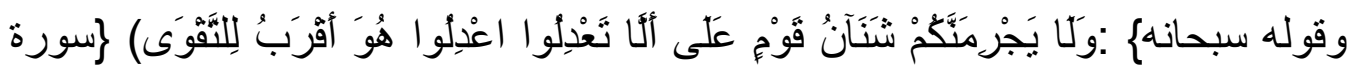
المائدة الآية ^) ، وبقوله صلى الله عليه وسلم" :لا ضرر ولا ضرار. وباله التوفيق ، وصلى الله على محمد، و على آله وصحبه وسلم. 


\section{قرار رقم: 1 ("د/ 11/)}

\section{بـنأز موضو ع}

\section{الثنرط الجزائي}

إن مجلس مجمع الفقه الإسلامي الدولي المنبثق عن منظمة المؤتمر الإسلامي في دورته الإنها

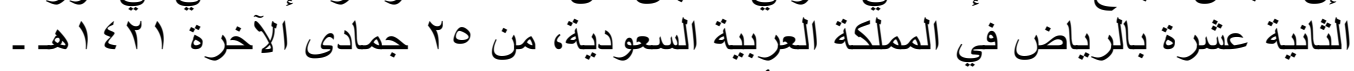

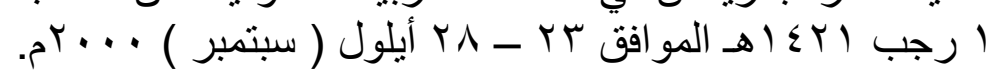

بعد اطلاعه على البحوث الواردة إلى المجمع بخصوص موضوع (الثرط الجزائي).

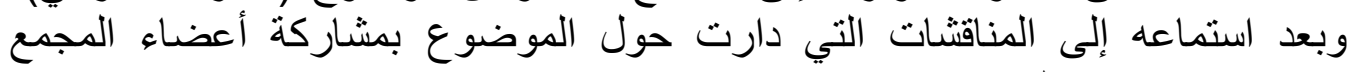
وخبر ائه و عدد من الفقهاء.

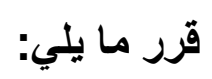

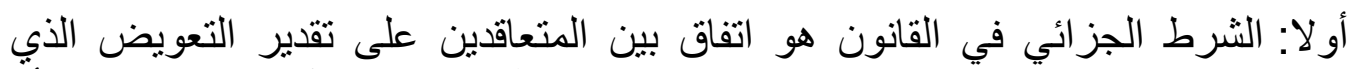

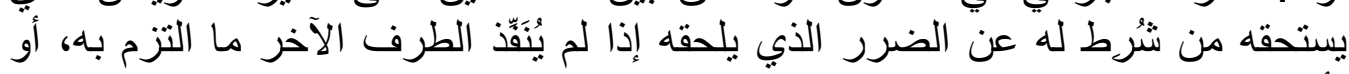
تأخمّر في تنفيذهن.

ثانيا: يؤكد المجلس قراراته السابقة بالنسبة للشرط الجزائي الواردة في قراره في في السَّلم

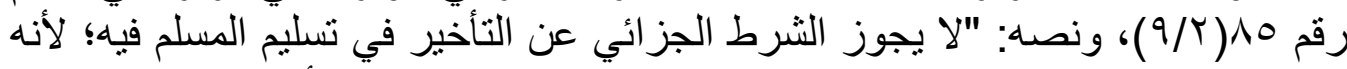

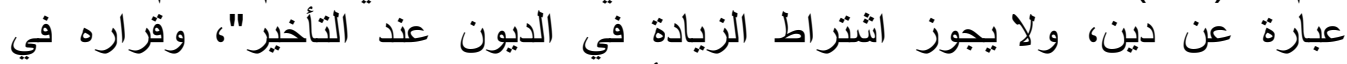
الاستصناع رقم

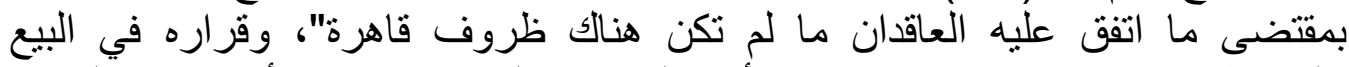

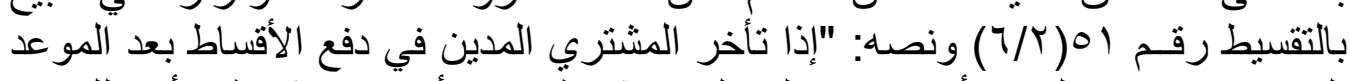

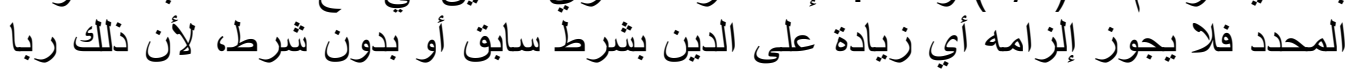

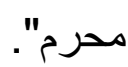

ثالثا: يجوز أن يكون الثرط الجزائي مقترنأ بالعقد الأصلي، كما يجوز أن يكون في اتفاق لاحق قبل حدوث الضكرن الثرط النز

رابعا: يجوز أن يشترط الثرط الجزائي في جميع العقود المالية ما عدا العقود التي يكون الالتز ام الأصلي فيها دينأ؛ فإن هذا من الرباً الصريح.

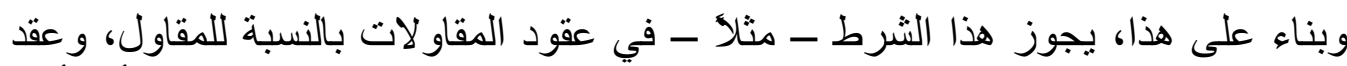

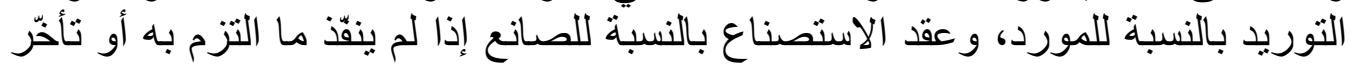
في تنفيذه. 
ولا يجوز - مثلا - في الييع بالتقسيط بسبب تأخر المدين عن سداد الأقساط المتبقية

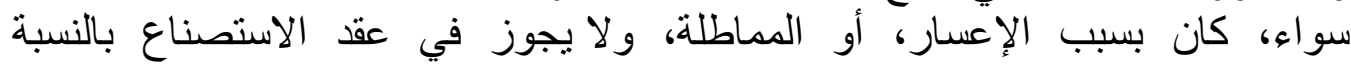
اللمستصنع إذا تأخر في أداء ما عليه.

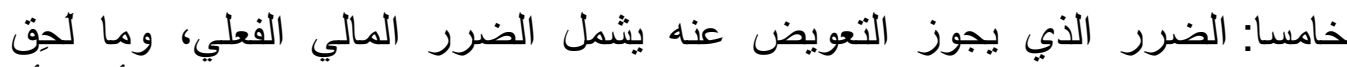
المضرور من خسارة حقبقية، وما فاته من كسب مؤكد، ولا يثمل الضرر الأدبي أو لون

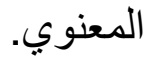

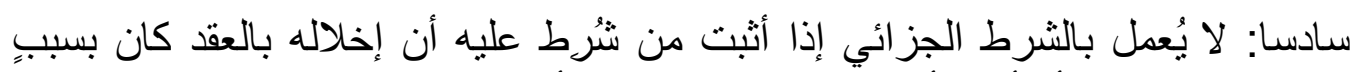

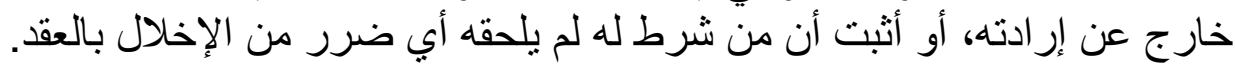

سابعا: يجوز للمحكمة بناء على طلب أحد الطرفين أن ثُعدّل في مقدار التعويض إذا وجدت مبررأ لذلك، أو كان مبالغأ فيه. ويوصي المجمع بما يلي: - مئي

بعقد ندوة متخصصة لبحث الثروط و التدابير التي تقترح للمصارف الإسلامية لضمان حصولها على الديون المستحقة لها.

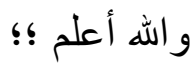




\section{المعيار الشر عي رقم ("F)}

\section{المدين المماطل}

\section{نم المعيار}

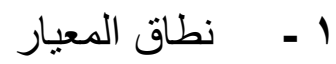

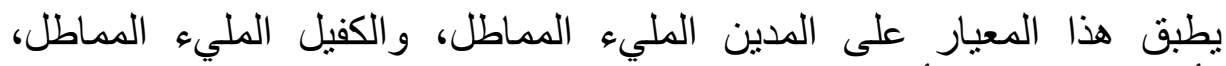
و المقاول أو المتعهد الذي يتأخر عن تنفيذ العمل فيصير مدينأ بمقتضى الثرط الجزئ الئي. ولا بطبق المعيار على المدين المعسر أو المفلس، والمدين المتأخر عن سداد الدين لعذر شرعي.

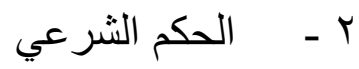

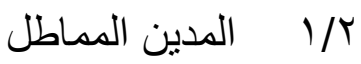
تحرم مماطلة المدين القادر على وفاء الدين.

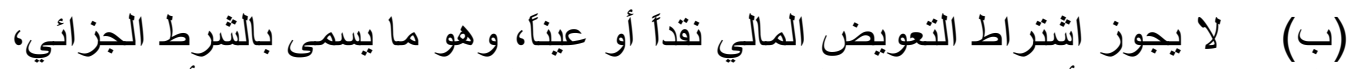

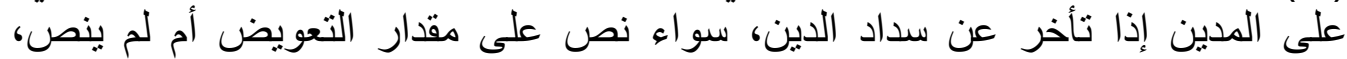
وسواء كان التعويض عن الكسب الفائت (الفرصة الضائعة) أم عن تغير قيمة العملة .

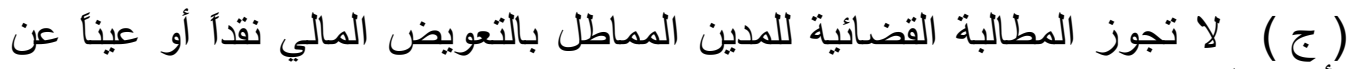
تأخير الدين. ( ) يتحمل المدين المماطل مصروفات الدعوى وغيرها من المصروفات التي غرمها الدائن من أجل تحصيل أصل دينه.

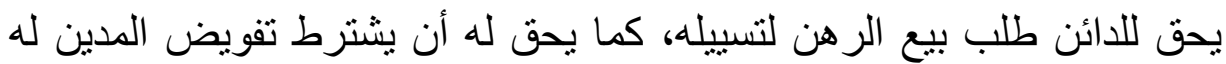

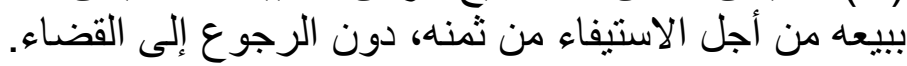

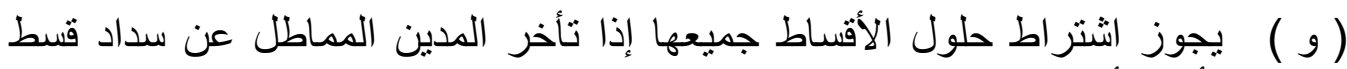
منها. و الأولى أن لا يطبق هذا الشرط إلا بعد إثعار المدين ومضي مدة مناسبة لا لأنق عن أسبو عين.

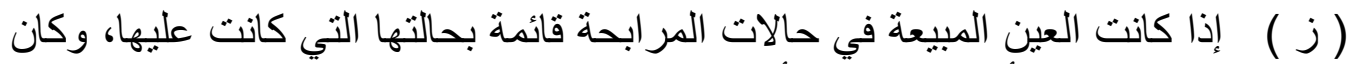

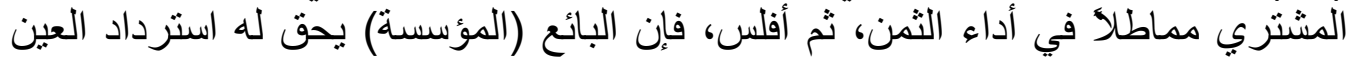

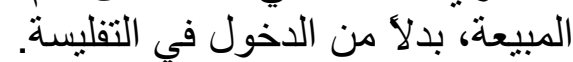




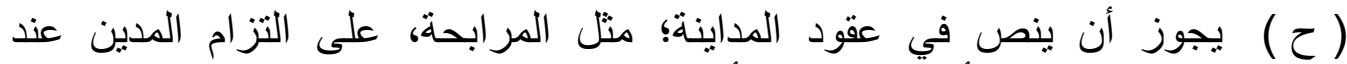

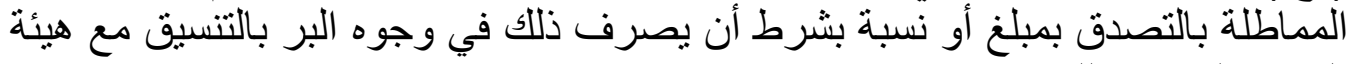
الرقابة الثر عية للمؤسسة. 


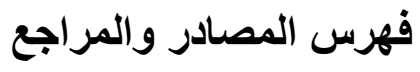

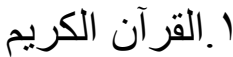

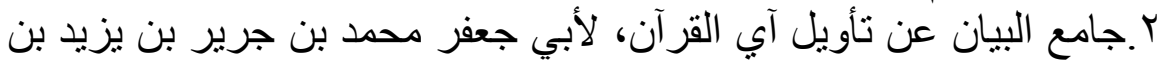

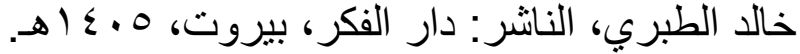

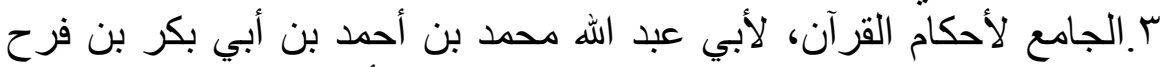

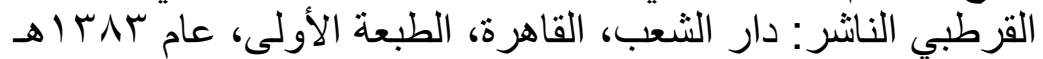

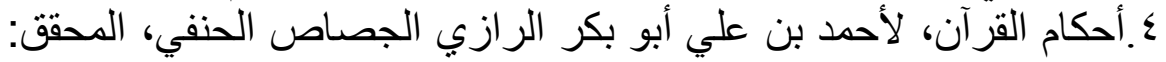

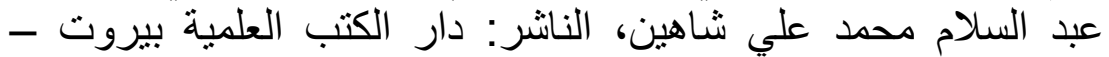

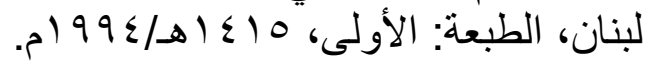

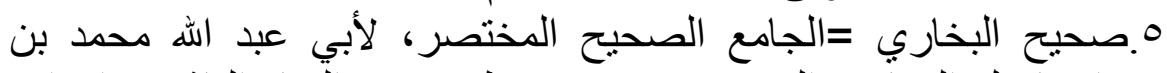

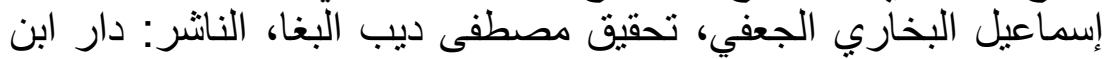

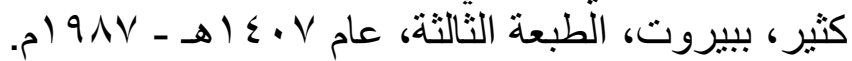

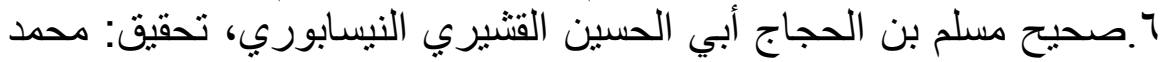

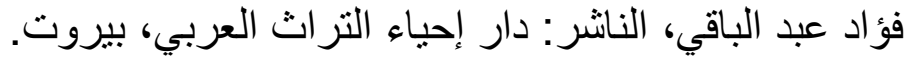

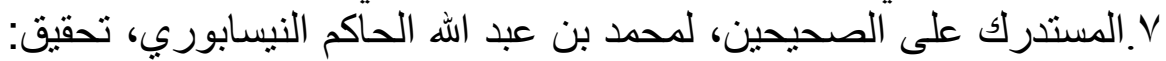

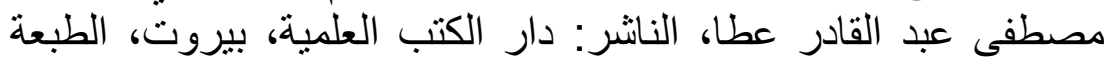

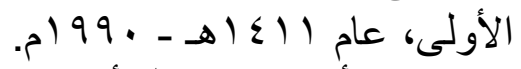

^.مسند الإمام أحمد بن حنبل أبي عبد الله الثيباني، الناشر: مؤسسة قرطبة، القاهرة. - ميند الإمام 9.صحيح ابن حبان بترتيب ابن بلبان، لمحمد بن حبان بن أحمد أبي حاتم

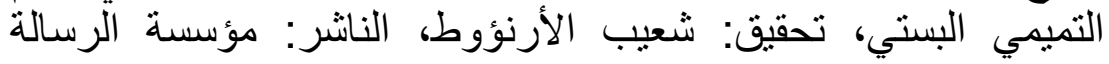

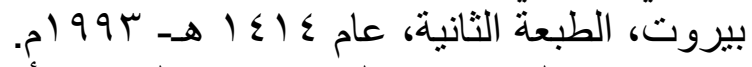
•

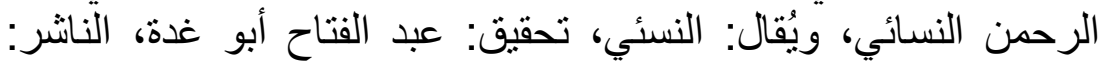

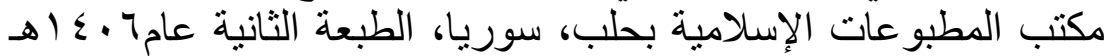
. 917 11. سنن ابن ماجه، لمحمد بن يزيد أبي عبد الله القزويني، تحقيق: محمد فؤاد عبد الباقي، الناشر: دار الفكر بيني، لبيروت، ومع الكتاب: تعليق محمد فؤاد عبد الباقي.

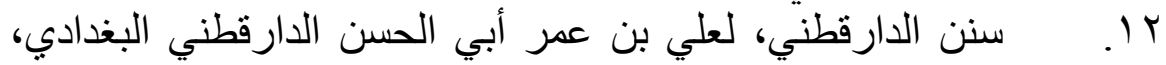

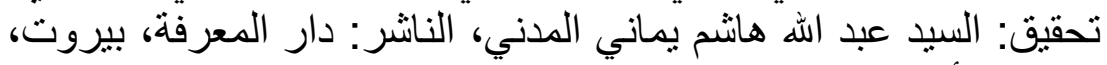

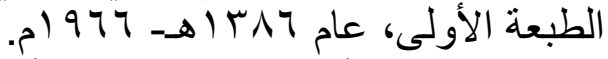

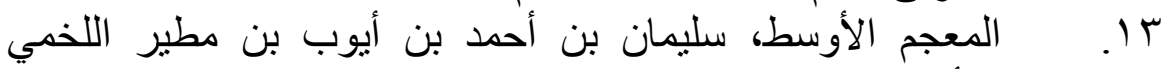

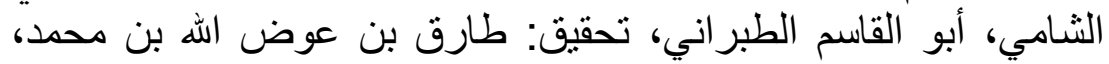

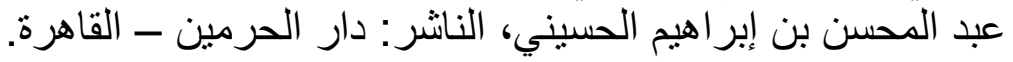




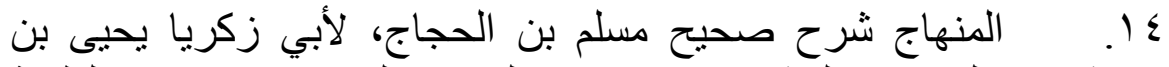

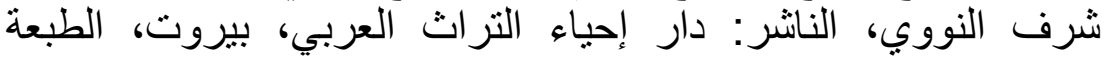

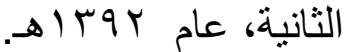

10. صحيح الجامع الصغير وزيادانه، لأبي عبد الرحمن محمد ناصر الدين، بن الحاج نوح بن نجاتي بن آدم، الأشقودري الألباني، النانثر:

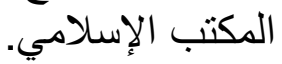

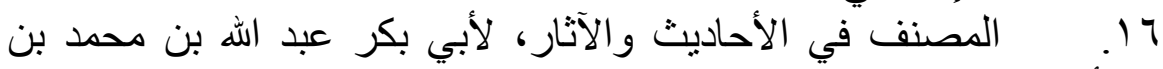

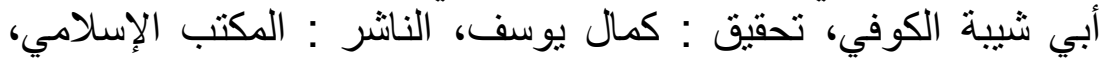

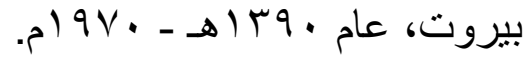

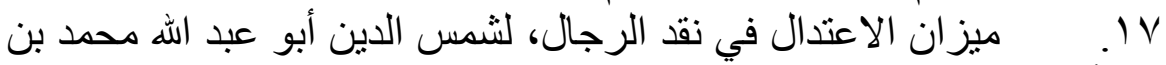

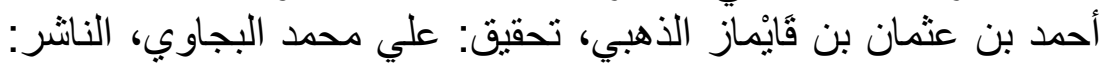

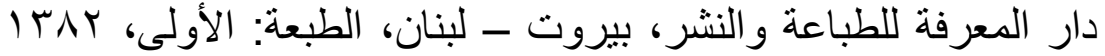

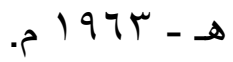

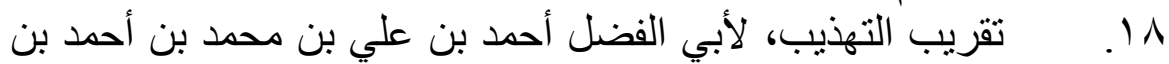

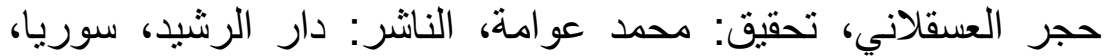

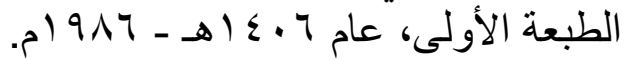

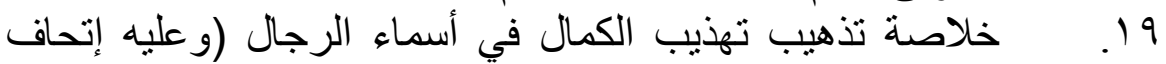

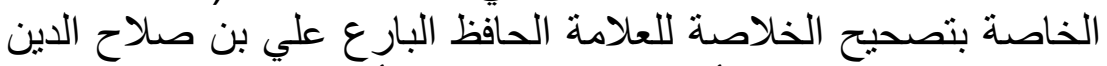

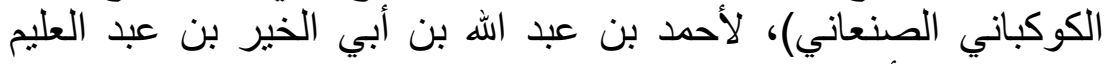

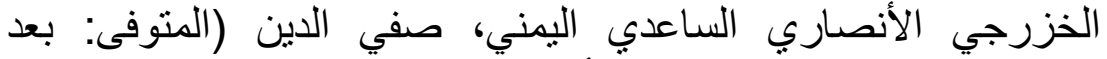

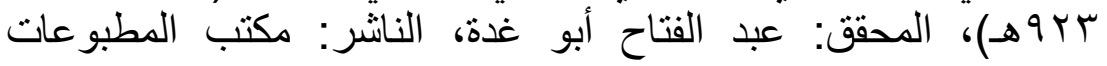

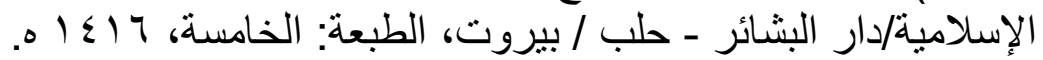

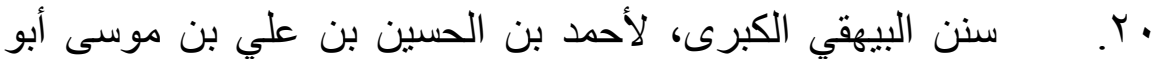

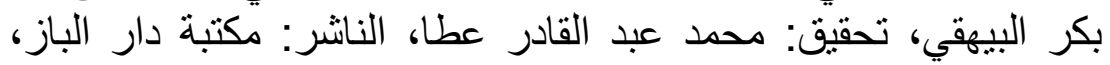

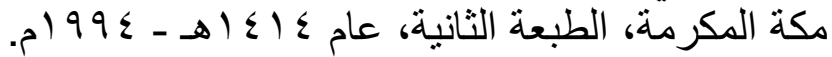

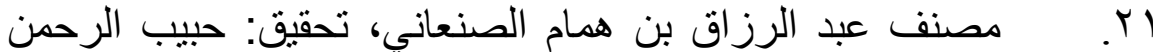
الأعظمي، الناثر: الدكتب الإسلامي، بيروت، الطبعة الثانية، عام الرحن

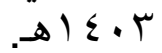

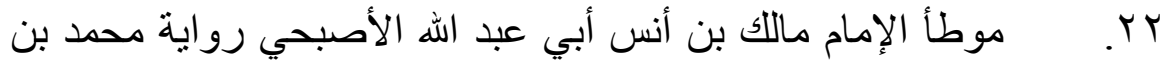

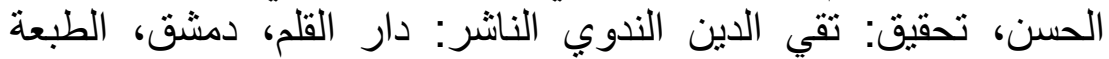

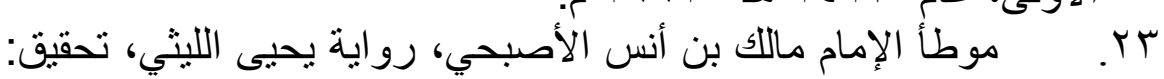

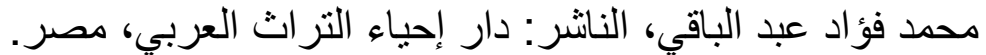

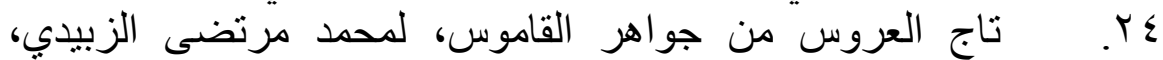

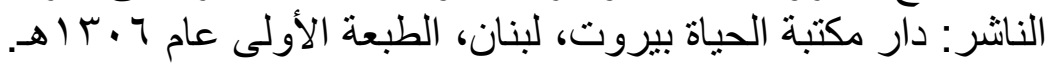

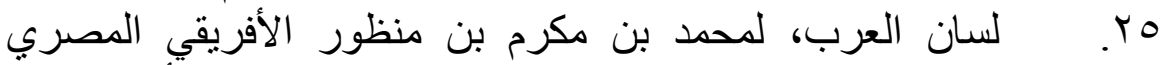
المشهور بابن منظور، النانثر: دار صادر، بيروت، الطبعة الأولى. 
דr. مقاييس اللغة، لأبي الحسين أحمد بن فارس بن زكريا، تحقيق: عبد السلام محمد هارون، الناشر: دار الجيل، بيروت، لبنان، الطبن الطبعة

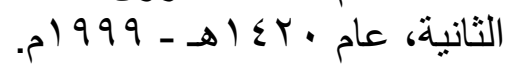

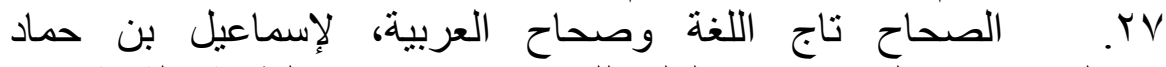

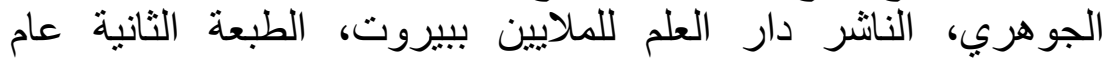

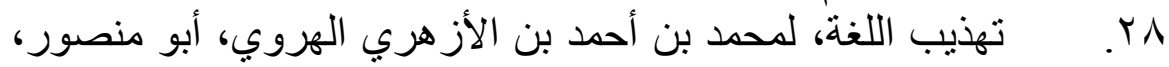

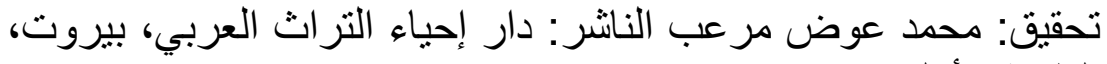

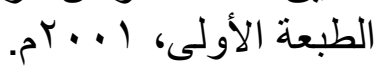

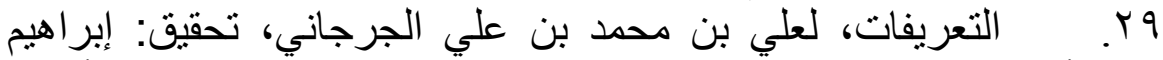

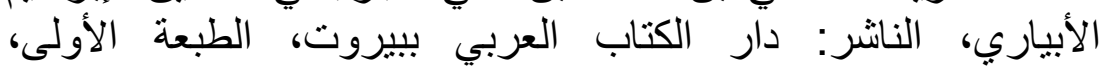

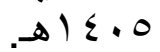

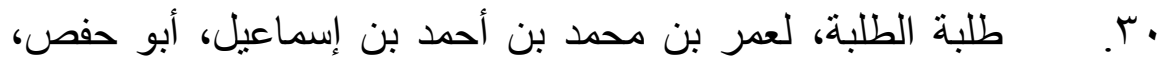

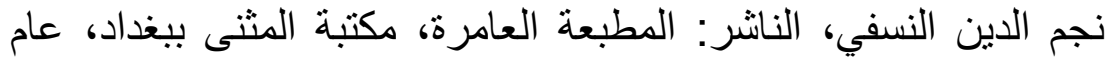

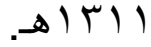

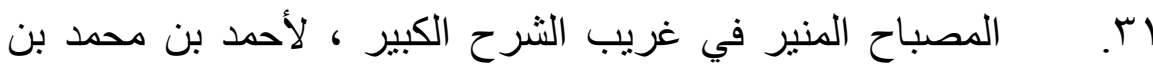

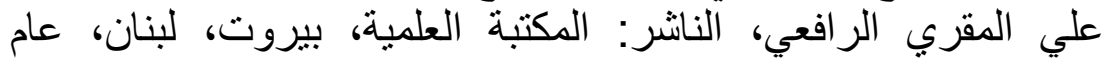

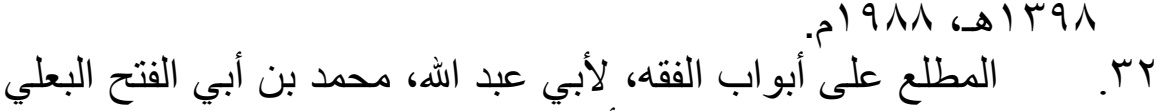

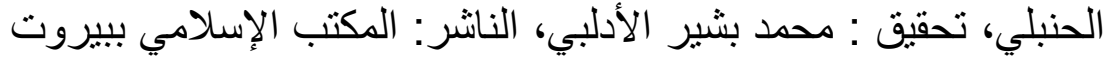

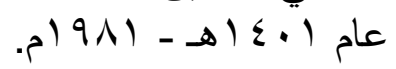
rr. النهاية في غريب الحديث والأثر، لمجد الدين أبو السعادات

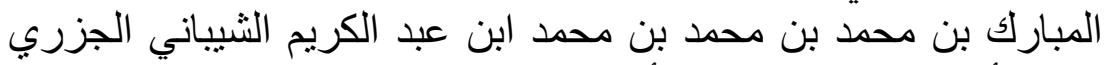

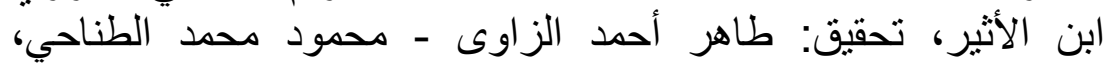

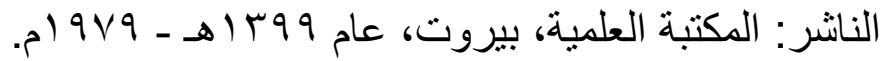

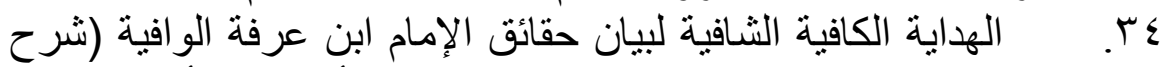

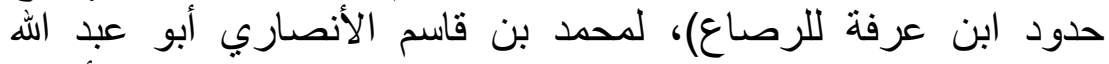

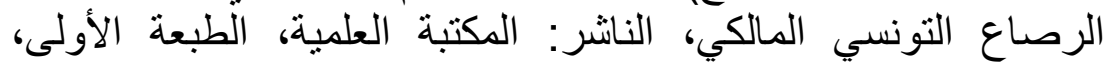

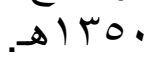

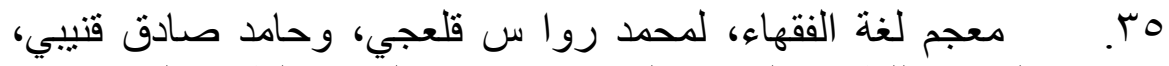
دار النفائس للطبع والنشر والتوزيع، بيروت لبنان، الطبعة الثانية، عام

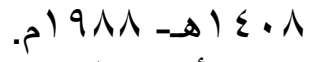

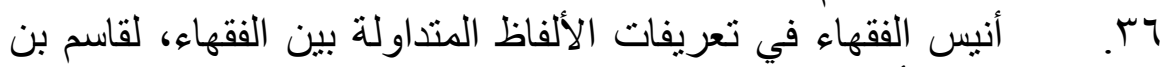

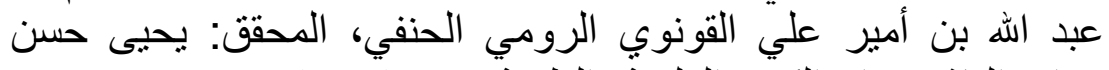

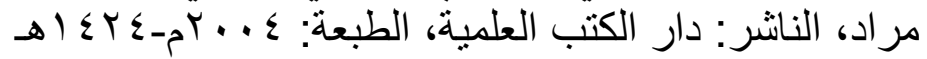

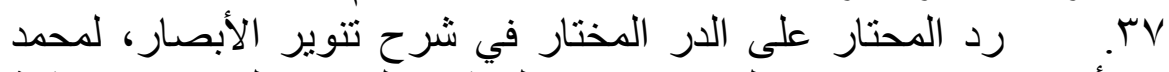

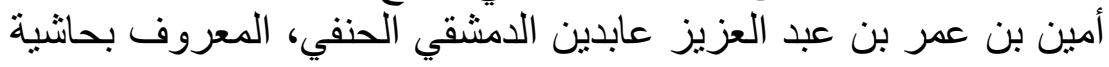


ابن عابدين، الناشر: دار الفكر، بيروت، الطبعة الثانية، عام با إ اهـ ـ الم 994

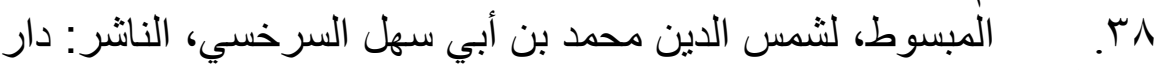
المعرفة، لبنان، بيروت.

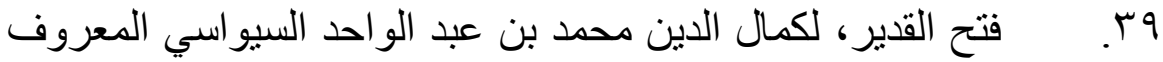

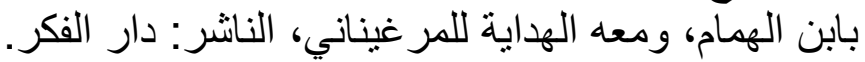

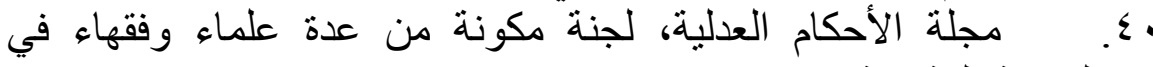
الخلافة العثمانية

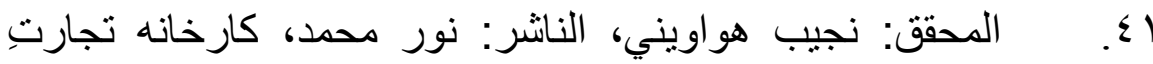
كتب، آرام باغ، كرانتي التهي

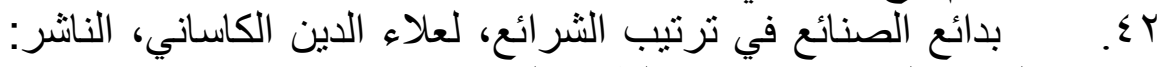

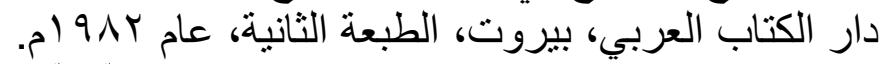

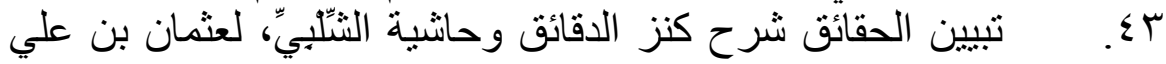

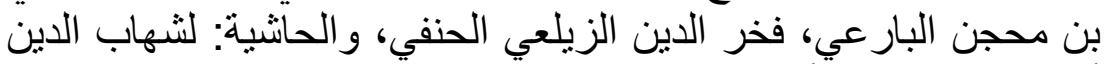

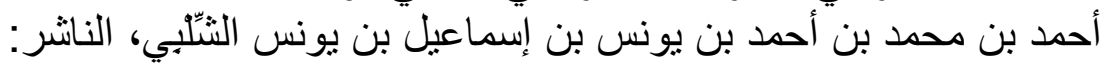

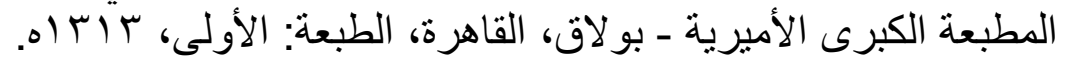

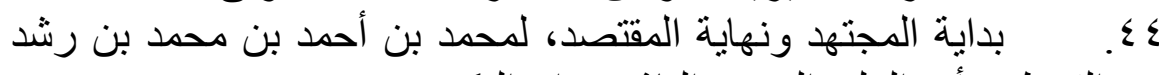

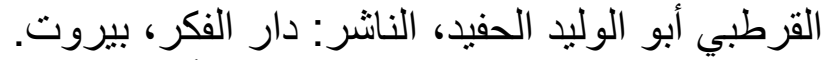

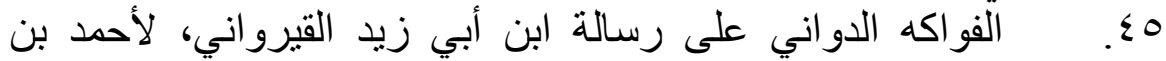

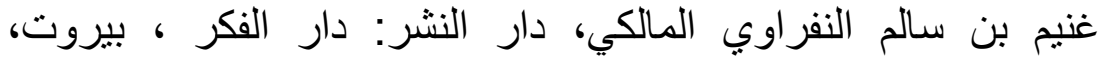
إ 10

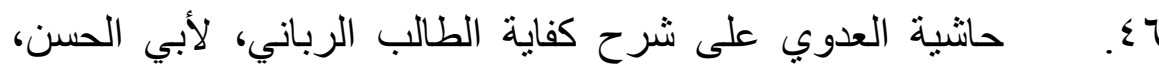

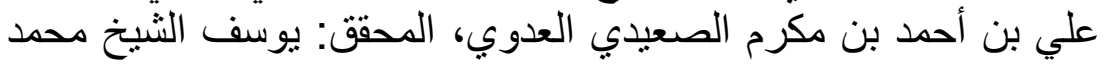

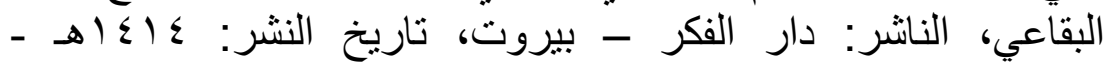
ـ

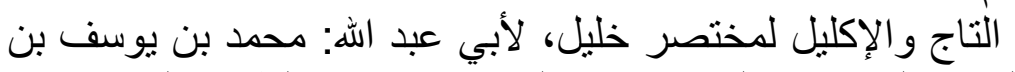

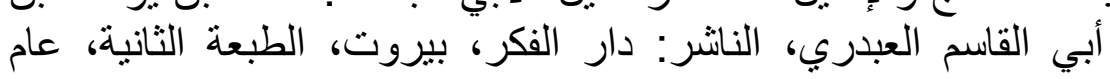

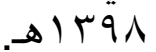

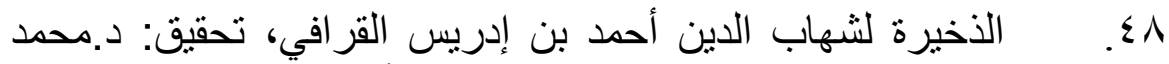

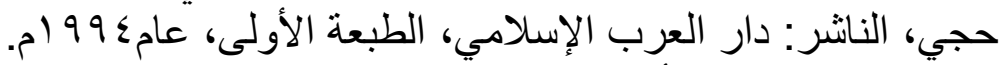

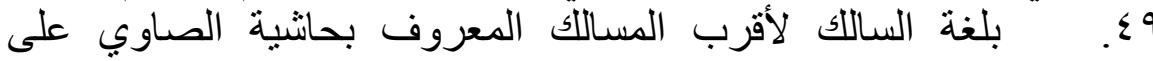

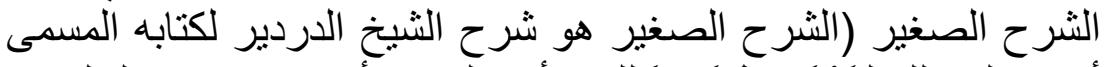

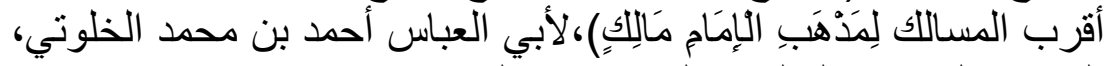

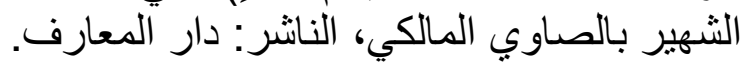

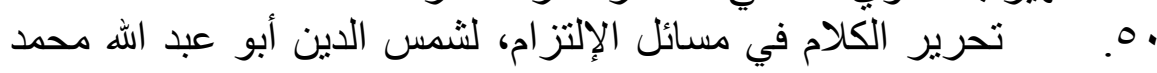

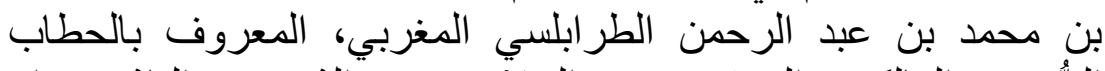

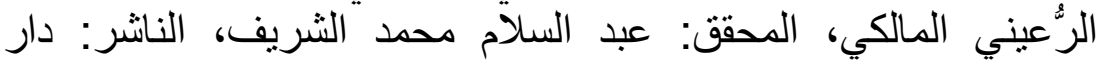


الغرب الإسلامي، بيروت ـ لبنان، الطبعة: الأولى، ع ــ 1 هـ - عـ19

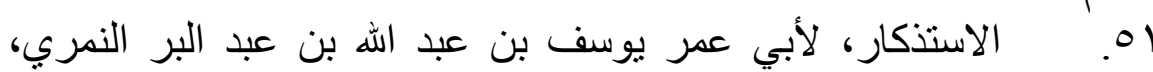

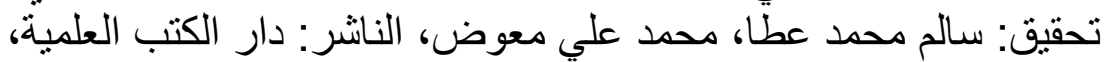

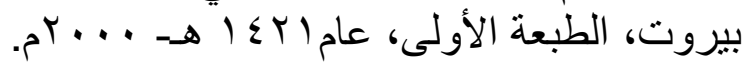

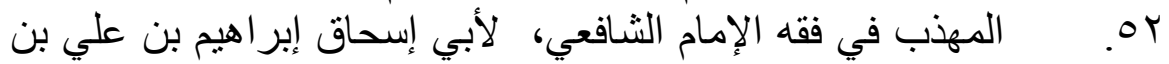

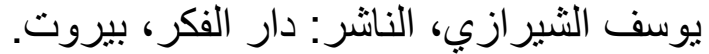

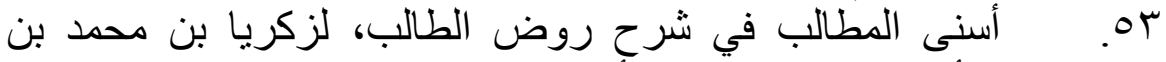

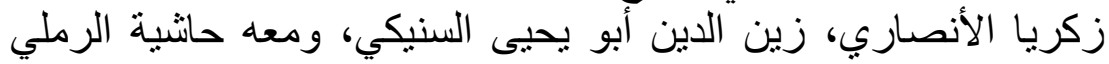

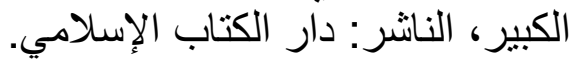

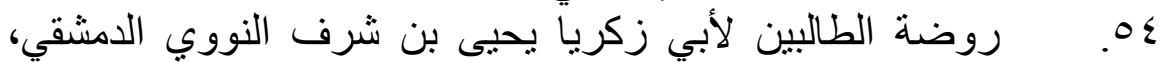

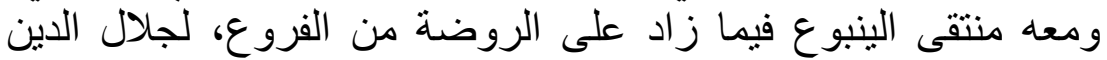

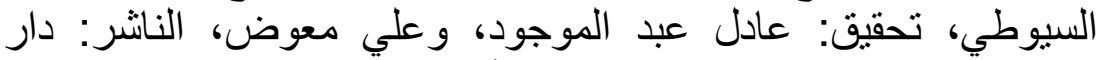

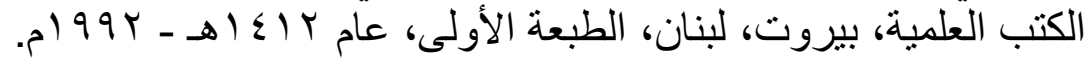

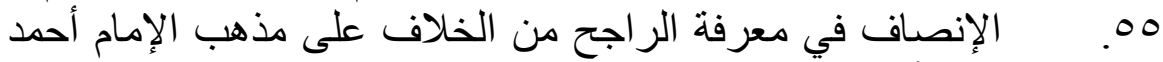

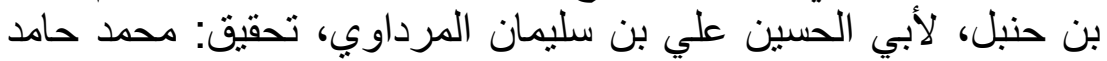

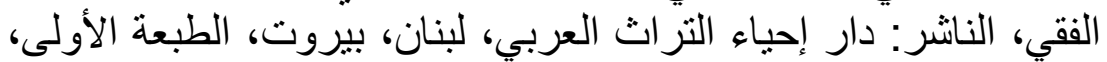

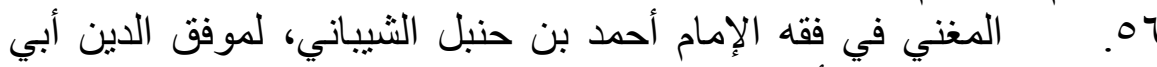

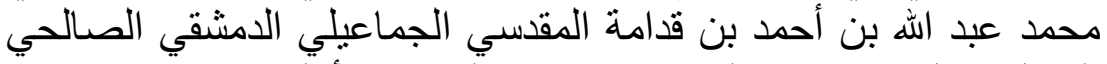

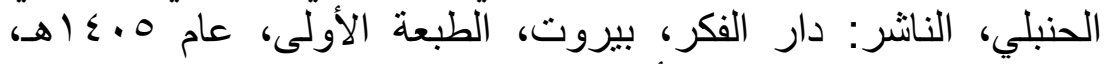

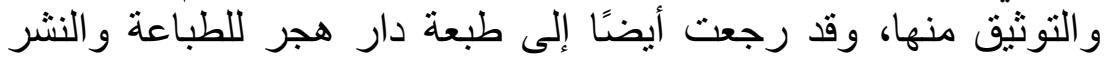

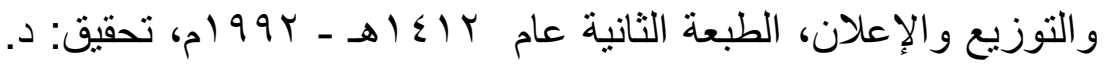

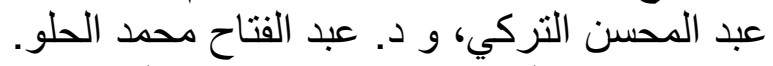
oV

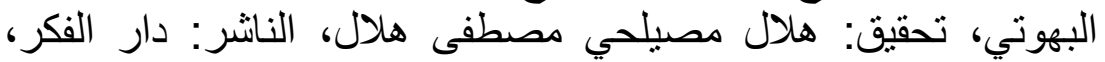

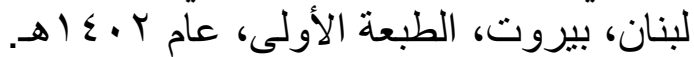

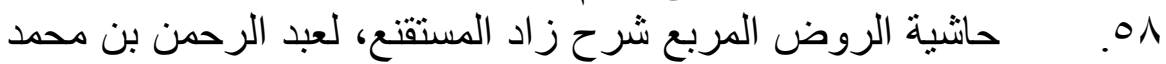

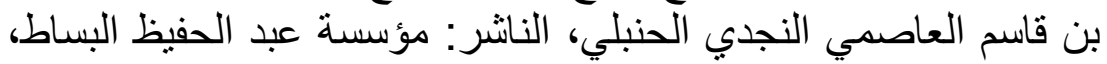

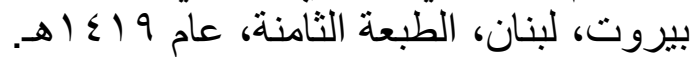

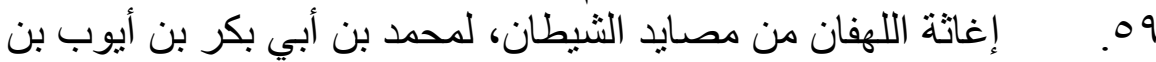

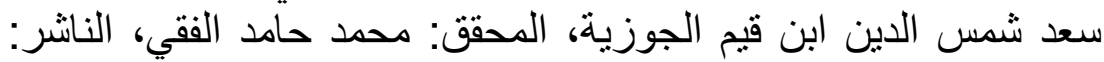
مكتبة المعارف، الرياض، المملكة العربية السعودية.

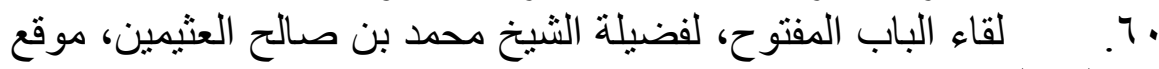

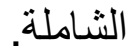
آ. الزمن في الديون وأحكامه الفقهية لفضيلة الثيخ سعد الختلان، بحث منشور على موقع فضيلته. 
rT. أحكام الزيادة في غير العبادات، لمحمد العيد، الناثر: مطابع

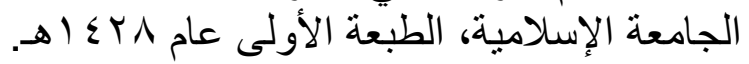

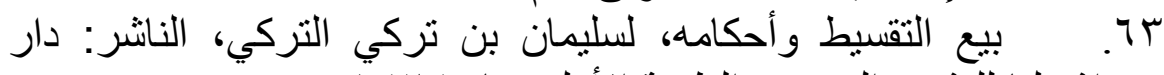

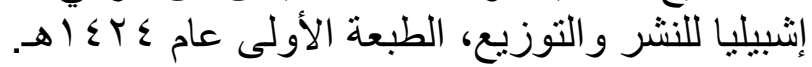

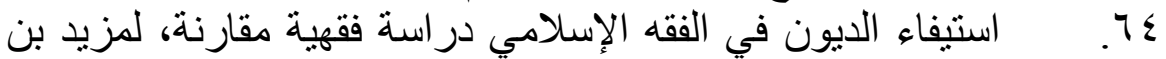

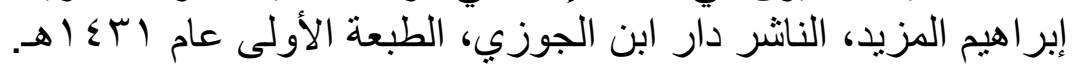

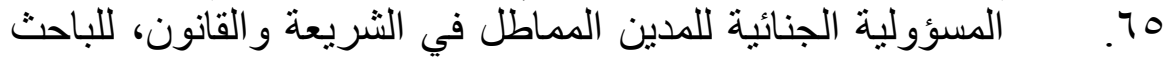

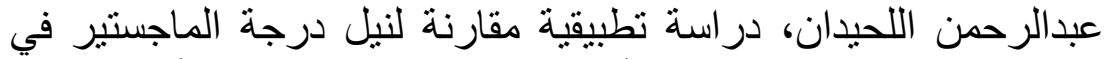

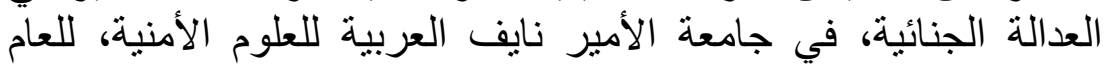
Tـ

77 7 البيع المؤجل، للاكتور عبدالستار أبو غدة، سلسلة محاضرات

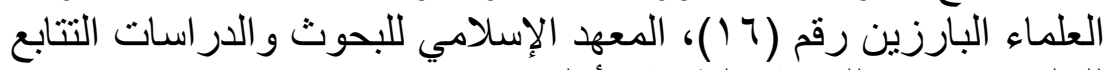

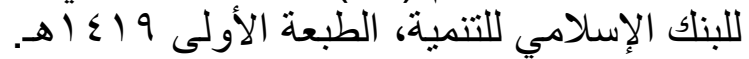

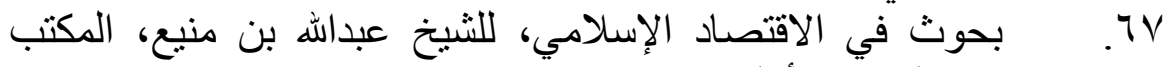

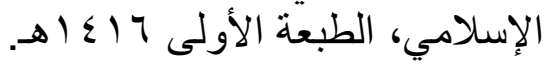

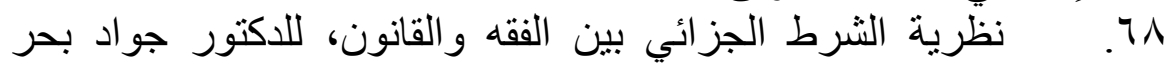

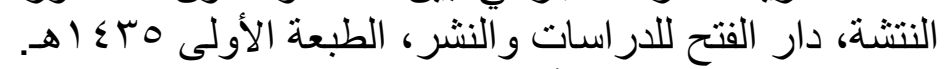

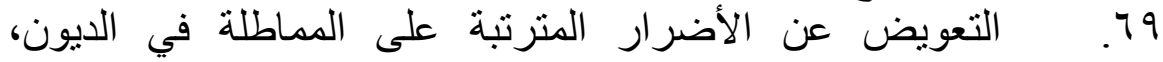

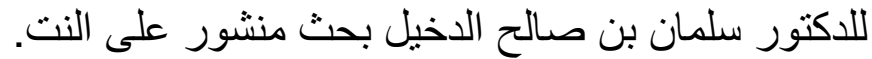

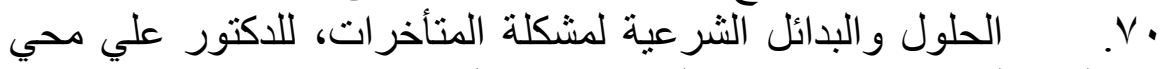
الدين القره، بحث منشور على موقع فضيلته.

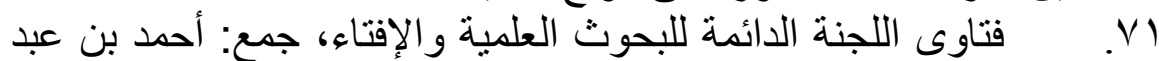

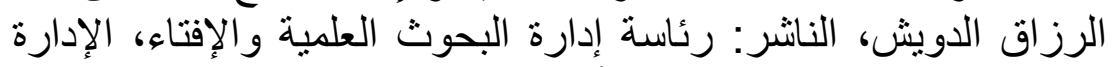

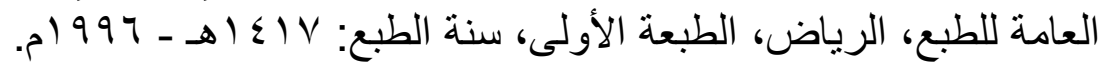

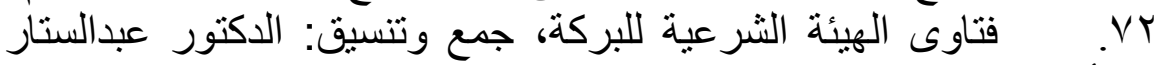

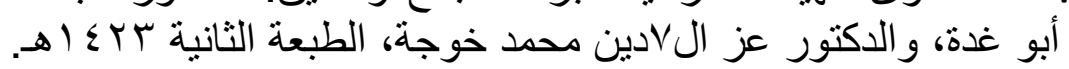

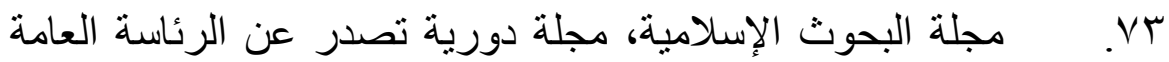

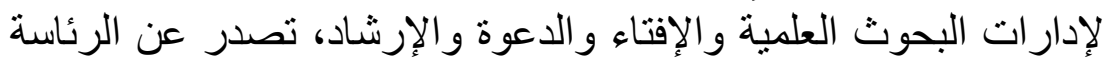

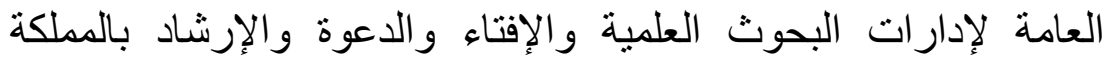
العربية السعودية. V

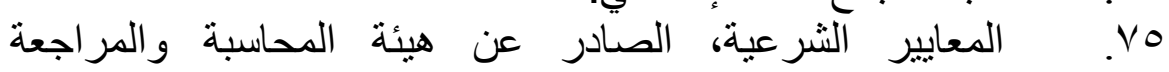

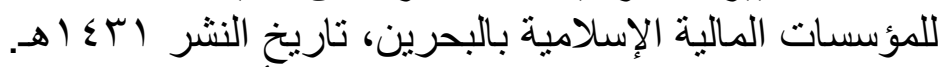

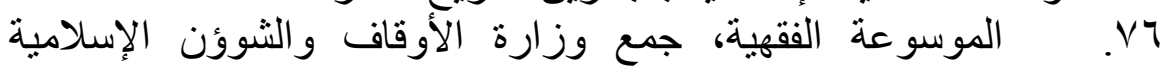

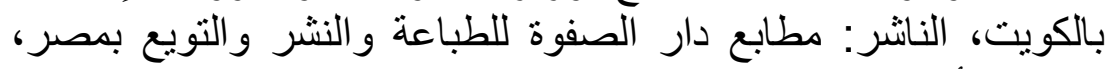

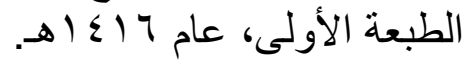

